Portland State University

PDXScholar

Summer 7-24-2015

\title{
Characterization, DNA Binding and Cleavage Activities of New Prodigiosin and Tambjamine Analogues and Their $\mathrm{Cu}^{2+}$ and $\mathrm{Zn}^{2+}$ Complexes
}

Karen Chichetu

Portland State University

Follow this and additional works at: https://pdxscholar.library.pdx.edu/open_access_etds

Part of the Medicinal-Pharmaceutical Chemistry Commons, and the Organic Chemistry Commons Let us know how access to this document benefits you.

\section{Recommended Citation}

Chichetu, Karen, "Characterization, DNA Binding and Cleavage Activities of New Prodigiosin and Tambjamine Analogues and Their $\mathrm{Cu}^{2+}$ and $\mathrm{Zn}^{2+}$ Complexes" (2015). Dissertations and Theses. Paper 2467.

https://doi.org/10.15760/etd.2465

This Dissertation is brought to you for free and open access. It has been accepted for inclusion in Dissertations and Theses by an authorized administrator of PDXScholar. Please contact us if we can make this document more accessible: pdxscholar@pdx.edu. 
Characterization, DNA Binding and Cleavage Activities of New Prodigiosin and Tambjamine Analogues and Their $\mathrm{Cu}^{2+}$ and $\mathrm{Zn}^{2+}$ Complexes

\author{
by \\ Karen Chichetu
}

A dissertation submitted in partial fulfillment of the requirements for the degree of

\author{
Doctor of Philosophy \\ in \\ Chemistry
}

Dissertation Committee:

Kevin Reynolds, Chair Jon Abramson

Niles Lehman

David Peyton

Portland State University

2015 
(C) 2015 Karen Chichetu 


\section{Abstract}

Prodigiosins and tambjamines are natural compounds from bacterial and marine sources belonging to a family containing a common 4-methoxy-2,2'-bipyrrole core. These compounds have received a lot of interest due to their promising biological activities. Studies have suggested DNA as a potential therapeutic target for the natural prodigiosin and tambjamine due to their ability to facilitate oxidative DNA cleavage in the presence of $\mathrm{Cu}^{2+}$. Based on this we sought to study the metal binding activity of new prodigiosin and tambjamine analogues. A new prodigiosin analogue was synthesized and complexed with $\mathrm{Cu}^{2+}$. This revealed 1:1 complex formation between the tripyrrole and $\mathrm{Cu}^{2+}$ that was confirmed by mass spectra and NMR spectra analysis. In addition in situ studies also revealed that our new analogues of prodigiosin cannot bind $\mathrm{Zn}^{2+}$ when the methoxy group on ring $\mathrm{B}$ is replaced by an alkyl group or when one of the ring nitrogens is methylated.

Our UV-Vis experiments with calf thymus DNA showed that prodigiosins and tambjamines bind DNA mainly through an external mode, suggesting that hydrogen bonding between the pyrrole ring nitrogens and the bases of DNA takes precedence over stacking interactions. For the new $\mathrm{Cu}^{2+}$ complex synthesized however, we observed spectral changes that suggest intercalation into DNA.

DNA cleavage experiments revealed that the prodigiosin-Cu complex is able to convert supercoiled DNA into its linear form. The data from the gel shift assays fit well to a first-order consecutive reaction model. In addition to preformed metal complexes, we showed DNA cleavage by in situ complexation of the ligands in the 
presence of $\mathrm{Cu}^{2+}$. However, although we showed $\mathrm{Zn}^{2+}$ complex formation with prodigiosin analogues, in situ studies did not show induction of DNA cleavage by $\mathrm{Zn}^{2+}$ complexes under our experimental conditions. 


\section{Dedication}

To my grandpas, William Sakala and Geoffrey Matambanadzo for always believing in me 


\section{Acknowledgments}

I would like to thank my advisor Dr. Kevin Reynolds, for his patience, enthusiasm, encouragement, and always making time to be there. I am also greatly indebted to my committee members; Dr. Niles Lehman, Dr. David Peyton and Dr. Jon Abramson for giving their time and valuable feedback which helped shaped the work in this dissertation. Special thanks to Dr. Niles Lehman for training me on the use of the Typhoon imager and giving me unrestricted access to the instrument.

I am grateful to the Chemistry department for the support and resources made available to me during the course of my studies especially; Joan, Lisa and Tam for always being there when I needed help.

To past and present members of KARLab; you guys are my second family and I

am thankful that you were there to be my brothers, sisters and occasionally therapists, keeping me sane when the research was not going according to plan.

I would like to thank my family and friends especially; my mother, Marianne; dad, Samuel and my siblings; Maureen, William and Rodney for the love and support that was sent across the miles.

And finally to my husband, Lenon, whose patience, love, emotional and financial support is the reason I am where I am today; and to my daughter and my everything, Kayleigh, thank you for being you and for always putting a smile on my face. 


\section{Table of Contents}

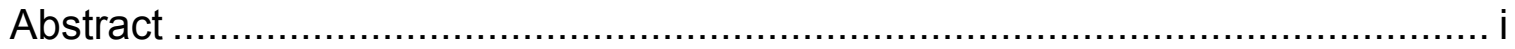

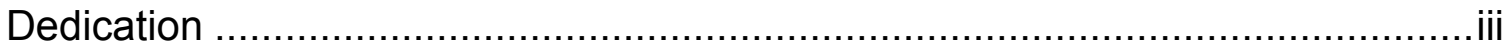

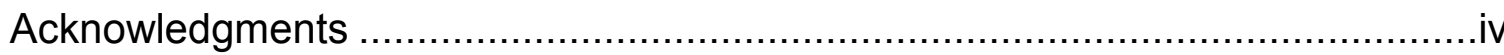

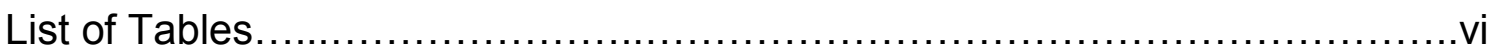

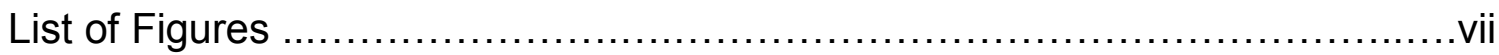

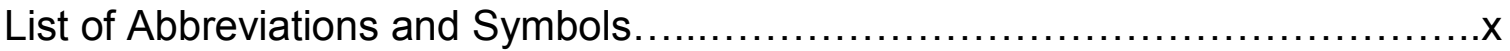

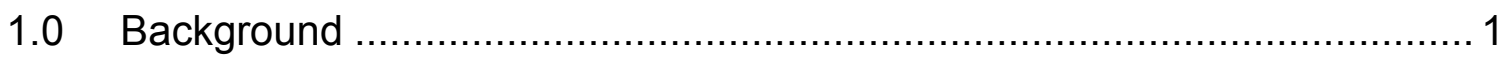

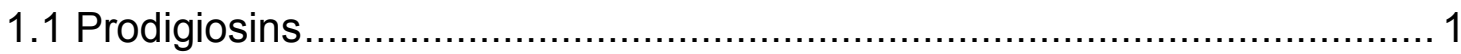

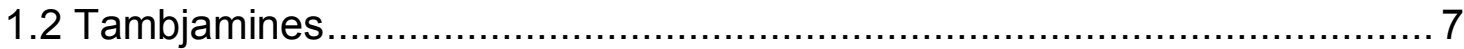

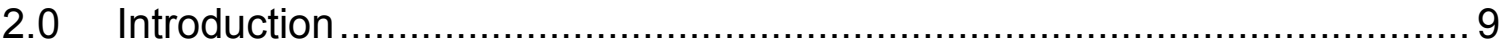

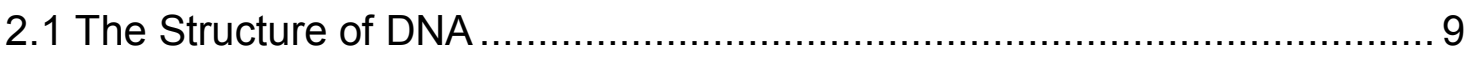

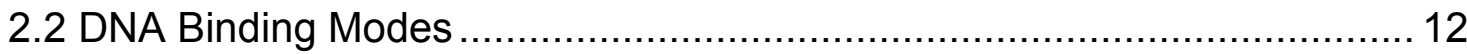

2.3 Supercoiled DNA and Small Molecule Interactions ............................... 15

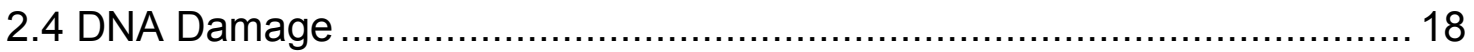

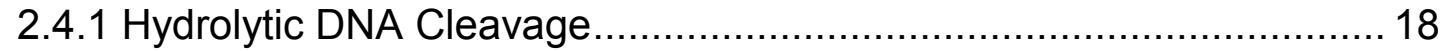

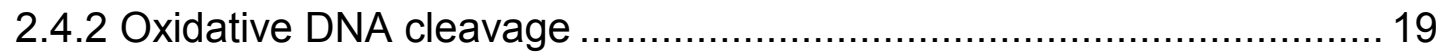

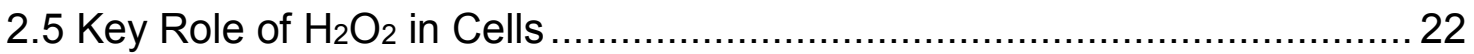

2.6 Copper and Zinc in Biological Systems ............................................... 23

2.7 Specific Aims of This Proposal .............................................................. 26

3.0 Characterization, DNA Binding and Cleavage Activity of a new

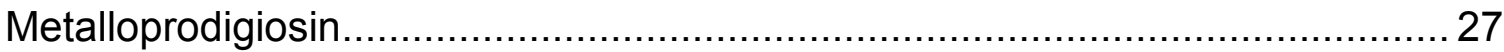

4.0 In situ Studies of $\mathrm{Cu}^{2+}$ and $\mathrm{Zn}^{2+}$ Complexes of Prodiginine and Tambjamine Analogues; DNA Binding and Cleavage Activity.........................50

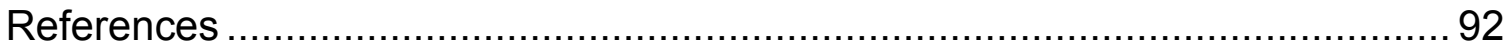




\section{List of Tables}

Table 1. Experimental $p K_{a}$ Values of Prodigiosin and Tamjamine Analogues.... 56 Table 2: Summary of Observed UV-Vis Spectral Changes of Prodigiosin and Tambjamine Analogues in the Presence of CT DNA ..................................... 75

Table 3. Rate Constants of DNA Linearization.............................................. 87 


\section{List of Figures}

Figure 1. Canonical Structure and Isomeric Forms of Prodigiosin. .................. 2

Figure 2. Some Members of the Natural Prodigiosin Family ............................. 3

Figure 3. Synthesis and Possible Applications of Prodigiosins......................... 4

Figure 4. Some of the Cellular Processes Affected by Prodiginines................... 6

Figure 5. Structures of Tambjamines A-C...................................................... 7

Figure 6. DNA Occurs in the Nucleus Packed Into Chromosomes................... 10

Figure 7. Features of Regular Helical Structures Of A, B, C and Z DNA ......... 11

Figure 8. Binding Modes of Small Molecules to DNA................................... 13

Figure 9. Structures of Some Intercalators and Groove Binders...................... 16

Figure 10. Some Metal Complexes that have Clinical Uses. ........................... 17

Figure 11. Proposed Mechanism for the Hydrolytic Cleavage of DNA.............. 18

Figure 12. Reactive Oxygen Species Production in the Mitochondria .............. 19

Figure 13. Reactive Oxygen Species and Oxidative Stress in Cells................. 20

Figure 14. The Hydroxyl Radical Reacts With DNA Bases............................. 21

Figure 15. Some DNA Base Damage Products Resulting From Reactive Oxygen

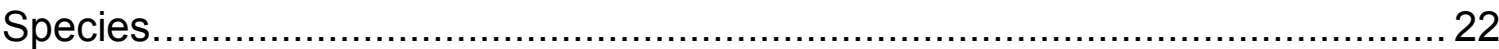

Figure 16. Pathways for Generation of ROS Production and Detoxification..... 23

Figure 17. Oxidative Cleavage by C-3' Abstraction of Deoxyribose .................. 25

Figure 18. Structure of Prodigiosin, a Prodigiosin $\cdot \mathrm{Cu}$ Complex and New

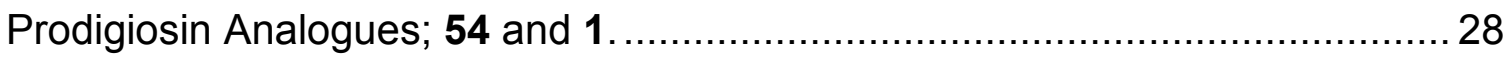

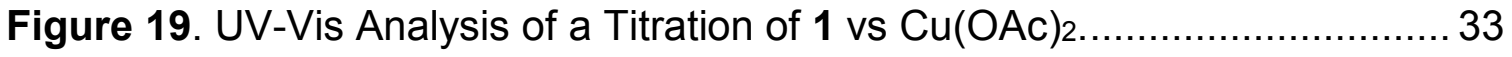

Figure 20. The Color Change Observed When $\mathrm{Cu}(\mathrm{OAc})_{2}$ is Added to a Solution of 1. ESI-MS Analysis Of 1. Cu Complex Formation in $90 \% \mathrm{MeOH}$ Solution...... 34

Figure 21. UV-Vis Profile Of 1 and $\mathbf{1} \cdot \mathbf{C u}$ and TLC Characterization Of 1 and

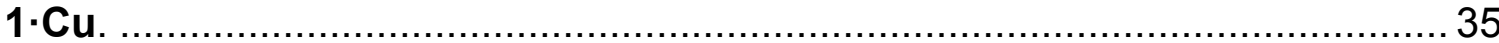

Figure 22. ESI-MS Analysis of 1.Cu Complex and a Comparison of the MS Isotope Patterns on 1·Cu With Isotope Simulation.......................................... 36

Figure 23. ${ }^{1} \mathrm{H}$ NMR Spectral $\left(400 \mathrm{MHz}, \mathrm{CDCl}_{3}\right)$ Analysis.............................. 38 
Figure 24. Spectral Changes Observed in the UV-Vis Spectrum of 1.Cu on

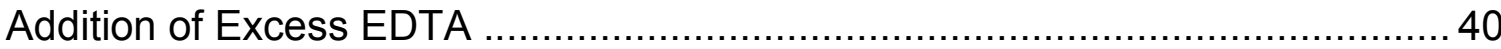

Figure 25. ESI-MS Analysis of $\mathrm{Cu}^{2+}$ Chelation From 1 $\cdot \mathrm{Cu}$ by EDTA ................ 41

Figure 26. ESI-MS Analysis Revealed that EDTA Chelates $\mathrm{Cu}^{2+}$ From 1·Cu

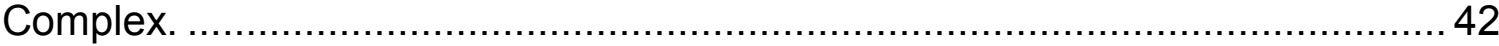

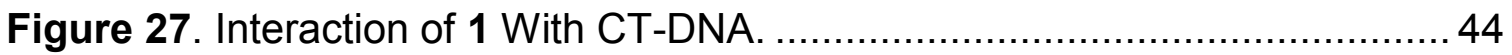

Figure 28. Gel Shift Analysis Showing Cleavage of pUC19 DNA In The Presence of 1 46

Figure 29. Gel Shift Analysis Showing Cleavage Of pUC19 DNA In The

Presence of 1.Cu. 46

Figure 30. Gel Shift Analysis Showing Cleavage Of pUC19 DNA. .................. 47

Figure 31. Proposed Mechanism For DNA Cleavage By 1·Cu. 48

Figure 32. A Natural Prodigiosin (Red 2) and Prodigisoin and Tambjamine Analogues (1-10) Used in the Study. 51

Figure 33. A Representative UV-Vis Absorbance Spectrum For Prodigiosin Analogue as a Function of $\mathrm{pH}$ and the First Derivative Plot of Change in

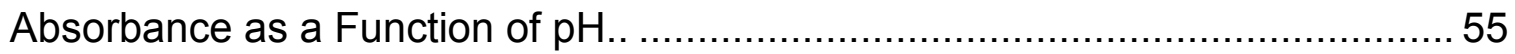

Figure 34. Mass Spectra Showing Formation of Red2 $\cdot \mathbf{C u}$ Complex............... 58 Figure 35. Mass Spectra Showing In Situ Formation of 1·Cu Complex and 1·Zn Complex In $90 \% \mathrm{MeOH}$. 59

Figure 36. ESI-MS Showing Formation of 2.Cu Complex in 90\% $\mathrm{MeOH}$.......... 60

Figure 37. ESI-MS Showing Formation of 3.Cu Complex in $90 \% \mathrm{MeOH}$..........61 61

Figure 38. ESI-MS Showing Formation of 4.Cu Complex in $90 \% \mathrm{MeOH}$.......... 62

Figure 39. ESI-MS Showing Formation of 5. Cu Complex in $90 \% \mathrm{MeOH}$.......... 62

Figure 40. Spectral Changes Observed in the Interaction of Red2 With Varying Concentrations of CT-DNA. 64

Figure 41. Spectral Changes Observed in the Interaction of 2 With Varying Concentrations of CT-DNA. 66

Figure 42. Interaction of 3 With CT-DNA. 67

Figure 43. Interaction of 4 With CT-DNA. 68 


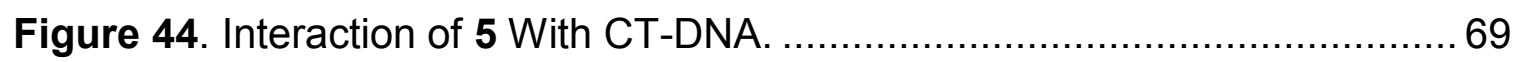

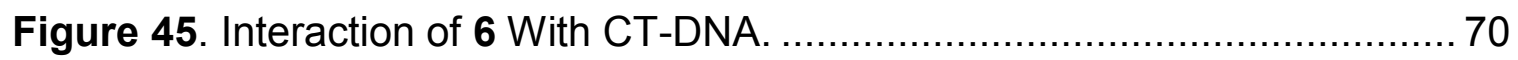

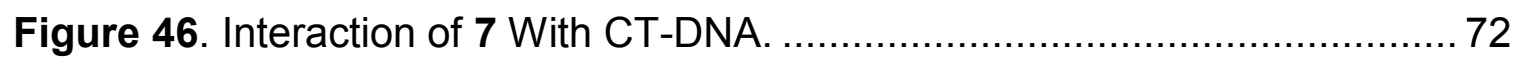

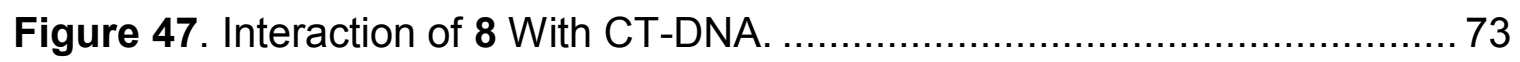

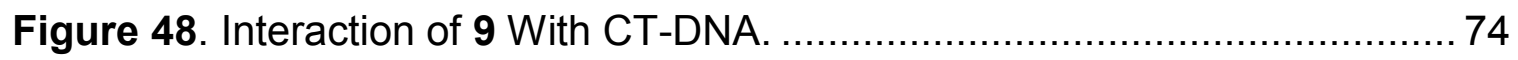

Figure 49. Gel Shift Analysis Showing Cleavage of pUC19 DNA in the Presence

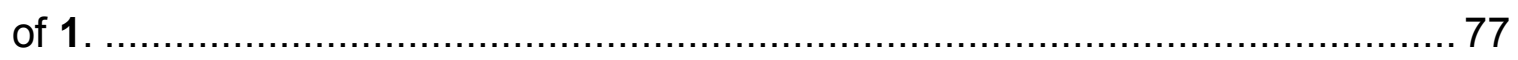

Figure 50. DNA Linearization With Increasing Concentration of Red2 ............ 78

Figure 51. DNA Linearization With Increasing Concentration of $4 \ldots \ldots \ldots \ldots \ldots \ldots \ldots . . .78$

Figure 52. DNA Linearization With Increasing Concentration of 7 .................. 79

Figure 53. DNA Linearization With Increasing Concentration of 10................ 79

Figure 54. Time Dependent Cleavage of Supercoiled pUC19 DNA With 6. ...... 82

Figure 55. Time Dependent Cleavage of Supercoiled pUC19 DNA With 10.... 82

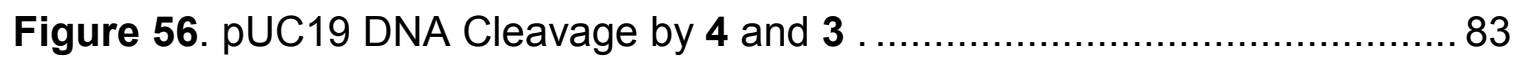

Figure 57. Time Dependent pUC19 DNA Cleavage With Corresponding Kaleidagraph Plot for Red2.

Figure 58. Time Dependent pUC19 DNA Cleavage With Corresponding

Kaleidagraph Plot for 8 . 86

Figure 59. Effect of Increasing lonic Strength on Rate of DNA Linearization by Red2. 87

Figure 60. Revised Model for the Cleavage of DNA by Prodigiosin and Tambjamine Analogues in the Presence of $\mathrm{Cu}^{2+}$ .90 


\section{List of Abbreviations/Symbols}

$\begin{array}{ll}\text { Pg } & \text { Prodigiosin } \\ \text { Tm } & \text { Tambjamine } \\ \text { DNA } & \text { Deoxyribonucleic Acid } \\ \text { SC DNA } & \text { Supercoiled Deoxyribonucleic Acid } \\ \text { ROS } & \text { Reactive Oxygen Species } \\ \text { dsDNA } & \text { Double Stranded Deoxyribonucleic Acid } \\ \text { SSDNA } & \text { Single Stranded Ribonucleic Acid } \\ \text { pDNA } & \text { Plasmid DNA } \\ \text { CT-DNA } & \text { Calf Thymus DNA } \\ \text { SOD } & \text { Superoxide Dismutase } \\ \text { CAT } & \text { Catalase } \\ \text { CQ } & \text { Chloroquine } \\ \text { EDTA } & \text { Ethylenediaminetetraacetic Acid } \\ \text { DMSO } & \text { Dimethyl Sulfoxide } \\ \text { ESI-MS } & \text { Electrospray lonisation Mass Spectrometry } \\ \text { TLC } & \text { Thin Layer Chromatography }\end{array}$




\subsection{Background}

Cancer is a major public health problem and there is great interest in the discovery and development of anticancer drugs as many current treatments, especially platinum based drugs, have toxicity problems ${ }^{1,2}$. As more research is carried out on the mechanisms of cancer tumorigenesis it has become clear that DNA is at the center of both the cause and treatment of cancer. DNA is the main driving force in tumorigenesis and also the main intracellular target in cancer chemotherapy ${ }^{3,4}$. The most common modes of action for most DNA-affecting antitumor agents are inhibition of DNA synthesis or DNA damage. Prodigiosins and tambjamines have been identified as new anticancer agents promoting apoptosis in a wide variety of human cancer cell lines such as gastrointestinal, breast and lung cancer cells, with no noticeable toxicity in nonmalignant cells ${ }^{5,6}$. This makes them candidate anticancer drugs. Ideally an anticancer drug should specifically target malignant cancer cells while having very little or no effect on non-malignant cells.

\subsection{Prodigiosins}

Bacteria produce a range of natural products that have been exploited for decades as pharmaceutically active compounds. One of these natural compounds, prodigiosin ${ }^{7}$, was first isolated and characterized in the 1930s and the structure elucidated in the $1960 \mathrm{~s}^{8}$. 
Prodigiosins are one of the best studied naturally occurring group of compounds isolated from bacteria including actinomycetes, Serratia spp., and Pseudomonas $\mathrm{spp}^{9}, 10$. These natural compounds are red-pigmented and the structure of prodigiosin is characterized by the three pyrrolic rings (ring A, B and C); existing in two interconverting forms: cis (or $\beta$ ) and trans (or $\alpha$ ) as shown in Figure 1.

(A)

(B)
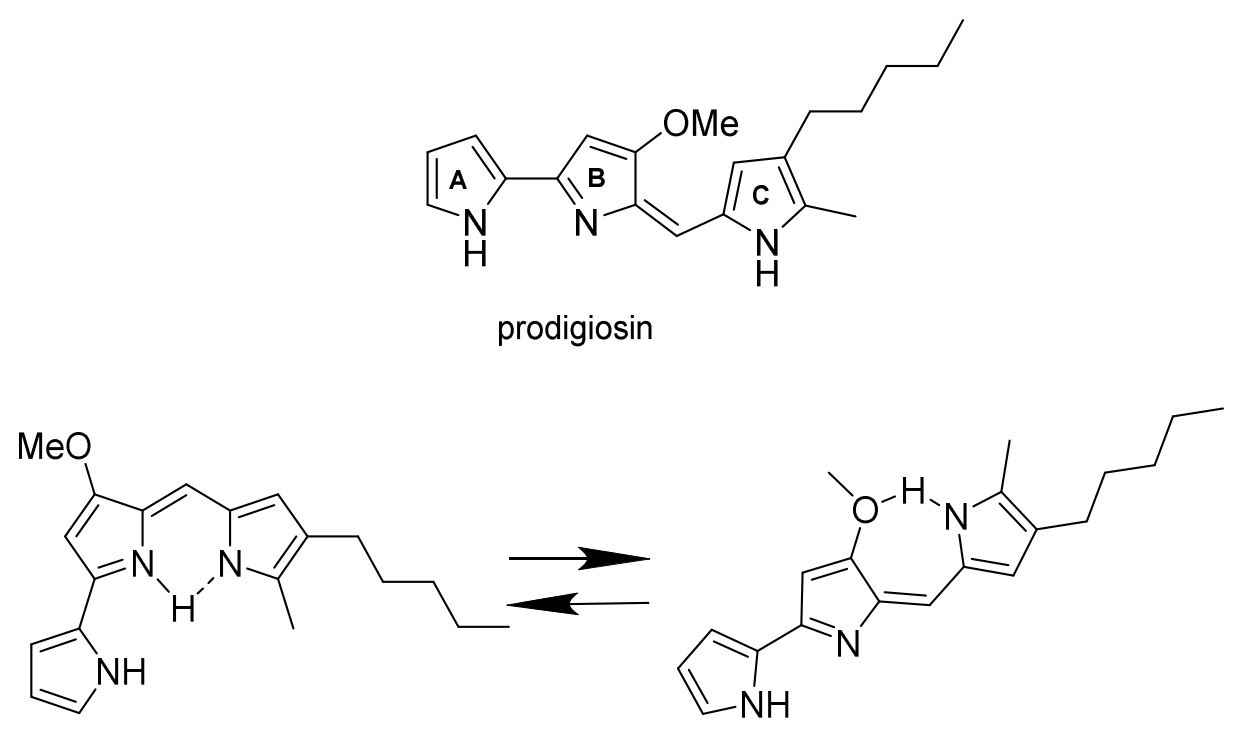

cis isomer

trans isomer

Figure 1. (A) Canonical structure of prodigiosin, (B) Isomeric forms of prodigiosin. The balance between the isomeric forms is $\mathrm{pH}$ dependent with the trans isomer being more easily protonated.

The representative members of the prodigiosin family shown in Figure 2 have the same pyrrolylpyrromethene skeleton with different alkyl substituents which may be linear but also often form rings or macrocycles.

Although the physiological functions of prodigiosin in the producing organisms are not known; the natural prodigiosins (Figure 2) have been shown to have a variety of biological activities which include antibacterial, antimalarial, antifungal, 
immunosuppressive, cytotoxic activities as well as involvement in surface adherence. Obatoclax, a prodigiosin analogue identified from a lead optimization of the compound streptorubin $B$ has made its way into phase 1 and phase 2 clinical trials for the treatment of different types of cancers ${ }^{11}$. In addition to these biological activities there is a plethora of possible applications for prodigiosin that can be developed upon particularly as the library of analogues grows with the combined utilization of synthetic chemistry and biotechnological methods (figure 3) ${ }^{9,12}$.

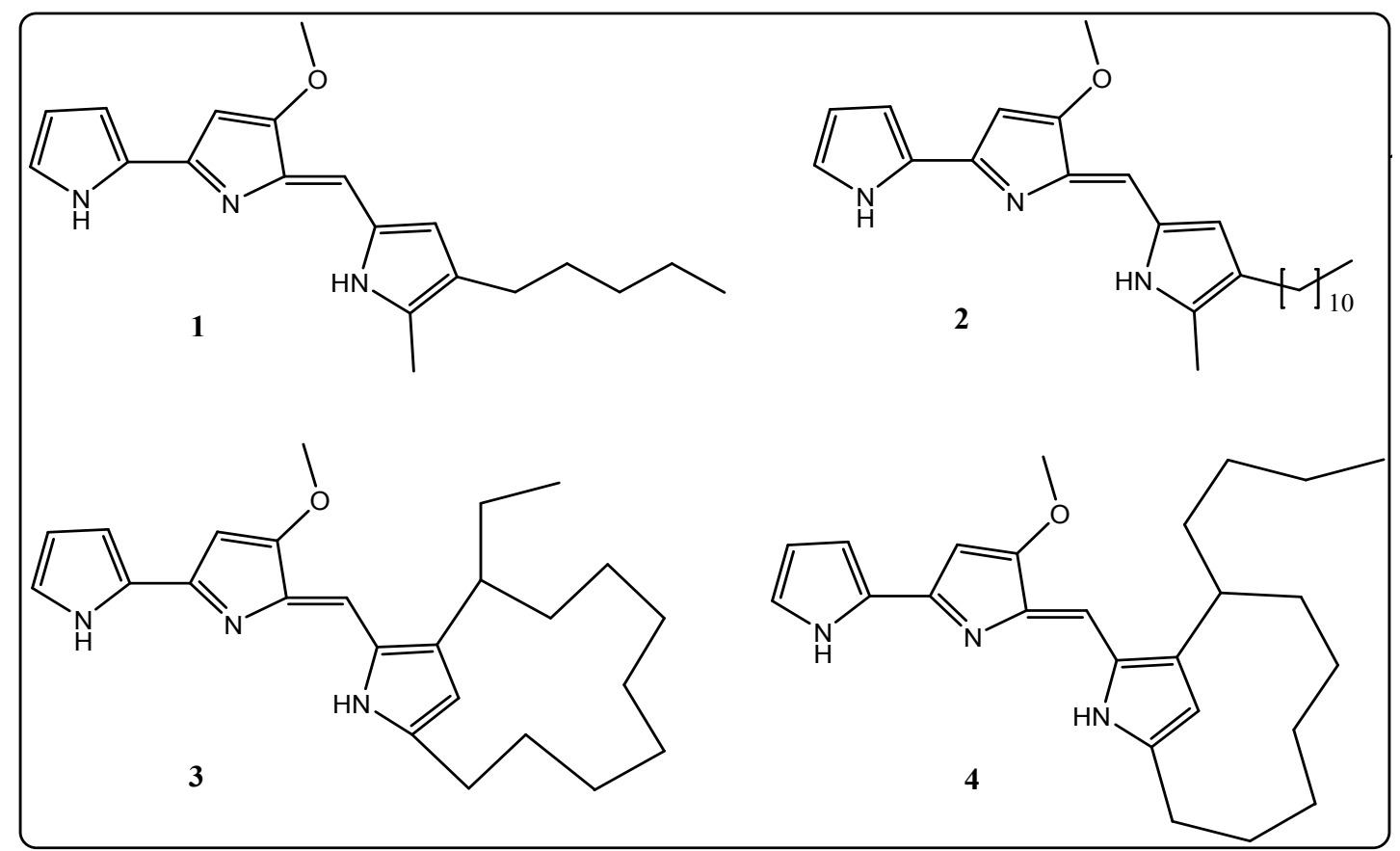

Figure 2. Some members of the natural prodigiosin family: 1. Prodigiosin, 2. Undecylprodigiosin, 3. Metacycloprodigiosin, 4. Streptorubin $\mathrm{B}^{13}$.

The prodigiosins have been shown to be able to induce apoptosis in rat hepatocellular and human breast cancer cell lines with very little effect on noncancerous cells ${ }^{9,10}$. The immunosuppressive properties of prodigiosins have been 
shown in their ability to inhibit the blastogenesis of $\mathrm{T}$ cells as well as their ability to selectively suppress the T cell-dependent antibody response without damaging the lymphoid organs ${ }^{14,15}$. The antimalarial activity of prodigiosins has also shown a lot of promise; metacycloprodigiosin isolated from the fermentation broth of Streptomyces spectabilis BCC 4785 was shown to have significant activity against P. falciparum and weaker cytotoxicity ${ }^{16}$.

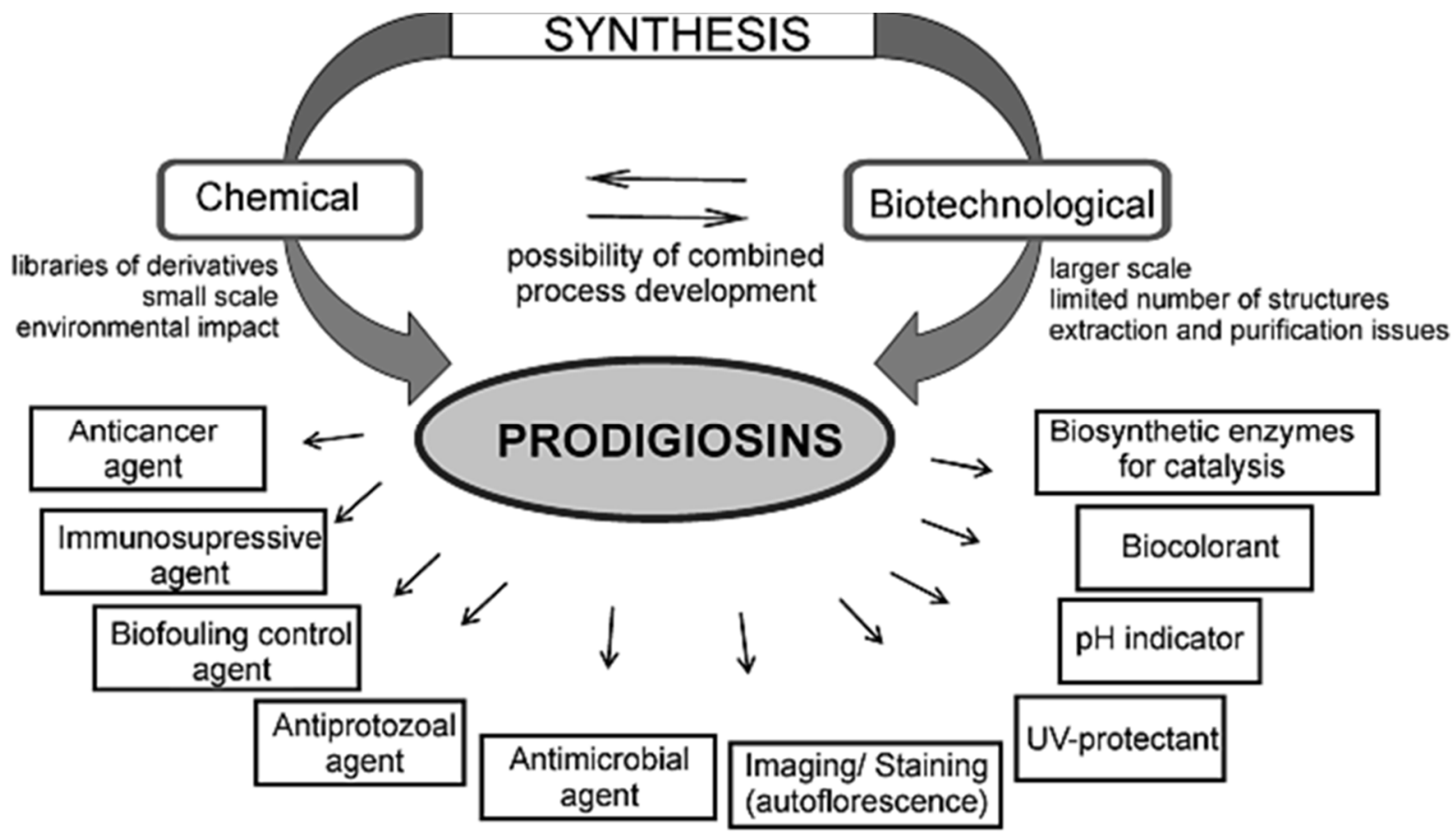

Figure 3. Synthesis and possible applications of prodigiosins; reproduced from reference ${ }^{9}$.

A recent study carried out to show direct comparison of the antimalarial activity of prodigiosin, undecylprodiginine, metacycloprodiginine and streptorubin B showed that these compounds had potent antimalarial activity with very low $\mathrm{IC}_{50}$ values (8, 
$7.7,1.7$, and $7.8 \mathrm{nM}$, respectively) against $P$. falciparum strain D6 and were slightly more active than $\mathrm{CQ}(11 \mathrm{nM})^{17}$.

There are multiple mechanisms of action that have been related to the biological activities of prodigiosins (figure 4). Some of these include disruption of intracellular $\mathrm{pH}$ gradients by $\mathrm{H}^{+} / \mathrm{Cl}^{-}$transport, inducing cell cycle arrest and facilitating oxidative DNA cleavage in the presence of $\mathrm{Cu}^{2+18,19,20}$. The ability of prodigiosins to damage DNA and change intracellular $\mathrm{pH}$ has led to their increased study in cancer research as these are some of the processes which can lead to the induction of apoptosis. In cells, prodigiosin has been detected in the nucleus, mitochondrial membrane, concentrated in the cytoplasm and also in granules located near the nucleus.

The presence of prodigiosin in the nucleus is interesting as it shows that prodigiosins are able to reach DNA if that is the cellular target on which they act in their mechanism of action. In addition, it has been found that the biosynthetic cluster of S. maracescens is always flanked by genes encoding a copper-efflux pump (cueR and copA). Although the function of this pump is not known, it is possible that it provides a way of reducing $\mathrm{Cu}^{2+}$ concentrations in the cell to reduce cleavage of its own DNA during prodigiosin production ${ }^{9,21}$. 


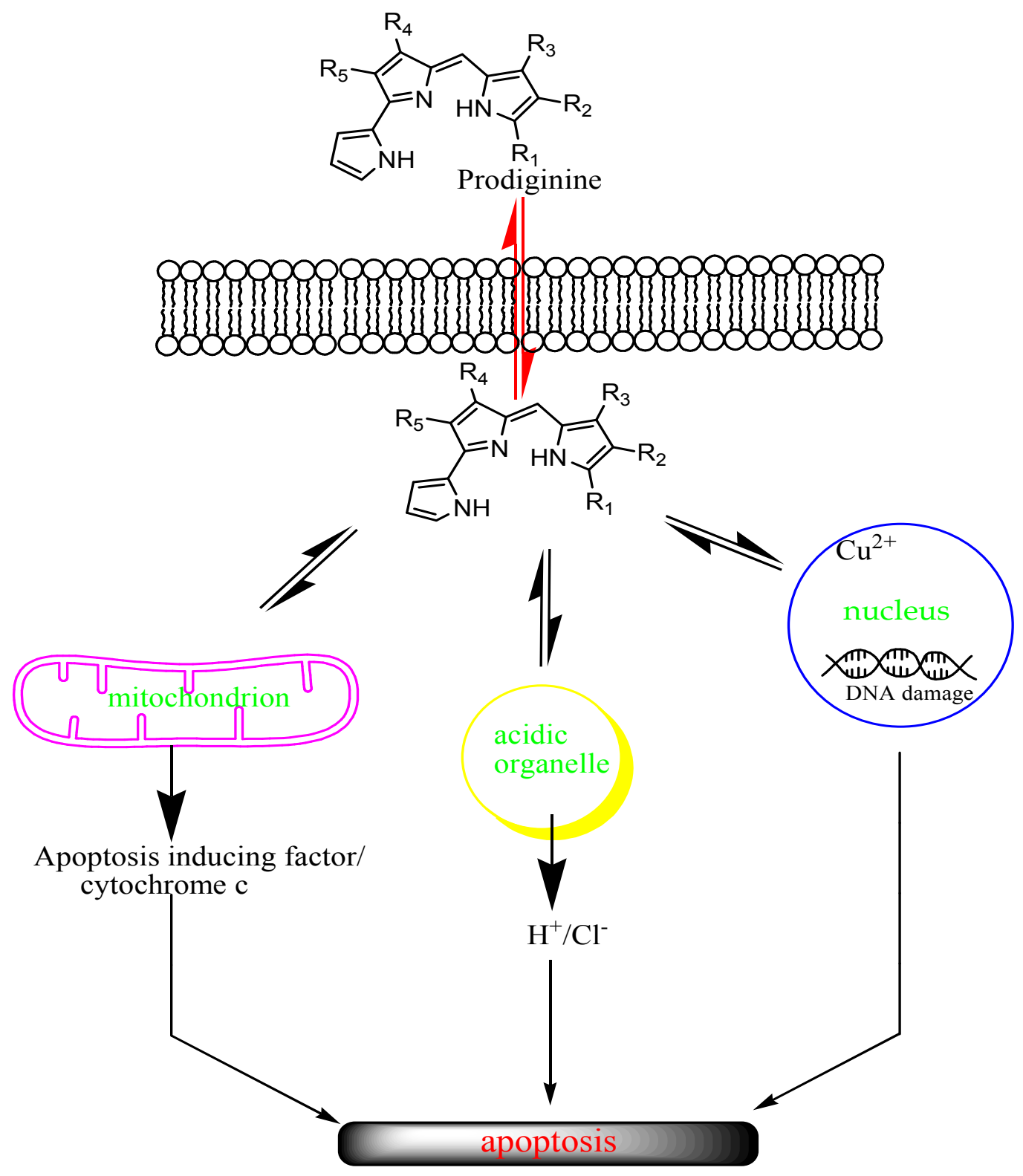

Figure 4. Some of the cellular processes affected by prodiginines; adapted from reference 22. 


\subsection{Tambjamines}

The tambjamines are also natural compounds isolated from bacteria and marine invertebrate animals. They are a group of alkaloids structurally closely related to prodigiosins and comprise two pyrrole rings with an enamine moiety at C-5 and a methoxy group at C-4. Most tambjamines have short alkyl chains substituted for the enamine nitrogen (figure 5).

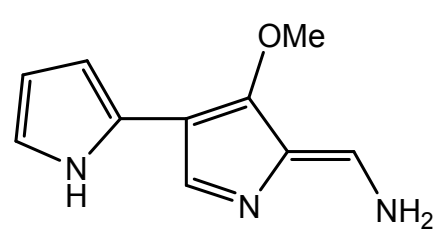

tambjamine A

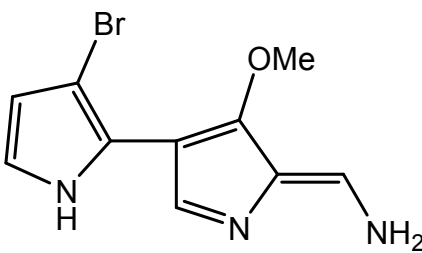

tambjamine B

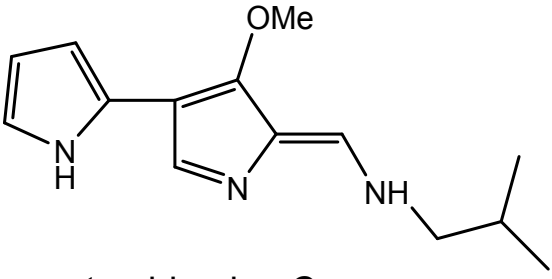

tambjamine C

Figure 5. Structures of tambjamines A-C.

The tambjamines have been implicated in chemical defense mechanisms of marine organisms against their predators. They possess a range of biological activities including antimicrobial, antitumour and immunosuppressive activities. The tambjamines have been shown to have antimicrobial activity against $E$. coli, Staphylococcus, B. subtilis, and Candida albicans ${ }^{22}$.

Prodigiosins and tambjamines have been previously shown to interact with DNA. For some of the tambjamines their intercalation into DNA as well as their oxidative cleavage of single strand DNA has correlated well with their antitumor properties ${ }^{20 \text {, }}$ $23,24,20,25$. Borah and co-workers have previously suggested that tambjamines 
could potentially be developed as DNA probes and DNA targeting anticancer agents based on their ability to cause copper mediated DNA cleavage ${ }^{23,25}$. The DNA binding and nuclease activity of both prodigiosin and tambjamine compounds might explain some of their biological activities.

There is increased interest and research in the medicinal use and application of metal complexes. The success of cisplatin has led to the search for other metal complexes with pharmacological activities. There are several platinum anticancer agents currently in use. In addition there are a variety of non-platinum containing pharmaceuticals in use as well. Metal complexes of prodigiosins and tambjamines will add to this growing library of metal complexes with pharmacological activities. This thesis reports my efforts to study the chemistry of prodigiosins and tambjamines, their metal binding ability as well as the effect of their metal complexes on their DNA binding modes and cleavage abilities. The prodigiosins and tambjamines possess pyrrolic nitrogens and are electron rich leading to various coordination abilities. The covalent attachment of prodigiosins and tambjamines to metals can yield complexes with novel DNA interactions that can influence biological activity. The metal complexes introduce new modes of binding to DNA not only through the change in geometry of the ligand when complexed with different metals, but also the ability of the complex to interact with DNA by both metal coordination and through intercalation of the attached ligand. The following chapters lay out the background and experimental approaches to this study followed by the specific aims of this Ph.D. thesis. 


\subsection{Introduction}

\subsection{The structure of DNA}

The double helical structure of DNA was deduced over six decades ago by Watson and Crick using X-ray diffraction patterns of DNA to deduce information about the double helix. DNA is contained in the cell nucleus of eukaryotes where it is packed into chromosomes. The DNA occurs as a double helical molecule. The two strands that form the DNA helix run in opposite directions and are complementary to each other because the sequence on one strand determines the sequence on the opposite strand (figure 6).

DNA contains two purine bases adenine $(A)$ and guanine $(G)$ and two pyrimidine bases cytosine (C) and thymine (T). In addition, DNA also contains a pentose, 2'deoxy-ribose which is covalently attached to a base to make a nucleoside. When a phosphate group is attached to the nucleoside, a nucleotide is formed. The nucleotides are joined together covalently through phosphate group bridges in which the 5' phosphate group of one nucleotide is joined to the 3'-OH group of the adjacent nucleotide forming a phosphodiester bond.

The purines in DNA are weakly basic aromatic molecules. The purines are nearly planar and the pyrimidines are planar molecules. The bases in DNA stack together through hydrophobic interactions. These base stacking interactions help to stabilize the 3-dimensional structure of DNA. Purines and pyrimidines also possess functional groups; ring nitrogens, carbonyl groups and amino groups that are involved in hydrogen bonding. The two strands of DNA are joined by hydrogen 
bonds formed between the bases. Two hydrogen bonds are formed between A-T pairs and 3 hydrogen bonds between G-C pairs.

DNA can adopt a variety of conformations depending on its environment and primary structure. Forms $A, B, C, D$ and $Z$ have been identified, with form $B$ being the most prominent (figure 7$)^{26}$.

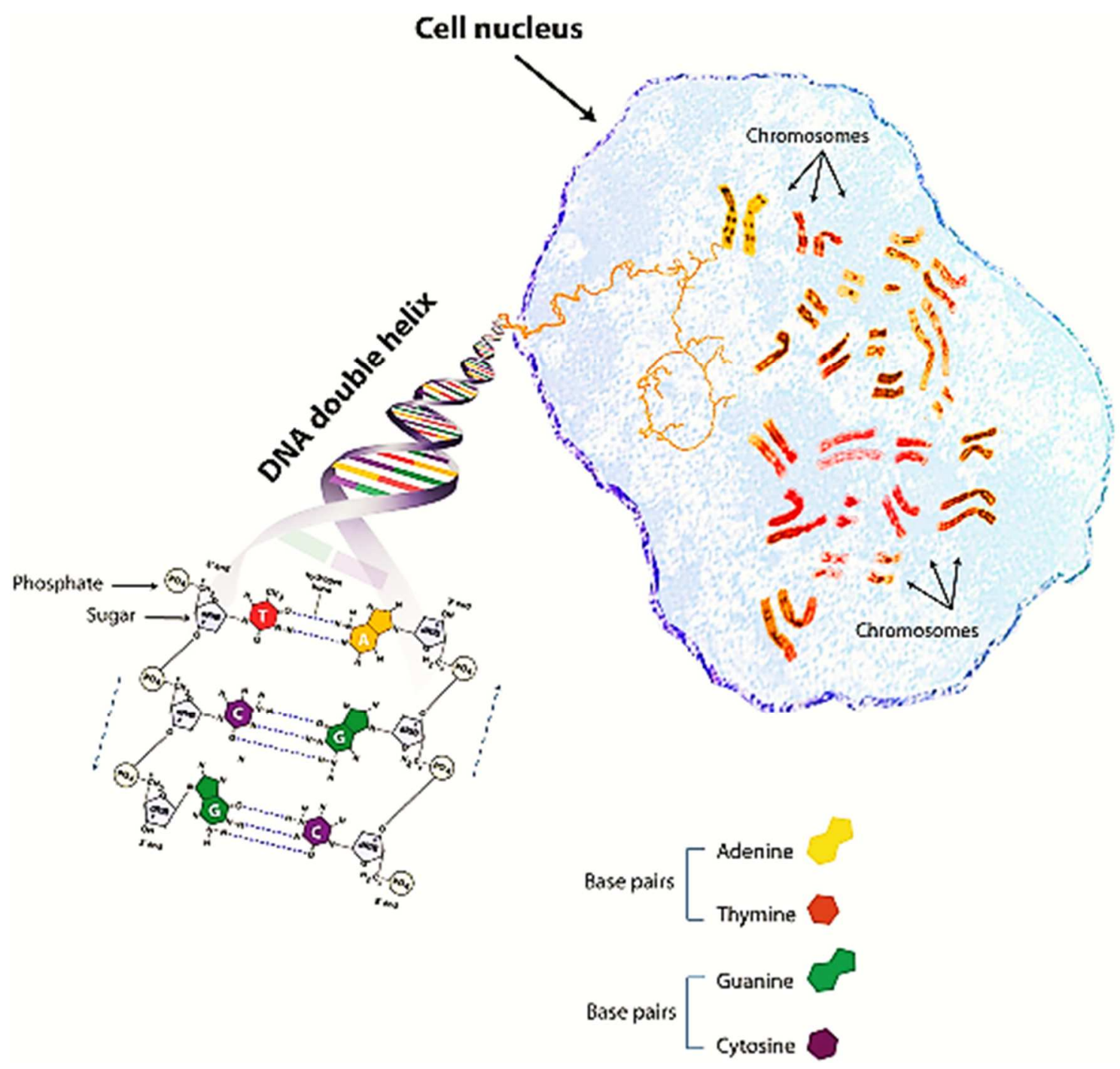

Figure 6. DNA occurs in the nucleus packed into chromosomes. The two strands of DNA form the double helix which is made up of two strands held together by hydrogen bonds between A-T and G-C base pairs ${ }^{27}$. 

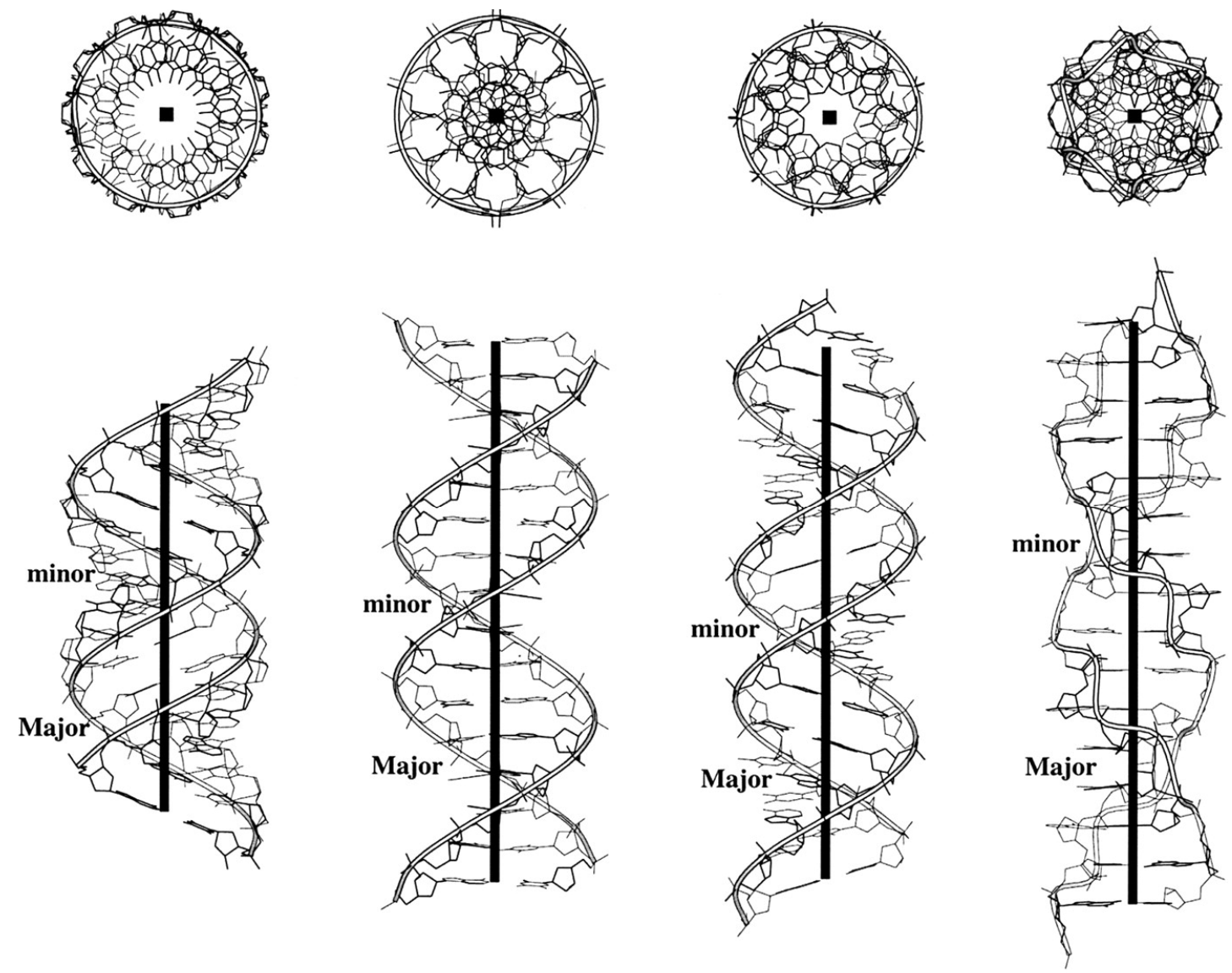

A-DNA

B-DNA

C-DNA

Z-DNA

Figure 7. Features of regular helical structures of $A, B, C$ and $Z$ DNA deduced from representative $X$-ray fiber diffraction models ${ }^{26}, 28$. In addition DNA can also occur in triplex (H-DNA), tetraplex (G- quadruplex DNA) and i-motif. These forms are possible due to unusual (Hoogsteen) base pairs ${ }^{29}$. 


\subsection{DNA Binding Modes}

There are 3 main modes of binding between DNA and small molecules:

1. Intercalation

This type of interaction can occur from either the major or minor groove and is stabilized by $\pi$ interactions of the complexing molecule and nucleobases of DNA. Intercalation involves the insertion of a planar molecule between DNA base pairs, which results in a decrease in the DNA helical twist, cause DNA backbone distortion and lengthening of the $\mathrm{DNA}^{30}$.Intercalation results in an increase in separation of nucleobases that leads to a distortion in the helix. To make up for this distortion the DNA duplex can partially unwind.

\section{Groove binding}

Small molecules and metal complexes can interact with DNA through either the major or minor groove. The size, shape, charge and hydrogen bonding potential determines which groove the complex will access as well as whether the complex will react with the backbone or nucleobases. Some ruthenium derivatives that have strong hydrogen bonding potential have been shown to favor major groove binding ${ }^{31}$.

3. Outside edge / electrostatic interactions.

These involve ligands (metal ions) to the outside of the helix through electrostatic interactions with the sugar phosphate backbone. The association of positively 
charged counter ions with the DNA polyanion has a large effect on DNA conformation and stability.

Metal complexes interact with DNA through intercalation, groove binding and electrostatic interactions (figure 8). Intercalation and groove binding are the two most important binding modes when it comes to DNA damage.

a.

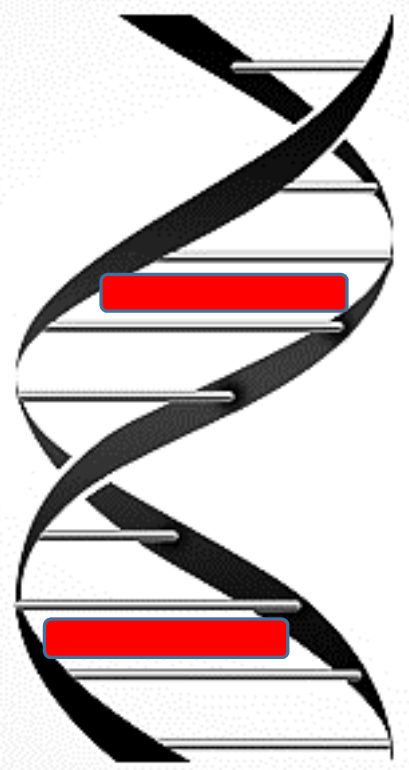

b.

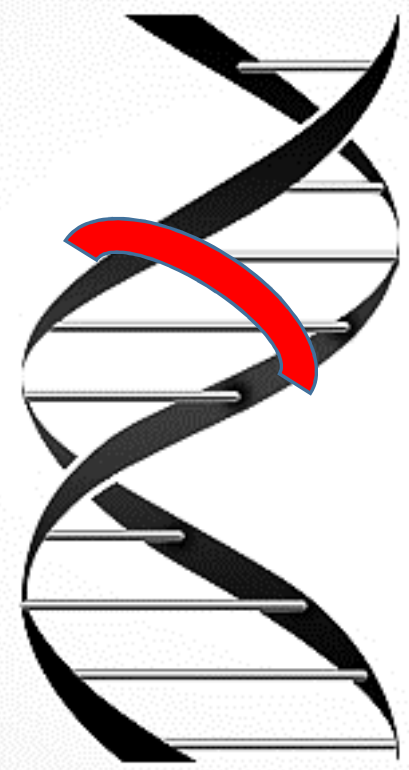

c.

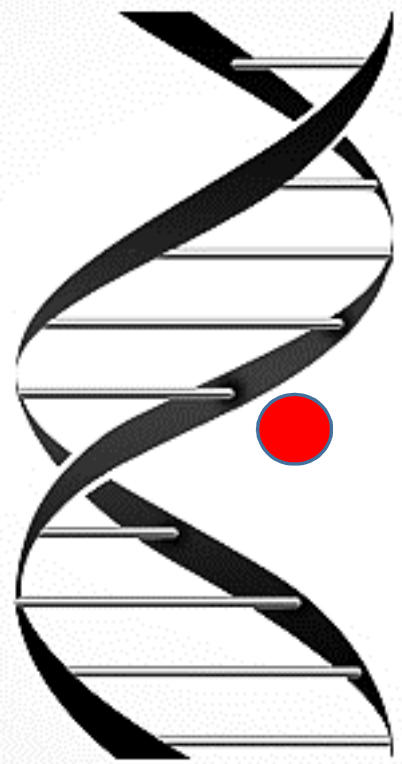

Figure 8. Binding modes of small molecules to DNA: a. intercalation, b. groove binding, c. outside edge/ electrostatic interactions.

Groove binding, does not induce the large conformational changes in DNA that happen with intercalation. Groove binders are usually crescent-shaped molecules that bind to the minor groove of DNA and block DNA protein interactions ${ }^{30,32}$. Both groove binding and intercalation can lead to anticancer and anti-bacterial properties of molecules, so drugs that bind DNA cannot be distinguished as groove binders or intercalators based solely on their pharmacological effects. The 
intercalating ability of metal complexes has been shown to increase with increased planarity of the compounds and coordinate geometry of the ligand while the donor atom influences both binding mode and extent of binding to DNA ${ }^{33,34}$. There are several methods that can be used to determine whether mode of binding is intercalation or groove binding. One of the most commonly used methods is UVvisible spectrophotometry. Molecules containing aromatic or phosphate chromophore groups can interact with the double helix structure of DNA, and this interaction can be observed as changes in the absorption spectra in the absence and presence of the small molecule. The changes are seen as red shift or blue shift as well as hyperchromic or hypochromic effects. Hypochromicity at $260 \mathrm{~nm}$, the maximum absorption of DNA, indicates the compaction of DNA due to the electrostatic interaction ${ }^{35}$. Intercalation lengthens the DNA helix as DNA base pairs undergo some separation in order to accommodate the small molecule inserting itself; this leads to hyperchromicity at $260 \mathrm{~nm}^{36}$.

Viscosity studies can also be used to determine mode of binding. This is because viscosity is sensitive to the length of DNA and so this makes this method very sensitive for intercalators ${ }^{36}$. Other modes of binding do not result in lengthening of DNA. Groove binders and non-classical or partial intercalators can cause kinks (bends) in DNA, and this reduces the length of DNA ${ }^{36}$.

Ligand binding to DNA can disrupt protein-DNA interactions and thus affect other important biological processes that occur as a result of successful protein-DNA interactions. We have a library of novel analogs of the natural prodigiosins and tambjamines which was synthesized in continuation of a drug discovery program 
aimed at finding an efficient antimalarial agent. Most of these analogs exhibited enhanced antimalarial activity against chloroquine-sensitive (CQS) D6 and chloroquine-resistant (CQR) Dd2 and 7G8 strains of $P$. falciparum as well as improved toxicological profiles in human liver hepatocellular carcinoma cell line $\left(\right.$ HepG2) ${ }^{12}$.

We are interested in the nature of complexes that these compounds form with $\mathrm{Cu}^{2+}$ and $\mathrm{Zn}^{2+}$ and their DNA binding activities, because there has been a lot of interest in transition metal complexes of small molecules as drug candidates or diagnostic agents.

\subsection{Supercoiled DNA and Small Molecule Interactions}

Supercoiled DNA can be used as a drug substrate for the detection of drug DNA interactions. Supercoiled DNA is also called SC or form I DNA, and DNA binding compounds can bind to this form of DNA and convert the SC DNA into an open circular (OC or form II) DNA. Many compounds that interact with and damage DNA show common features in their structure and effects; intercalators are usually planar and can lead to DNA strand breaks, while groove binders are crescent shaped and do not usually lead to lots of side effects (figure 9$)^{30}$. 
Typical intercalators

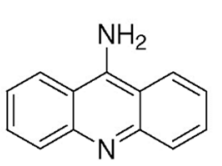

9-Aminoacridine

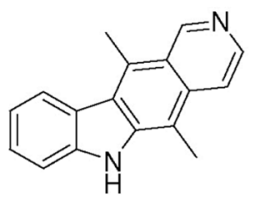

Ellipticine
Atypical intercalators

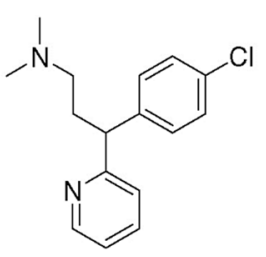

Chlorpheniramine

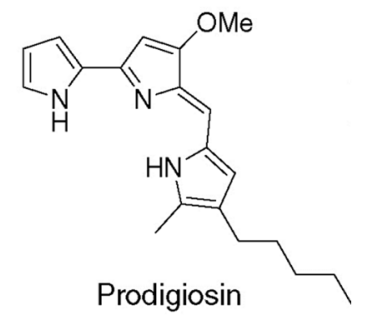

\section{Groove binders}

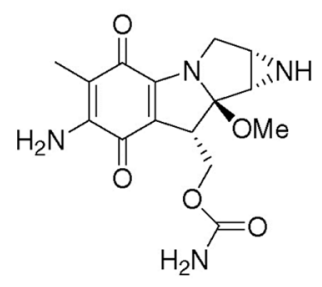

Mitomycin

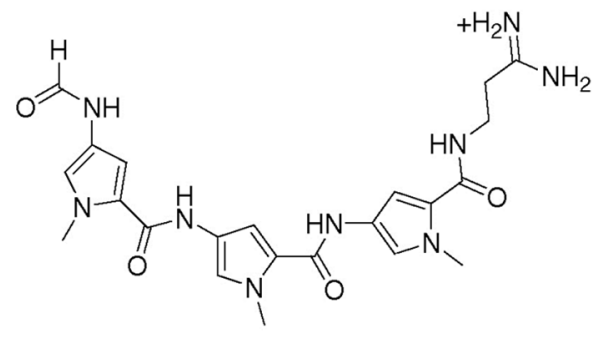

Distamycin

Figure 9. Structures of some intercalators and groove binders from reference ${ }^{37}$.

Some of the earliest examples of metals and their compounds being used in medical applications date from as far back as 3000 BC, when the ancient Egyptians were using copper sulfate to sterilize the water used in their tonics and the Romans using zinc to promote wound healing. However, the use of metalbased drugs was stopped largely due to their systemic toxicity and also development of newer drugs ${ }^{38}$.

Over the last three decades, however, there has been renewed interest in the metal complexes as pharmaceuticals. Some of these are shown in Fig 10. Some of these metal containing compounds can act as nucleases and chemically modify SC DNA to OC DNA and further into a linear (LC or form III) DNA conformation. DNA is very stable to covalent bond cleavage and requires use of enzyme 
nucleases for strand scission of the phosphodiester backbone to occur. The halflife of DNA under physiological conditions has not been measured but had been extrapolated to $10^{6}$ years ${ }^{39}$. As a result of this high hydrolytic stability, metal nucleases would need to promote strand scission by a high magnitude in order to facilitate the reaction ${ }^{40}$. Cisplatin, a clinical antitumor drug, has been shown to convert SC DNA to form II by promoting the alkylation of guanine bases ${ }^{41}$.<smiles>N[PH](N)(Cl)Cl</smiles>

$$
\text { cisplatin }
$$<smiles></smiles>

$[\mathrm{Cu}(\mathrm{ph})(\mathrm{phen})] \cdot 2 \mathrm{H}_{2} \mathrm{O}$<smiles>N[PH]1(NC2CCCCC2)OC(=O)C(=O)O1</smiles>

oxaliplatin<smiles></smiles>

[Cu(ph)(2,2'-bipy)].2 $\mathrm{H}_{2} \mathrm{O}$

Figure 10. Some metal complexes that have clinical uses ${ }^{42,43}$.

Activated bleomycin $\left(\mathrm{Fe}^{2+} \mathrm{BLM}\right.$ or $\left.\mathrm{Cu}^{2+} \mathrm{BLM}\right)$ has been shown to interact with DNA very strongly and causes scission of the DNA through formation of reactive oxygen species $(\mathrm{ROS})^{44}$. 


\subsection{DNA damage}

Damage to DNA can occur through different mechanisms, namely:

1. Hydrolysis of phosphodiester bond

2. Oxidation of nucleobases

3. H- abstraction from ribose

\subsubsection{Hydrolytic DNA Cleavage}

The hydrolytic cleavage of DNA occurs in the presence of metal ions which act as Lewis acids. The Lewis acids can either activate the phosphate group, making it susceptible to nucleophilic attack, or alternatively the Lewis acid will activate $\mathrm{H}_{2} \mathrm{O}$ or $\mathrm{OH}^{-}$as nucleophile. The hydrolysis reaction occurs by a nucleophilic attack at the phosphate backbone to form a five-coordinate phosphate intermediate (figure 11). This is followed by cleavage of either the $3^{\prime}$ phosphate (common in enzymatic systems) or the 5'-phosphate, single strand scission and yielding R-OH and R-O$\mathrm{PO}_{3} \mathrm{H}_{2}$.
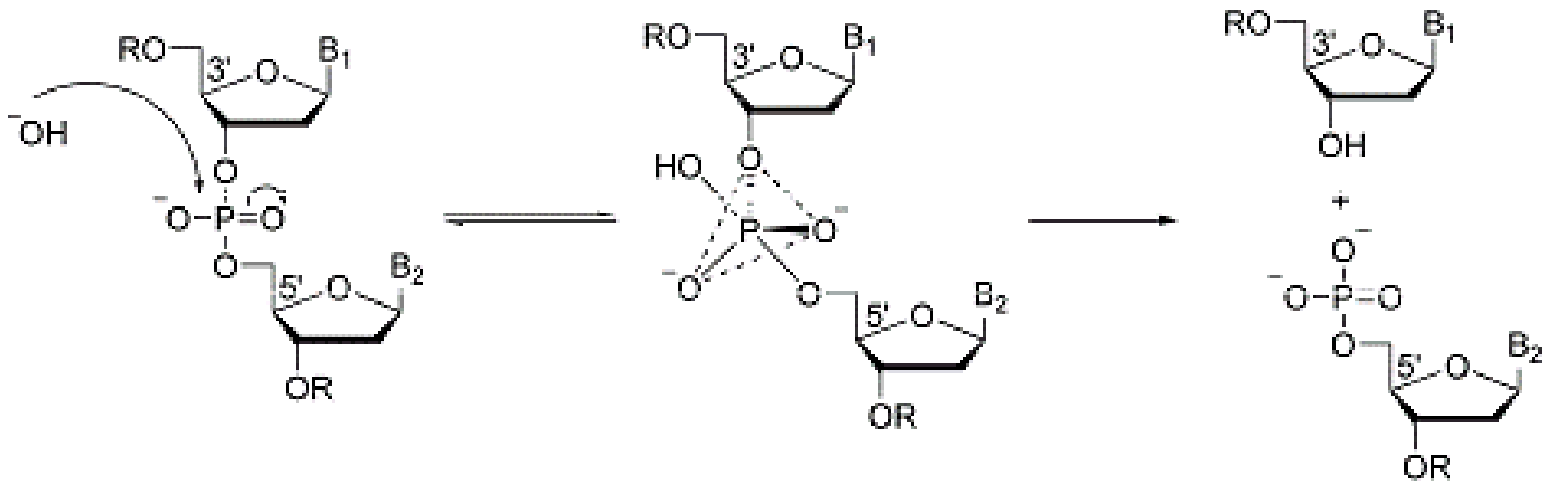

Figure 11. Proposed mechanism for the hydrolytic cleavage of DNA. 


\subsubsection{Oxidative DNA cleavage}

Normal cellular metabolism is the major source of ROS (figure 12) The electron transport chain has the potential to leak electrons to oxygen resulting in superoxide generation ${ }^{45}$. Cells are constantly exposed to ROS which are a result of processes occurring within the cells. Oxygen is vital in many biological processes but it can also lead to generation of ROS.

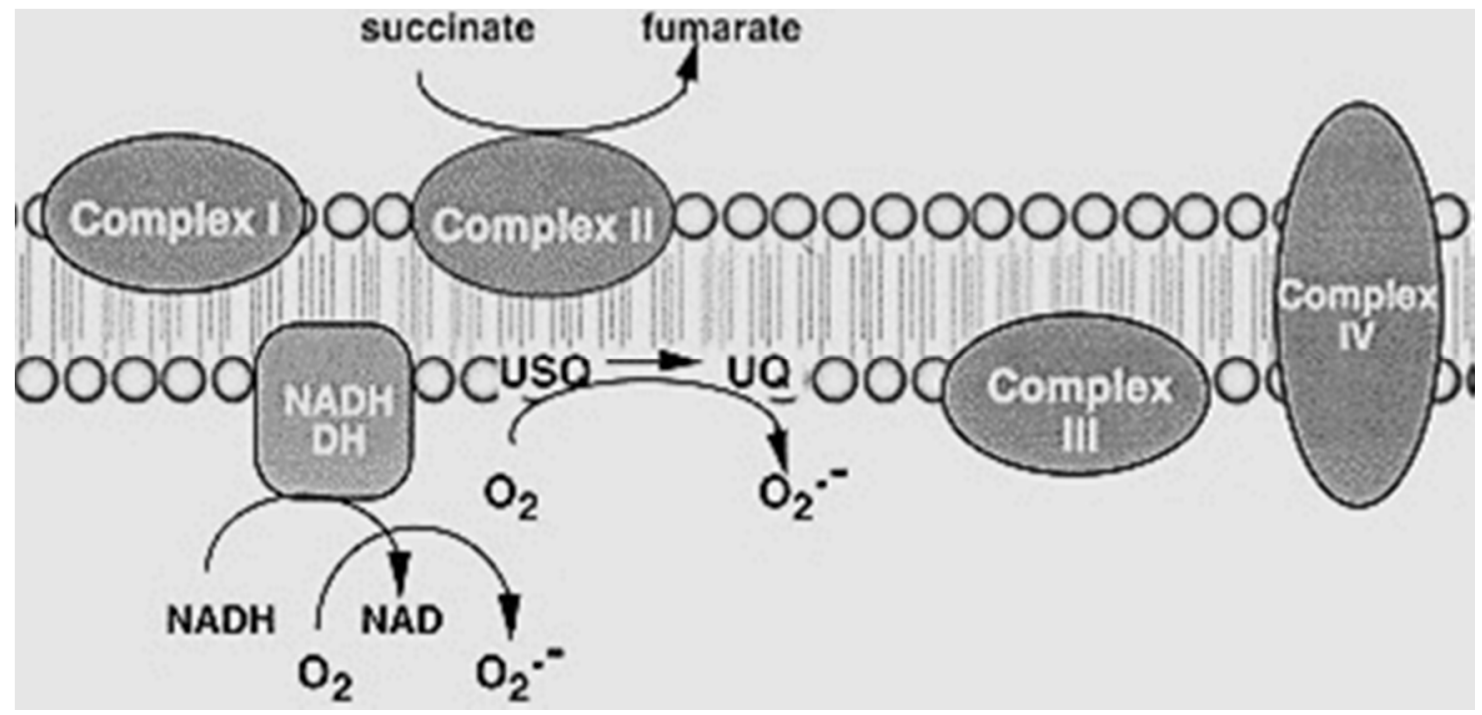

Figure 12. Reactive oxygen species production in the mitochondria ${ }^{46}$.

If the ROS are not removed, e.g. when antioxidants are depleted or the defenses cannot cope, the ROS will very often react with DNA, proteins and other components leading to undesirable effects i.e. single strand breaks, double strand breaks and chromosomal aberrations (Figure 13).

Oxidative DNA cleavage is facilitated by reactive intermediates which are usually reduced oxygen species. The oxygen species are produced from redox reactions 
with metal complexes and they react with the sugar moiety or with nucleobases leading to direct strand cleavage of labile strands in DNA.

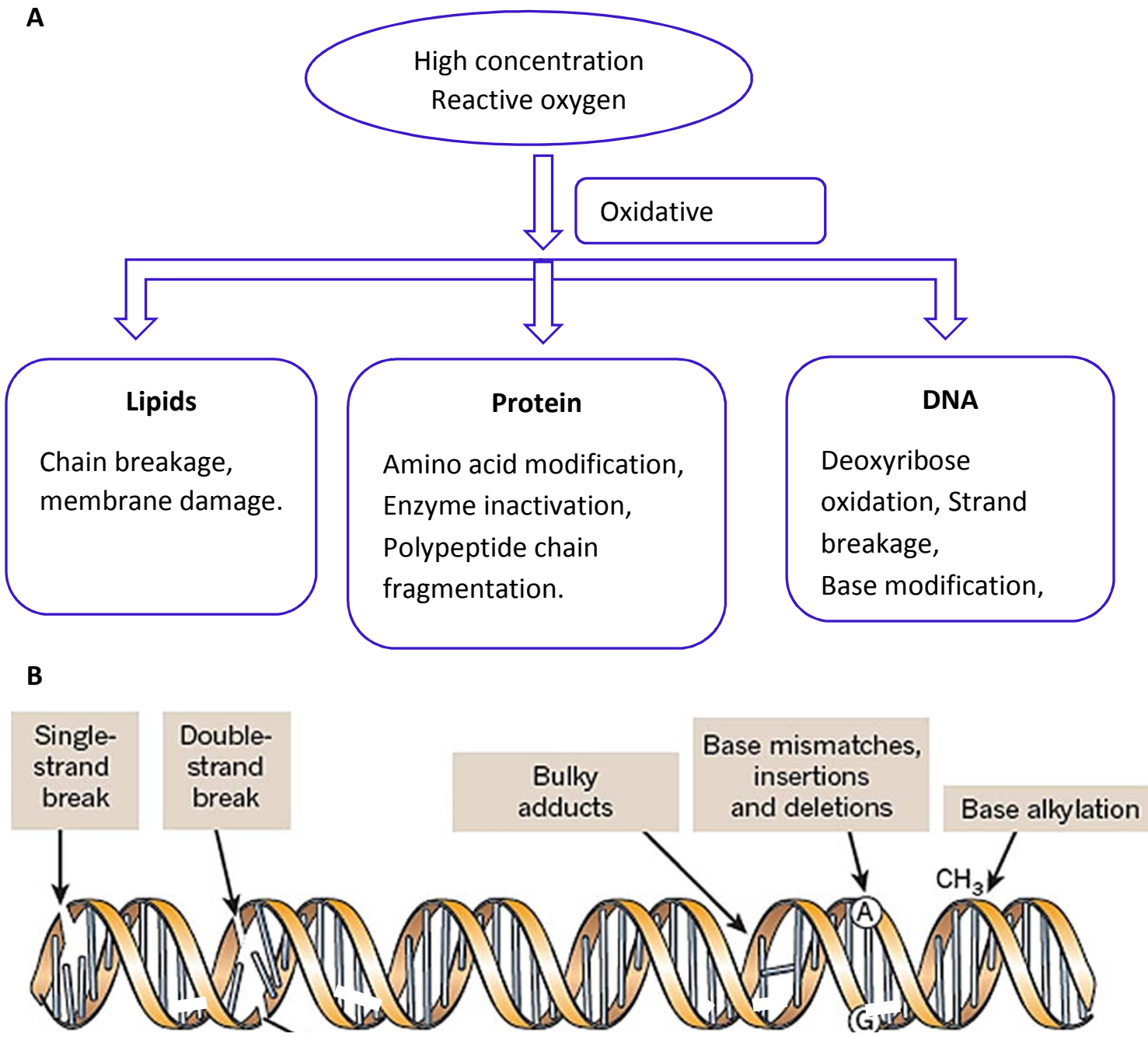

Figure 13. (A) Reactive oxygen species at high concentrations place cells in a state of 'oxidative stress' and this causes damage to lipids, proteins and DNA ${ }^{47}$. different types of DNA damage ${ }^{48}$. (B) Compounds that promote double strand DNA cleavage are cytotoxic because dsDNA damage is more difficult to repair than ssDNA damage. 
Of the ROS, the highly reactive free radicals react with compounds by addition and abstraction, depending on the electron density at the site of addition or abstraction. The hydroxyl radical $(\bullet \mathrm{OH})$ is highly reactive and reacts by adding to the double bonds of heterocyclic DNA bases (figure 14) and by abstracting an $\mathrm{H}$ atom from the methyl $\left(-\mathrm{CH}_{3}\right)$ group of thymine or $\mathrm{C}-\mathrm{H}$ bonds of deoxyribose ${ }^{47 \cdot 48}$

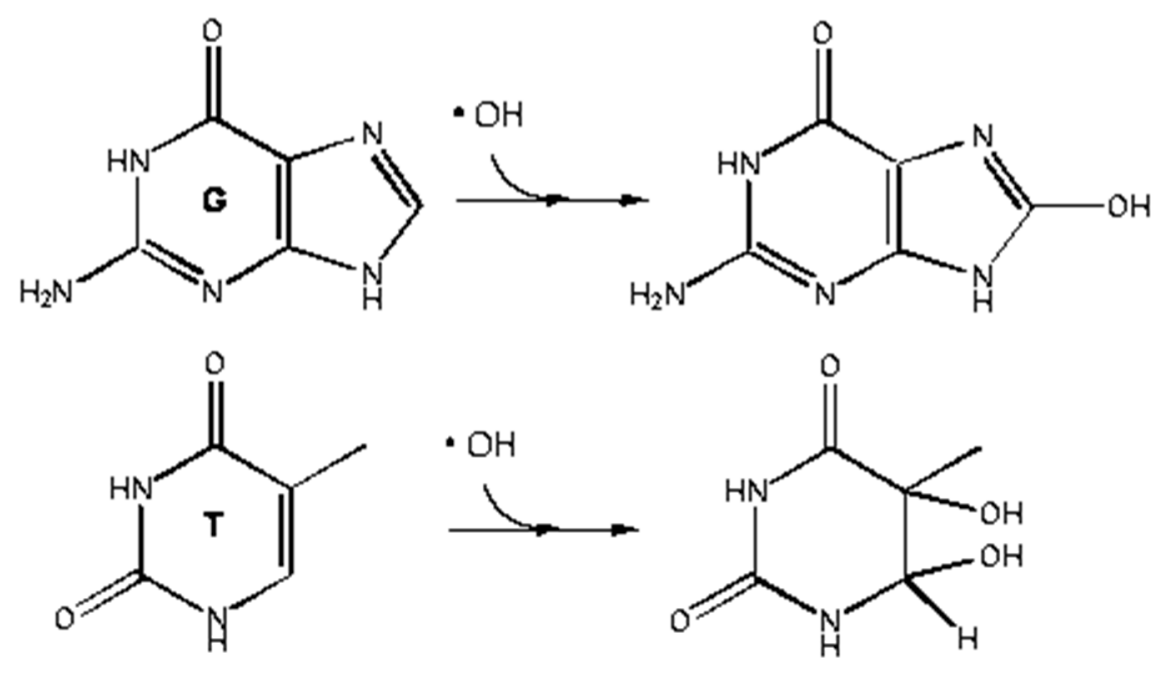

Figure 14. The hydroxyl radical reacts with DNA bases (guanine and thymine) by adding to the double bond.

Other types of products (figure 15) can be formed depending on whether oxygen is present or absent as well as other conditions. These products include DNA base damage products such as those from C-8 hydroxylation of guanine to form 8-oxo7,8-dehydro-2'-deoxyguanosine, hydroxymethyl urea, urea and thymine glycol ${ }^{47}$. One of the effects of oxidative DNA damage is mutation of DNA, which can lead to carcinogenesis as well as alterations in transcription ${ }^{46}$. 
<smiles>Nc1nc2[nH]c(O)nc2c(=O)[nH]1</smiles>

8-hydroxyguanine<smiles>O=c1[nH]c(O)c(O)c(=O)[nH]1</smiles>

5,6-dihydroxyuracil<smiles>Nc1ncnc2[nH]c(O)nc12</smiles>

8-hydroxyadenine<smiles>O=c1[nH]c(O)c(O)c(=O)[nH]1</smiles>

5-hydroxyuracil<smiles>Nc1nc(O)nc2[nH]cnc12</smiles>

2-hydroxyadenine<smiles>Nc1nc(=O)[nH]cc1O</smiles>

5-hydroxycytosine

Figure 15. Some DNA base damage products resulting from reactive oxygen species.

\subsection{Key Role of $\mathrm{H}_{2} \mathrm{O}_{2}$ in cells}

Hydrogen peroxide in the cells is produced mainly in mitochondria under conditions of metabolic stress from partial reduction of $\mathrm{O}_{2}$ leading to superoxide anion formation. Enzymes such as superoxide dismutase (SOD) catalyse the dismutation of superoxide radical to $\mathrm{H}_{2} \mathrm{O}_{2}$. Other enzymes such as monoamine oxidase and amino acid oxidase also lead to cellular $\mathrm{H}_{2} \mathrm{O}_{2}$ production ${ }^{49}$. In the cells concentration of $\mathrm{H}_{2} \mathrm{O}_{2}$ is determined by rate of formation of $\mathrm{H}_{2} \mathrm{O}$ by detoxifying enzymes catalase (CAT) and glutathione peroxide $(\mathrm{GPx})^{50}$.

In eukaryotes, $\mathrm{H}_{2} \mathrm{O}_{2}$ has been seen to have important roles as a signaling molecule in the regulation of a variety of biological processes. Cancer cells have been shown to have high cellular levels of this ROS and also produce high amounts of $\mathrm{H}_{2} \mathrm{O}_{2}{ }^{51,52}$. The anticancer effect of various chemotherapeutic agents currently in use such as 
paclitaxel and cisplatin can therefore be mediated, at least in part, by an increase in the cellular levels of $\mathrm{H}_{2} \mathrm{O}_{2}{ }^{53}$.

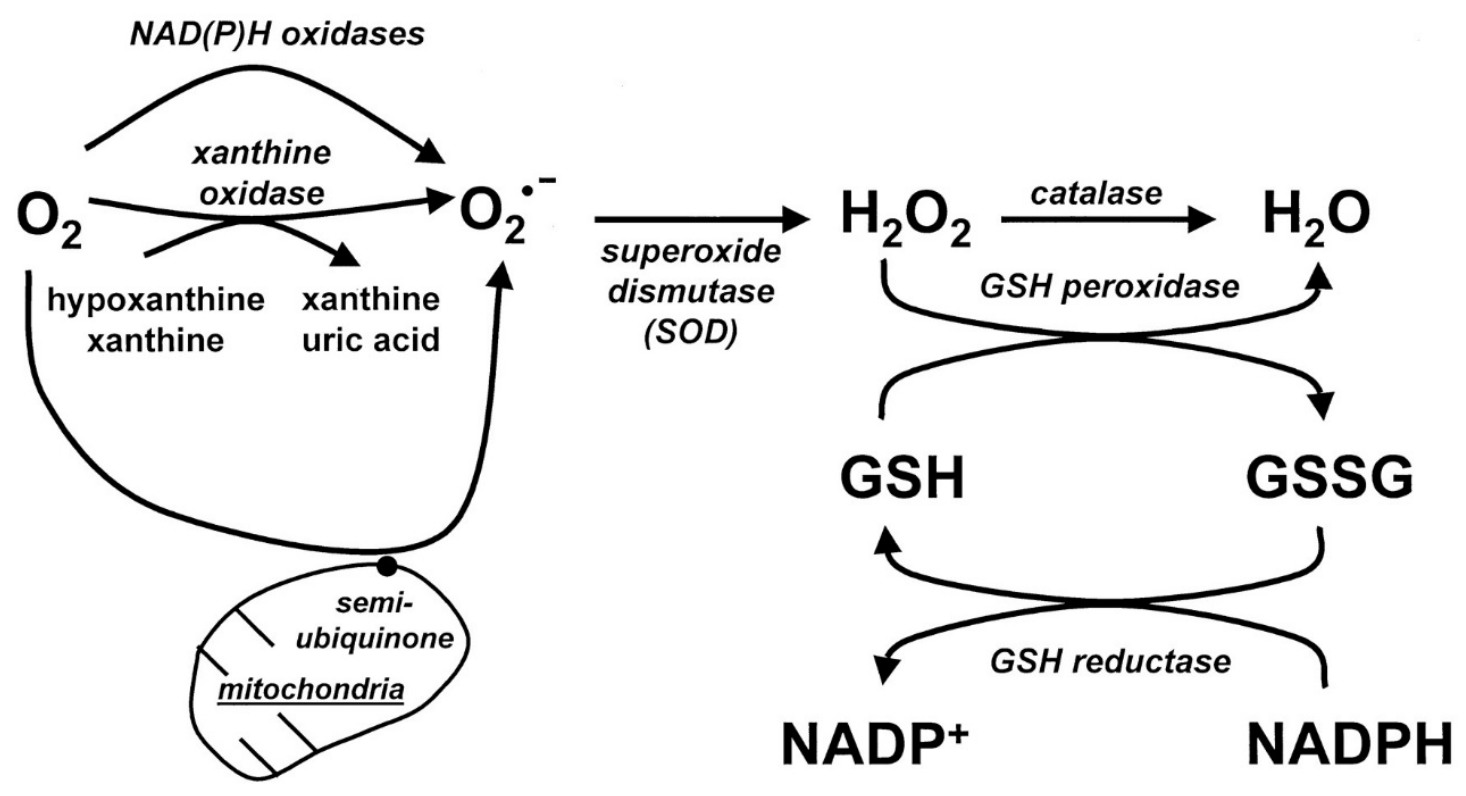

Figure 16. Pathways for generation of ROS production and detoxification ${ }^{54}$.

\subsection{Copper and Zinc in Biological Systems}

Copper and zinc are bioessential elements responsible for the function of many cellular enzymes and proteins. Both copper and zinc are found in various tissues and cellular compartments, and serum concentrations of both $\mathrm{Cu}^{2+}$ and $\mathrm{Zn}^{2+}$ have been reported to be between $15-20 \mu \mathrm{M}^{55}$.

Copper was first used by humans over 10,000 years ago. It belongs to group II metals of the periodic table with electronic configuration $[\mathrm{Ar}] 3 \mathrm{~d}^{10} 4 \mathrm{~s}^{1}$. In biological systems, copper ions usually exist in two oxidation states; the cuprous $\left(\mathrm{Cu}^{+}\right.$, reduced state) with electronic configuration $[\mathrm{Ar}] 3 \mathrm{~d}^{10}$ and cupric $\left(\mathrm{Cu}^{2+}\right.$, oxidized 
state) with electronic configuration $[\mathrm{Ar}] 3 d^{9}$. This redox nature of $\mathrm{Cu}$ allows for them to participate in electron transfer reactions ${ }^{56}$. Copper is essential for the activities of several proteins such as $\mathrm{Cu}-\mathrm{Zn}$ superoxide dismutase (Cu-Zn SOD), cytochrome oxidase as well as transcription factors ${ }^{57,58}$. High concentrations of $\mathrm{Cu}$ are toxic for both prokaryotic and eukaryotic cells ${ }^{59}$. The cupric ion $\left(\mathrm{Cu}^{2+}\right)$ can be reduced to cuprous $\left(\mathrm{Cu}^{+}\right)$by reductants, e.g. ascorbic acid. The $\mathrm{Cu}^{+}$formed is then able to facilitate formation of hydroxyl radicals $(\cdot \mathrm{OH})$ through the Fenton reaction by decomposition of $\mathrm{H}_{2} \mathrm{O}_{2}$. The redox reactions in which $\mathrm{Cu}$ participates can lead to formation of reactive oxygen species (ROS) which can potentially lead to damage to proteins, lipids and DNA. Attempts to establish how $\mathrm{Cu}$ complexes cause DNA damage or cleavage have mostly pointed to the likelihood of the involvement of hydroxyl radicals. This would happen through a Fenton-like process $^{59,60:}$

$$
\begin{aligned}
& \qquad \begin{aligned}
& \mathrm{LCu}(\mathrm{II})+\mathrm{H}_{2} \mathrm{O}_{2} \rightarrow \mathrm{LCu}(\mathrm{I})+\cdot \mathrm{OOH}+\mathrm{H}+ \\
& \mathrm{LCu}(\mathrm{I})+\mathrm{H}_{2} \mathrm{O}_{2} \rightarrow \mathrm{LCu}(\mathrm{II})+\mathrm{OH}^{-}+\cdot \mathrm{OH}
\end{aligned} \\
& \text { L= organic ligand }
\end{aligned}
$$$$
\text { Scheme } 1
$$

This suggestion was due to observed enhanced plasmid DNA cleavage in the presence of hydrogen peroxide $\left(\mathrm{H}_{2} \mathrm{O}_{2}\right)$. The $\mathrm{H}_{2} \mathrm{O}_{2}$ forms the hydroxyl $(\cdot \mathrm{OH})$ radical which either oxidizes the bases of DNA or generates other radicals leading to DNA strand scission at the phosphodiester bonds. If the oxidative cleavage occurs at 
the carbohydrate, abstraction of one hydrogen of deoxyribose (e.g C-3' abstraction) can initiate the oxidative cleavage process (figure 17).

Zinc occurs in the body as $\mathrm{Zn}^{2+}$, electronic configuration $[\mathrm{Ar}] 3 \mathrm{~d}^{10} . \mathrm{Zn}^{2+}$ is the single stable oxidation state in solution and so it does not play a redox active role in biological processes but it is important for the functioning of numerous proteins, enzymes (e.g. RNA polymerases, alcohol dehydrogenase, carbonic anhydrase, and alkaline phosphatase) and transcription factors where it plays catalytic, structural or regulatory roles.

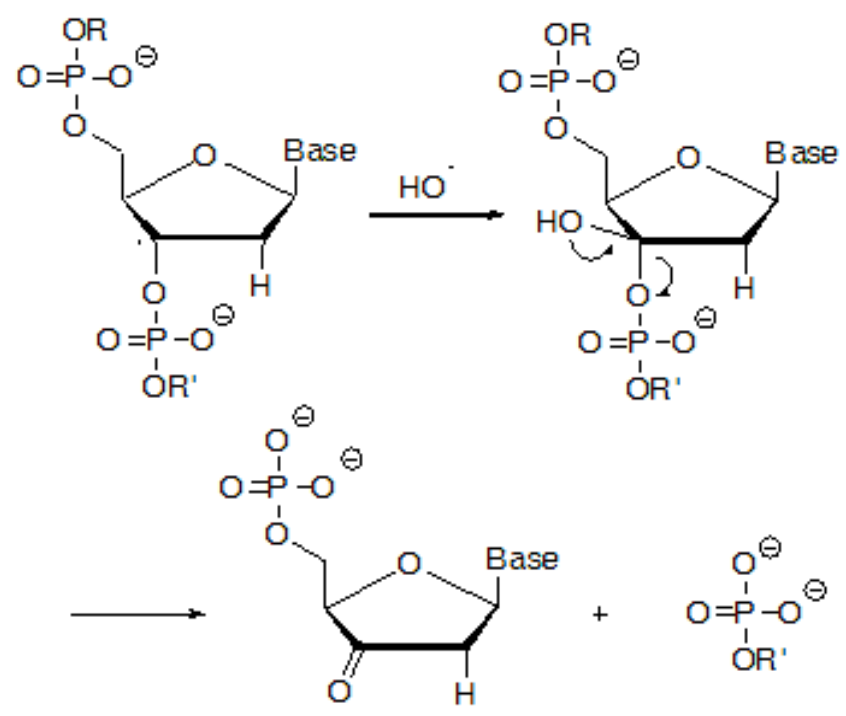

Figure 17. Oxidative cleavage by C-3' abstraction of deoxyribose

Although $\mathrm{Zn}^{2+}$ does not participate in one-electron redox reactions under biological conditions, it has been suggested that it may cause DNA damage through a hydrolytic mechanism ${ }^{61}$. Studies with $\mathrm{Zn}^{2+}$ complexes of quercetin and polyamine macrocyclic ligands have shown that exposure of SC DNA to $\mathrm{Zn}^{2+}$ complexes 
resulted in the disappearance of the SC DNA (Form I) accompanied by appearance of open-circular (Form II) ${ }^{61,62}$. Linearization of SC DNA by $\mathrm{Zn}^{2+}$ complexes has been observed only in experiments carried out over relatively long incubations (6-24 hours) at $37^{\circ} \mathrm{C}^{61,63}$.

\subsection{Specific Aims of This Proposal}

1. Syntheses and structure elucidation of $\mathrm{Cu}^{2+}$ and $\mathrm{Zn}^{2+}$ complexes of prodigiosin and tambjamine analogs.

2. Determination of the binding properties of the prodigiosins and tambjamines and their metal complexes with DNA.

3. Determination of the DNA cleavage activity of prodigiosins and tambjamines in the presence of metal ions. 


\subsection{Characterization, DNA Binding and Cleavage Activity of a new Metalloprodigiosin}

\section{Introduction}

The family of red pigments called prodigiosins or prodiginines has been studied extensively due to their biological activities. Earlier studies focused on the activity of the natural prodigiosins, but more recently synthetic analogues with enhanced antimalarial activity have been developed ${ }^{17,64}$. These analogues were found to have improved toxicological profiles, relative to chloroquine, in human liver hepatocellular carcinoma cell line (HepG2) as well as improved activity against chloroquine-sensitive, (D6) and chloroquine-resistant, (Dd2) and 7G8 strains of $P$. falciparum $^{12,64}$. Functionalized C-ring prodigiosins have been shown to have improved antimalarial, chloride transport and DNA cleavage activity ${ }^{12,65}$. The prodigiosins also show anti-cancer activity which is thought to be due to a combination of their $\mathrm{H}^{+} / \mathrm{Cl}^{-}$transport and their ability to bind to DNA and cause copper-mediated double-strand DNA cleavage ${ }^{19,66}$.

Transition metals play an important role in medicinal biochemistry. Metal containing compounds have been used to treat a variety of diseases or as diagnostic tools and also as anticancer agents ${ }^{67} \cdot 68$. The human body itself has metal-containing macromolecules that include iron (hemoglobin), molybdenum (xanthine oxidase), zinc (carbonic anhydrase, superoxide dismutase), and copper (hepatocuprein, superoxide dismutase). Interest in the use of metal complexes to treat disease was greatly increased after the success of cisplatin in cancer 
treatment ${ }^{69}$. In addition to cisplatin, there are a variety of non-platinum containing pharmaceuticals in use containing metal ions such as zinc(II), copper(II), ruthenium and gold ${ }^{70,71}$.

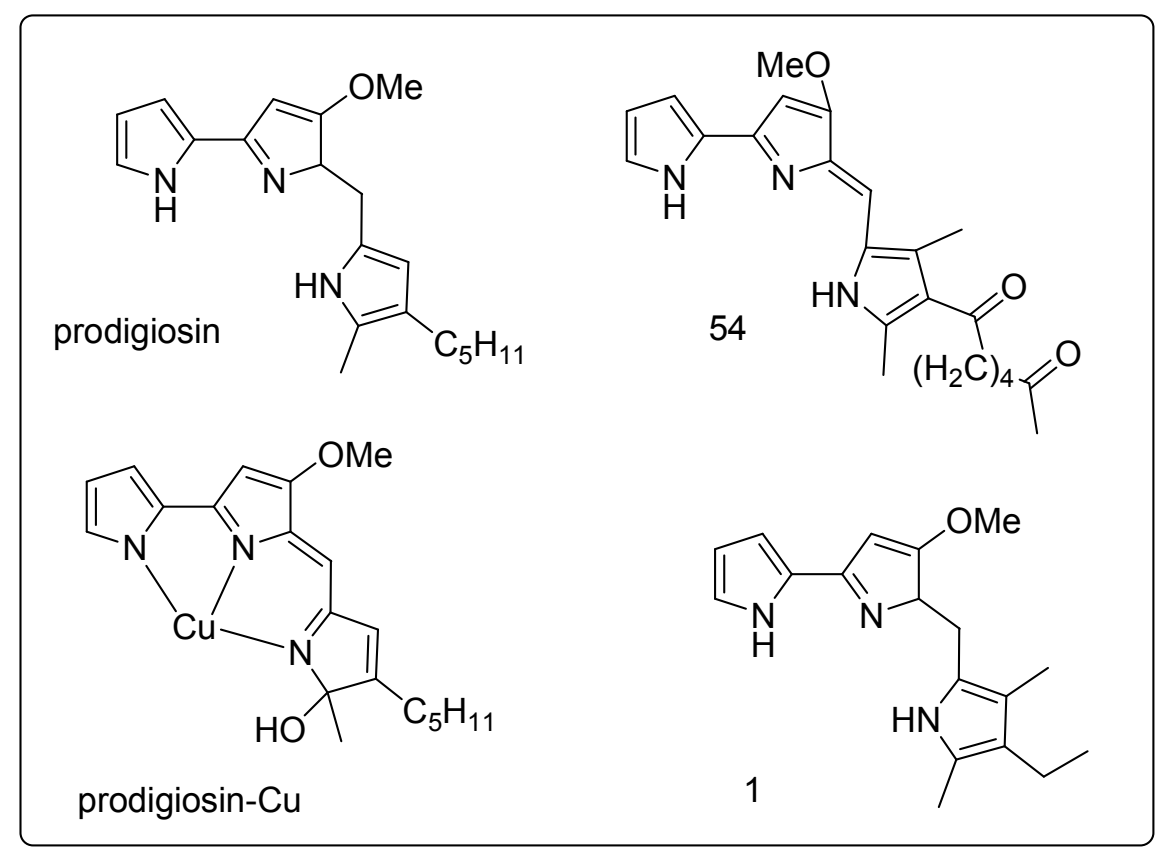

Figure 18. Structure of prodigiosin, a prodigiosin $\mathrm{Cu}$ complex and new prodigiosin analogues; 54 and 1.

Prodigiosins have previously been shown to form complexes with copper and zinc and Park et al., reported the formation of a 1:1 square planar complex with an oxidized C-ring, formed by the reaction of prodigiosin and $\mathrm{Cu}^{2+}$ under basic conditions ${ }^{25}$. One analogue of prodigiosin, 54 (figure 18), was also shown to bind $\mathrm{Cu}^{2+}$ and $\mathrm{Zn}^{2+}$ although the $\mathrm{Cu}^{2+}$ complex could not be isolated ${ }^{72}$. Prodigiosin has also been shown to efficiently bind DNA and facilitate oxidative DNA cleavage in the presence of $\mathrm{Cu}(\mathrm{II})$. This DNA cleavage occurs without the need of an added reductant in a mechanism that is dependent on oxidation of the electron-rich 
pyrrolylpyrromethene moiety ${ }^{66}$. In this work we investigated the interaction of a prodigiosin analogue, 1 (figure 18), with $\mathrm{Cu}^{2+}$ and showed that 1 forms a metalloprodigiosin complex $(\mathbf{1} \cdot \mathbf{C u})$ which is oxidized on the C-pyrrole ring and is able to bind to and cleave DNA.

\section{Experimental}

\section{Synthesis of 1}

The synthesis of $\mathbf{1}$ was achieved through acid-catalyzed condensation of commercially available 3-ethyl-2,4-dimethylpyrrole with a bipyrrole (Scheme 2 below). The bipyrrole was synthesized from Suzuki cross coupling between bromo pyrrole enamine (synthone 1) and Boc-pyrrole boronic acid under reflux, yielding the bipyrrole aldehyde (synthone 2$)^{12,73}$.

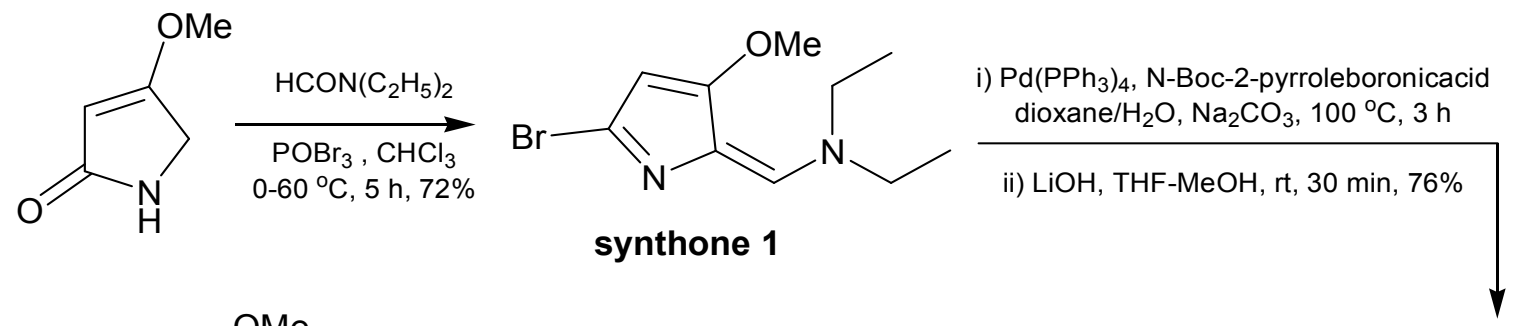<smiles>[R]c1[nH]c(/C=C2\N=C(c3ccc[nH]3)C=C2OC)c([R])c1[R]</smiles>

$\mathrm{R}_{1}-\mathrm{R}_{3}=$ alkyl(aryl) substituents

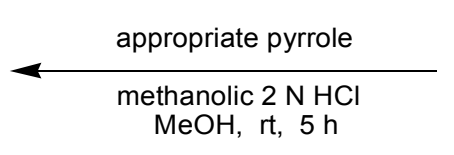

Prodiginines<smiles>COc1cc(-c2ccc[nH]2)[nH]c1C=O</smiles>

synthone 2

Scheme 2. Synthesis of prodiginine analogues. For $1, \mathrm{R}_{1}=\mathrm{CH}_{3}, \mathrm{R}_{2}=\mathrm{CH}_{2} \mathrm{CH}_{3}, \mathrm{R}_{3}=$ $\mathrm{CH}_{3}$. 


\section{Synthesis of the $\mathrm{Cu}^{2+}$ complex}

The metalloprodigiosin was synthesized as previousy described ${ }^{25}$. To a red solution of prodigiosin analogue, $1,(25 \mathrm{mg}, 0.1 \mathrm{mmol})$ in tertiary butanol, 3 equivalents of potassium tert-butoxide $(35 \mathrm{mg}, 0.3 \mathrm{mmol})$ in tertiary butanol were added, and then added a DMSO solution (2 equivalents) of $\mathrm{CuCl}_{2} \cdot 2 \mathrm{H}_{2} \mathrm{O}(35 \mathrm{mg}$, $0.2 \mathrm{mmol}$ ). The solution was stirred for $3-4$ hours at room temperature and then concentrated under diminished pressure. The solid was extracted with ethyl ether to give a dark purple solution, washed with pentane and dissolved in ethyl acetate. The resulting purple colored complex $(\mathbf{1} \cdot \mathbf{C u})$ was characterized by ESI-MS and ${ }^{1} \mathrm{H}-\mathrm{NMR}$.

\section{DNA}

Calf thymus DNA (CT-DNA) was purchased from Sigma Aldrich chemicals, USA and prepared by dissolving $1 \mathrm{mg}$ in $2 \mathrm{ml}$ of buffer ( $4 \mathrm{mM}$ sodium phosphate, 50 $\mathrm{mM} \mathrm{NaCl}, \mathrm{pH}$ 7.8) overnight before use. The purity of CT-DNA was determined by monitoring UV absorbance at $260 \mathrm{~nm}$ and $280 \mathrm{~nm}$. The $A_{260} / A_{280}$ ratio was found to be between $1.8-1.9$, suggesting that the sample was sufficiently free from protein impurities ${ }^{74}$. DNA concentration was determined by UV spectrophotometry using $\varepsilon=6600 \mathrm{Mcm}^{-1}$ at $260 \mathrm{~nm}$.

Plasmid DNA was prepared from transformation of $E$. coli Mach1 cells (Life Technologies) with pUC19 DNA. The cells were grown in Luria-Bertani medium for 12-16h. Plasmid DNA was then purified using a modified protocol of a 
commercially available Omega-Biotek E.Z.N.A plasmid purification kit as described by Carbone et al75. The purification of plasmid DNA with this method ensured isolation of almost $100 \%$ of the plasmids in supercoiled form.

\section{DNA binding activity}

Absorption titration experiments were performed on $\mathbf{1} \cdot \mathbf{C u}$ complex $(80 \mu \mathrm{M})$ in 4 $\mathrm{mM}$ sodium phosphate buffer, $50 \mathrm{mM} \mathrm{NaCl}, \mathrm{pH} 7.8$ while varying concentrations of the CT-DNA $(0-80 \mu \mathrm{M})$. Spectra were recorded on a Shimadzu 1700 UV-visible spectrophotometer using $1 \mathrm{~cm}$ quartz cuvettes. The binding constant, $\left(\mathrm{K}_{\mathrm{b}}\right)$ was

determined from the ratio of the slope to the intercept from a plot of $[D N A] /\left(\varepsilon_{a}-\varepsilon_{f}\right)$ vs [DNA]; where: $\varepsilon_{a}$ is the apparent extinction coefficient calculated by $A_{o b s d} /[C u]$ and $\varepsilon_{f}$ is the extinction coefficient of the free (unbound) complex determined using a calibration curve of an isolated $\mathbf{1} \cdot \mathbf{C u}$ complex, with the Beer-Lambert law ${ }^{76}$.

\section{DNA cleavage}

Concentration dependent cleavage of pUC19 DNA

Agarose gel electrophoresis experiments were performed with pUC19 DNA in 4 $\mathrm{mM}$ sodium phosphate buffer, $50 \mathrm{mM} \mathrm{NaCl}, \mathrm{pH}$ 7.8. DNA was incubated with 1·Cu in the presence and absence of $\mathrm{H}_{2} \mathrm{O}_{2}$ at $37^{\circ} \mathrm{C}$ for $1 \mathrm{hr}$. The reaction was quenched by adding $3 \mu \mathrm{L}$ loading buffer $(0.03 \%$ bromophenol blue, $0.03 \%$ xylene cyanol $\mathrm{FF}$, $60 \%$ glycerol, $60 \mathrm{mM}$ EDTA). The samples were electrophoresed at $70 \mathrm{~V}$ for $1.5 \mathrm{hr}$ on a $0.8 \%$ agarose gel using tris-acetate-EDTA (TAE) buffer then stained with 
ethidium bromide. DNA cleavage was visualized using the Typhoon $\mathrm{Trio}^{+}$variable mode Imager (GE Healthcare) to measure the different isomers of pDNA.

Assesment of DNA cleavage in the presence of antioxidants

Plasmid DNA in $4 \mathrm{mM}$ sodium phosphate buffer, $50 \mathrm{mM} \mathrm{NaCl}, \mathrm{pH} 7.8$ was incubated with $1 \cdot \mathrm{Cu}$ in the presence of different antioxidants: $\mathrm{NaN}_{3}$, DMSO, EDTA, CAT and SOD at $37^{\circ} \mathrm{C}$ for $1 \mathrm{hr}$. The reaction was quenched by adding $3 \mu \mathrm{L}$ loading buffer $(0.03 \%$ bromophenol blue, $0.03 \%$ xylene cyanol FF, $60 \%$ glycerol, $60 \mathrm{mM}$ EDTA). The samples were electrophoresed at $70 \mathrm{~V}$ for $1.5 \mathrm{hr}$ on a $0.8 \%$ agarose gel using tris-acetate-EDTA (TAE) buffer then stained with ethidium bromide. DNA cleavage was visualized using the Typhoon $\mathrm{Trio}^{+}$variable mode Imager (GE Healthcare).

\section{Results}

\section{UV-Vis titration and MS analysis}

In order to establish if the prodigiosin analogue, $\mathbf{1}$, interacts with $\mathrm{Cu}^{2+}$ a UV-Vis titration was carried out with $20 \mu \mathrm{M} 1$ adding 0.1 equivalents of $\mathrm{Cu}(\mathrm{OAc})_{2}$ every 10 mins at room temperature in $\mathrm{MeOH}$ containing $10 \mathrm{mM}$ tert-butoxide/acetic acid, $\mathrm{pH}$ 10. Figure 19 shows a concentration dependent disappearance of the absorbance of free analogue 1 at $470 \mathrm{~nm}$ with concurrent gain of absorbance at 550-600 nm suggesting formation of $1 \cdot \mathrm{Cu}$ complex. 


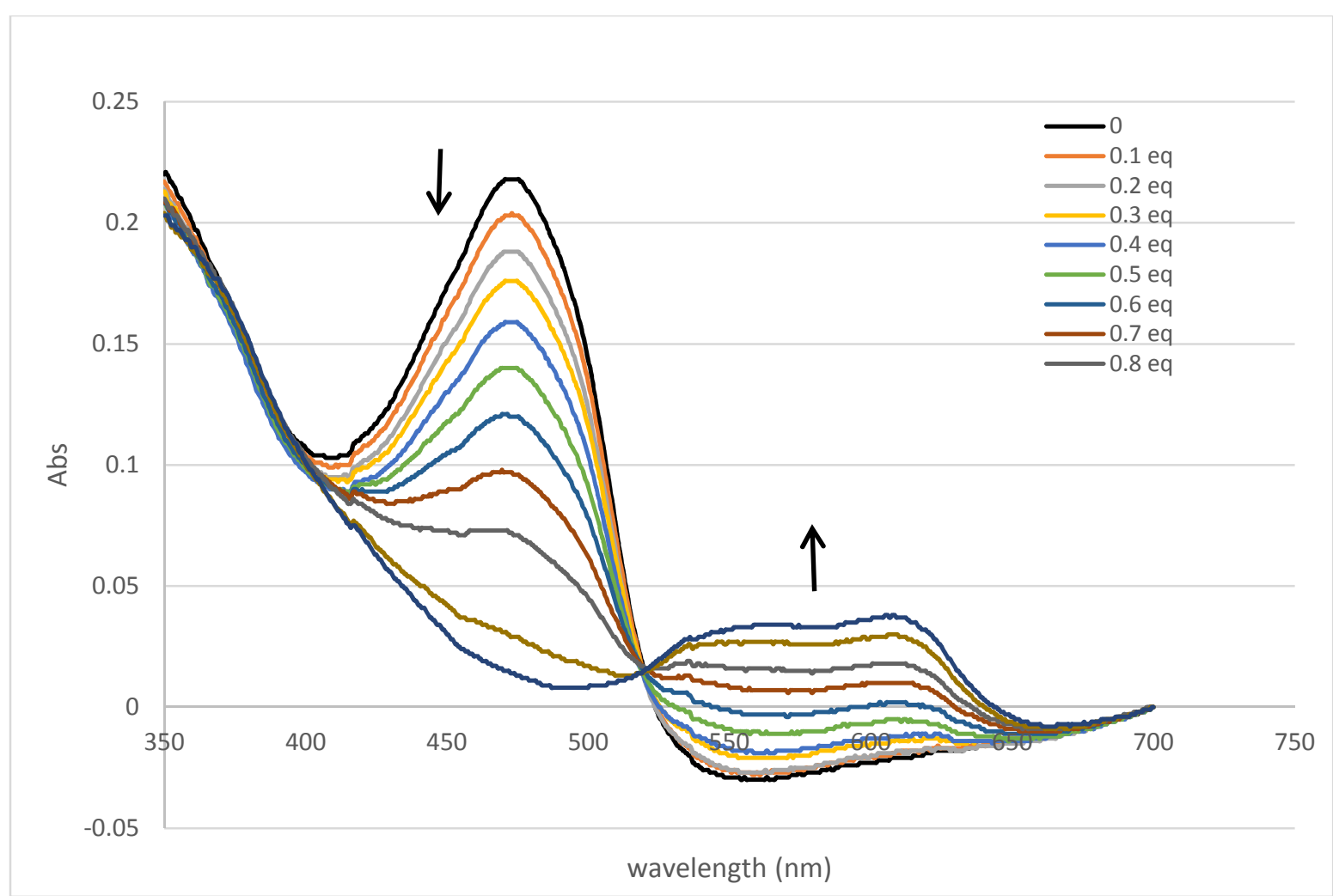

Figure 19. UV-vis analysis of a titration of $1,20 \mu \mathrm{M}$ vs $\mathrm{Cu}(\mathrm{OAc}) 2$ 0.1-1.0 equivalents.

To confirm formation of a complex, the titration was repeated in a $90 \%$ methanol solution. The $t$-butoxide was omitted in these experiments to allow for subsequent mass spectrometric analysis. The red solution of $\mathbf{1}$ turned purple on addition of $\mathrm{Cu}(\mathrm{OAc})_{2}$ (figure 20 top panel) and MS analysis of the resulting solution revealed a peak at $\mathrm{m} / \mathrm{z}=355.07$ suggesting formation of a $\mathrm{Cu}$ complex with the possible structure shown in figure 20 below: 

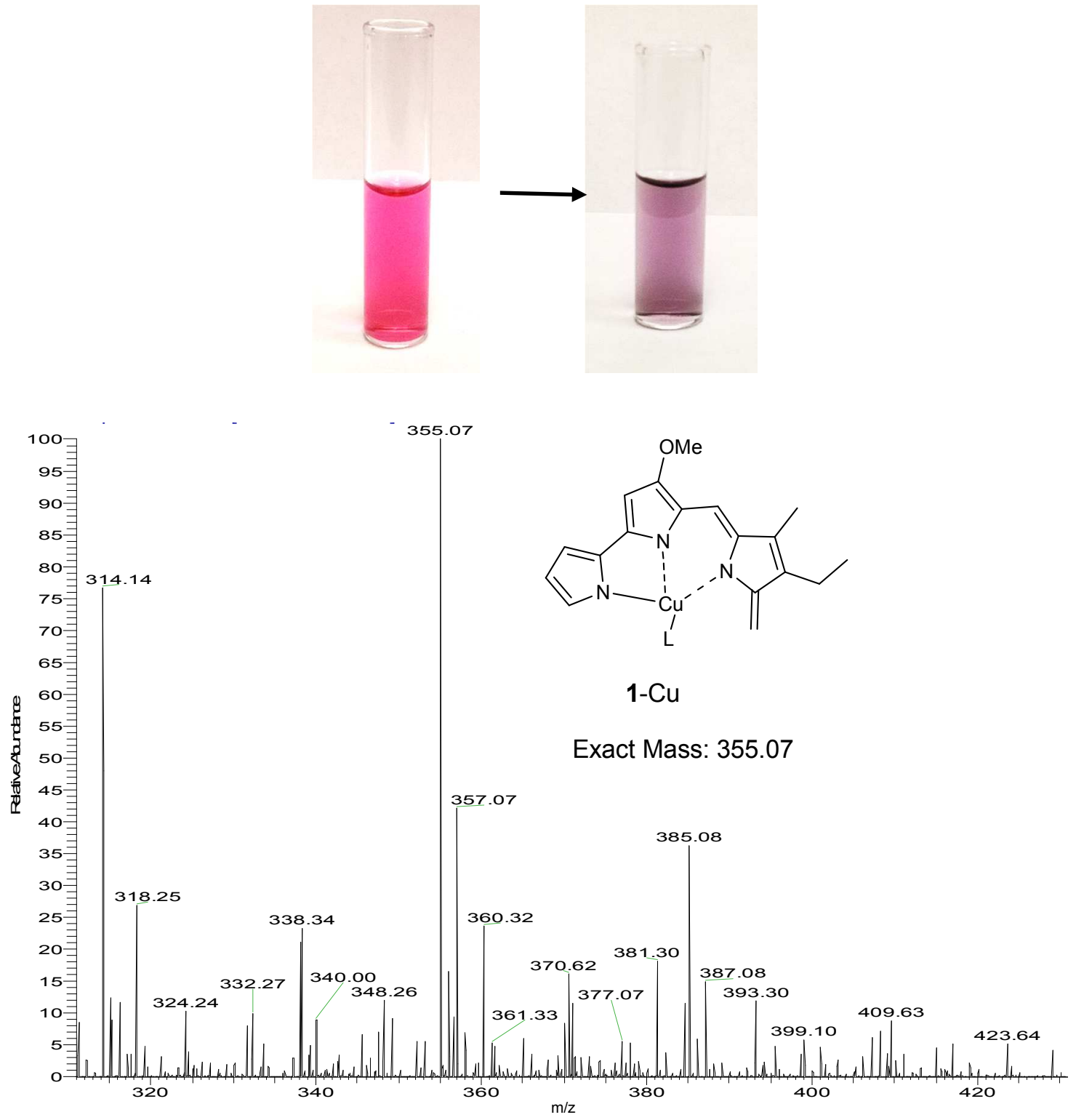

Figure 20. The color change observed when $\mathrm{Cu}(\mathrm{OAc})_{2}$ is added to a solution of 1 (top panel). ESI-MS analysis of $1 \cdot \mathbf{C u}$ complex formation in $90 \% \mathrm{MeOH}$ solution (bottom panel). 


\section{Characterization of 1·Cu complex}

The 1.Cu complex was prepared as previously described and further analyses were conducted without additional purifications owing to complications with purification methods. The progress of the reaction was monitored by UV-Vis and TLC (figure 21). Since both $\mathbf{1}$ and $\mathbf{1 \cdot C u}$ are colored red and purple respectively; they were observed directly on the TLC plate. Furthermore, MS and ${ }^{1} \mathrm{H}$ NMR studies and side by side comparison with 1 were carried out to elucidate the structure of 1·Cu complex (Figure 22, and 23). (Figure 21, top panel).

A

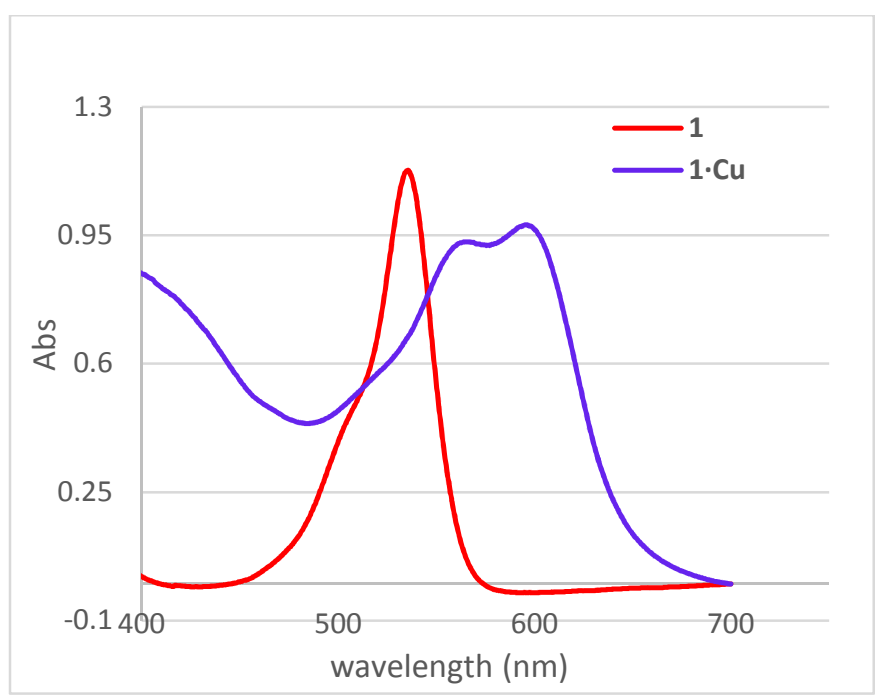

B

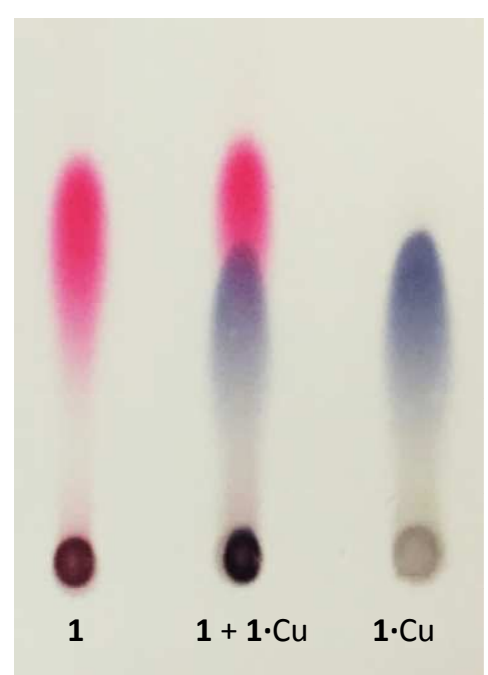

Figure 21. UV-Vis profile of $1 \lambda_{\max } 535 \mathrm{~nm}$ and $1 \cdot \mathrm{Cu} \lambda_{\max } 596 \mathrm{~nm}(\mathrm{~A})$ and TLC characterization of $\mathbf{1}$ and 1.Cu (40:60; Ethyl acetate:hexanes) (B). 
The high resolution mass spectrum showed a molecular ion peak at $355.0731[\mathrm{M}]^{+}$ and this molecular ion is very similar to the calculated mass $(355.0740)$ that unambiguously suggests the formation of $\mathrm{Cu}$ complex with prodiginine 1 (figure 22). The isotopes of $\mathrm{Cu} ;{ }^{63} \mathrm{Cu}$ and ${ }^{65} \mathrm{Cu}$ occur naturally at approximately $70: 30$ abundance which are apparent in the observed MS isotope pattern. The MS data suggests formation of $1: 1 \mathrm{1} \cdot \mathrm{Cu}$ complex and this is consistent with what was previously reported for prodigiosin ${ }^{77}$.

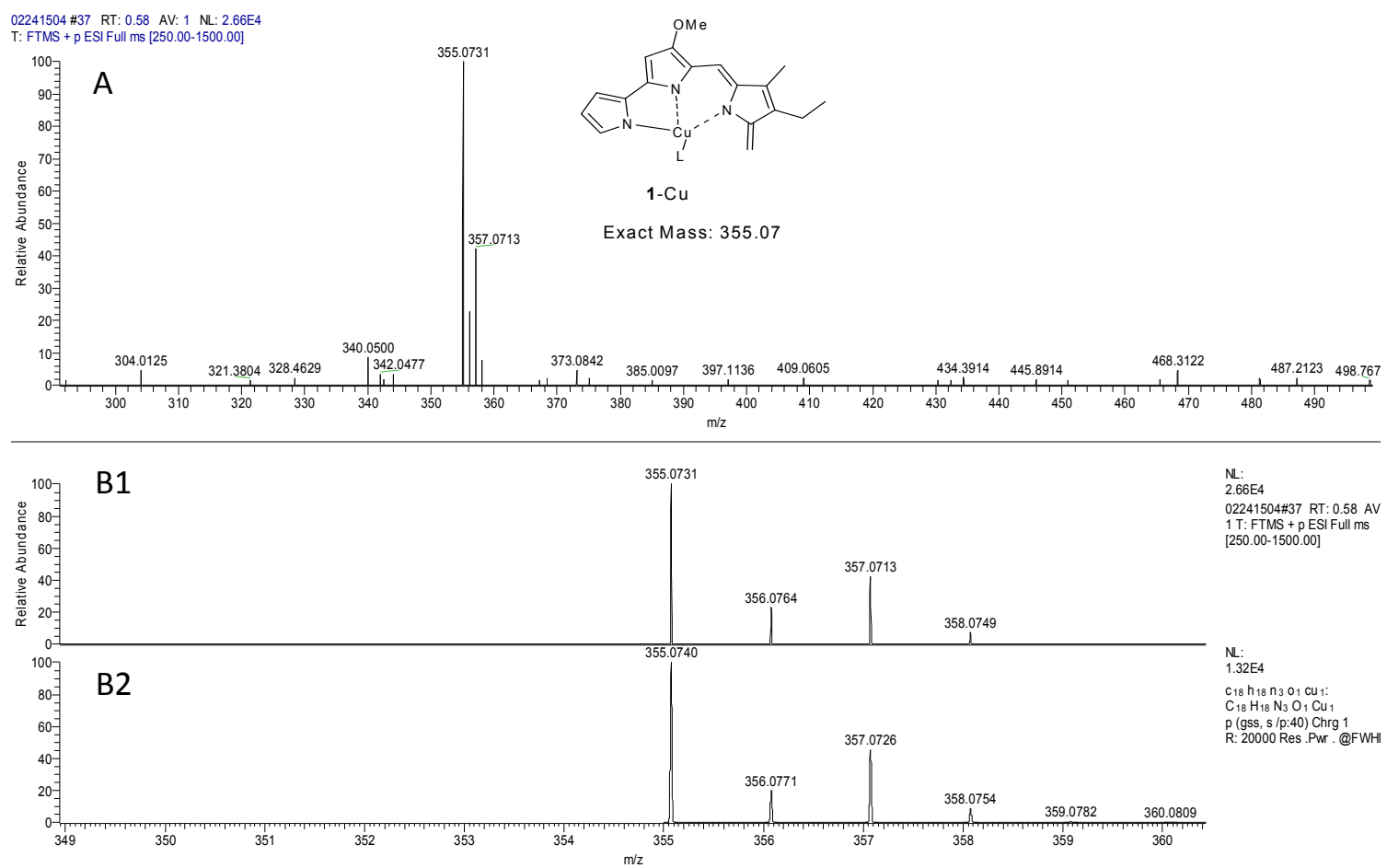

Figure 22. ESI-MS analysis of 1. Cu complex (top panel) and a comparison of the $\mathrm{MS}$ isotope patterns on 1.Cu with isotope simulation (bottom panel). 
NMR characterization of $1 \cdot \mathrm{Cu}$ was carried out on a $400 \mathrm{MHz}$ NMR spectrometer. A comparison of the proton NMR spectra for $\mathbf{1}$ with that of $\mathbf{1} \cdot \mathrm{Cu}$ reveals that $\mathbf{1}$ has five aromatic protons with chemical shift $\delta 6-7.3 \mathrm{ppm}$, while $1 \cdot \mathrm{Cu}$ shows seven aromatic protons with chemical shift $\delta 5.0-7.0 \mathrm{ppm}$ range corresponding to the 7 aromatic protons expected in $\mathbf{1} \cdot \mathbf{C u}$.

One of the significant differences in the ${ }^{1} \mathrm{H}$ NMR spectra of 1 and $1 \cdot \mathrm{Cu}$ is the appearance of two extra olefinic singlets at 5.03 and $5.13 \mathrm{ppm}$ in addition to the five aromatic protons in 1. $\mathbf{C u}$ (Figure 22). These olefinic protons are characteristic to the exocyclic olefinic bond as in the $1 \cdot \mathbf{C u}$ complex. The rest of the five aromatic protons appear in the aromatic region, with exception of one proton that merged with one of the exocyclic olefinic protons.

The methoxy group on the middle pyrrole ring is significantly shifted to the upfield region. Since the $\mathrm{Cu}^{2+}$ is paramagnetic, this causes poor resolution of the spectra such that most of the aromatic and aliphatic protons appear as broad singlets. 


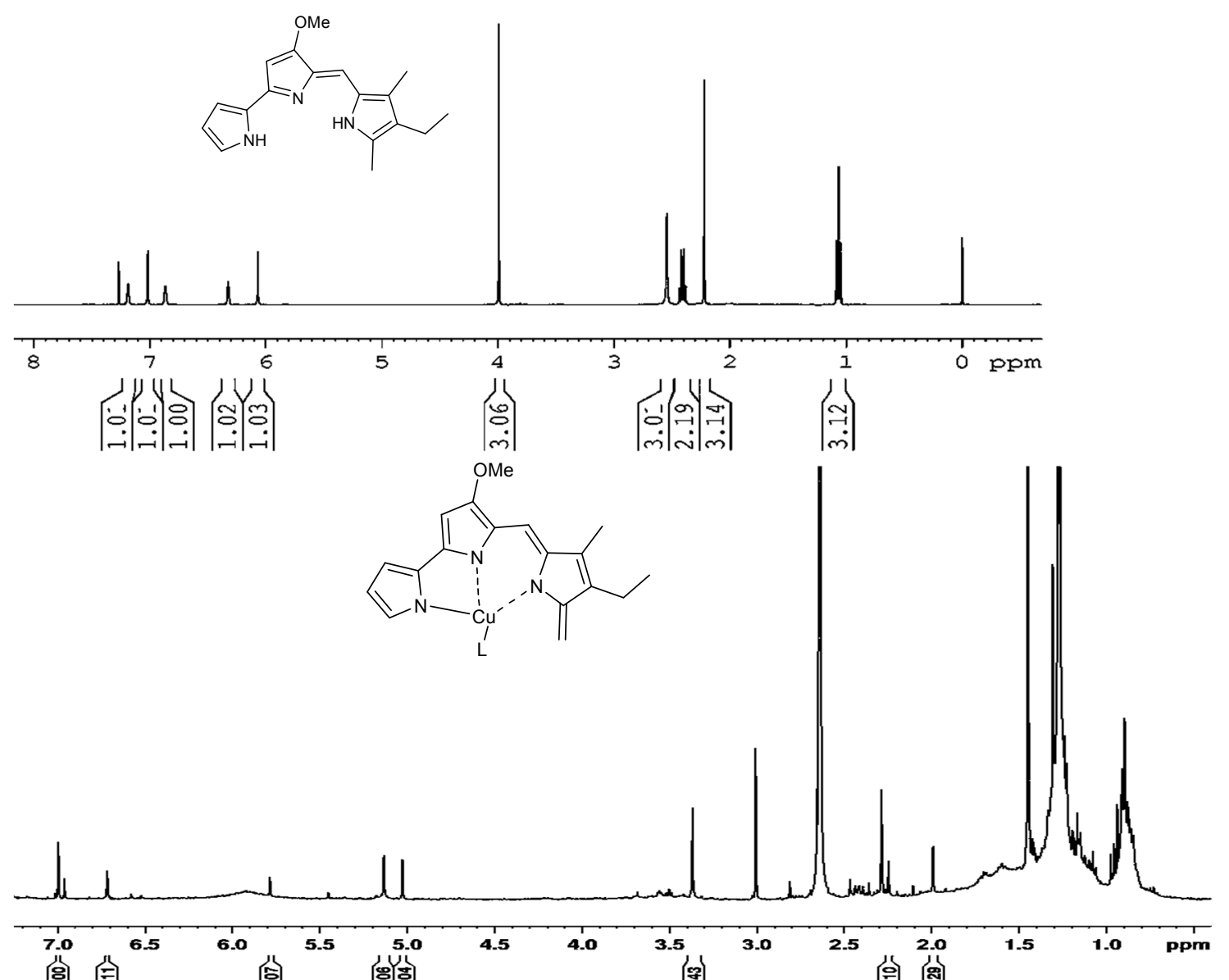

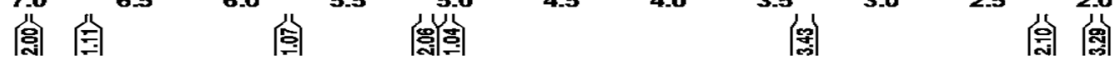

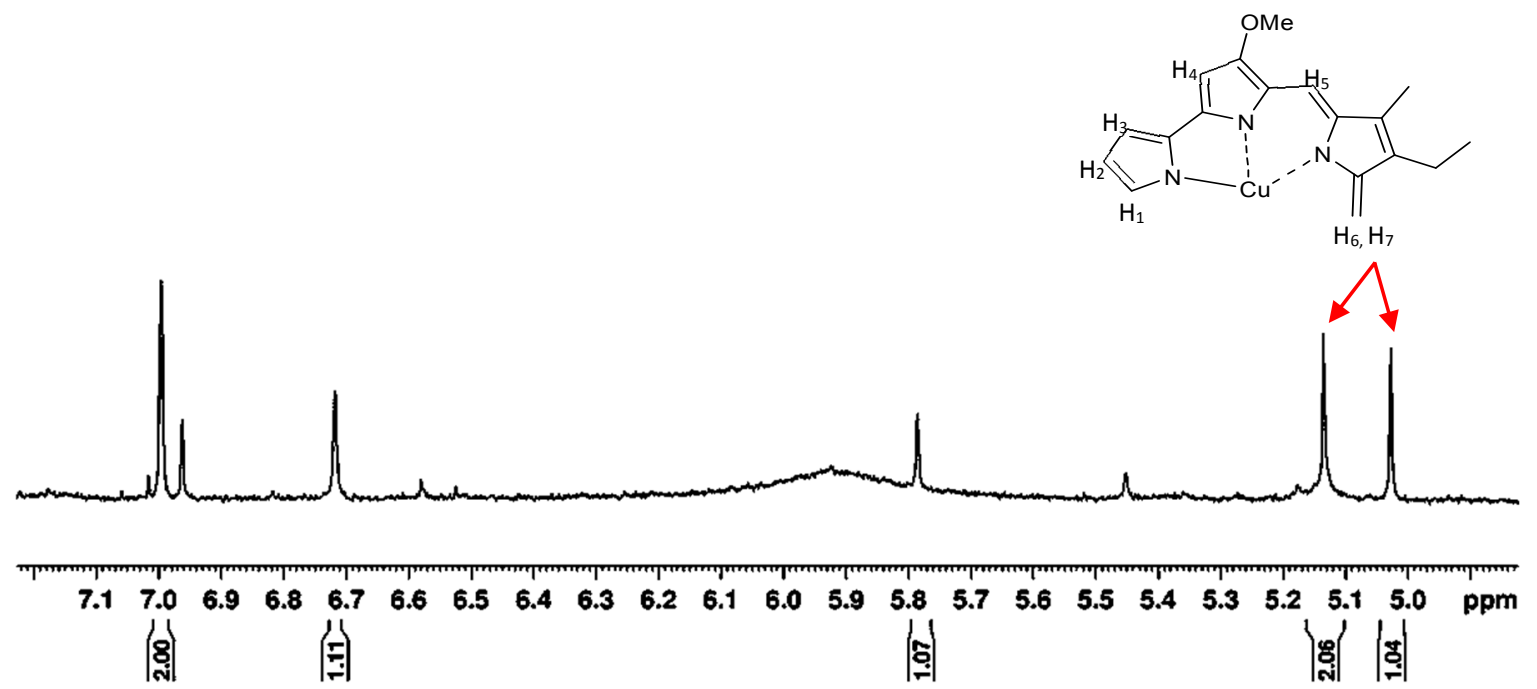

Figure 23. ${ }^{1} \mathrm{H}$ NMR spectral $\left(400 \mathrm{MHz}, \mathrm{CDCl}_{3}\right)$ analysis. Top panel represents the ${ }^{1} \mathrm{H}$ NMR of prodigiosin analogue, 1 , middle panel represents the ${ }^{1} \mathrm{H}$ NMR of the complex $1 \cdot \mathbf{C u}$, and bottom panel represents the expansion of olefinic and aromatic regions of $\mathbf{1} \cdot \mathrm{Cu}$. 


\section{Cu complex is reversible}

An EDTA chelation experiment showed that the 1·Cu complex formed is reversible (Figure 24). In the presence of excess EDTA there is a loss in absorbance of $\mathbf{1} \cdot \mathbf{C u}$ complex at $600 \mathrm{~nm}$ accompanied by an increase in absorbance at about $500 \mathrm{~nm}$. Spectral changes in the absorbance of the 1.Cu complex were observed within the first minute of EDTA addition with disappearance of the peak at about $600 \mathrm{~nm}$. There was a gradual increase in absorption at about $500 \mathrm{~nm}$ over time. This observation suggests that the $\mathbf{1} \cdot \mathbf{C u}$ complex is reversible and immediately forms a complex with EDTA. However, the fact that we do observe the ternary $1 \cdot \mathbf{C u}$ EDTA complex by mass spectrometry, after several minutes, suggests that the 1. Cu complex is quite stable as EDTA does not immediately chelate the $\mathrm{Cu}^{2+}$ from the complex. The gradual appearance of a new peak at 500nm over an hour suggests that the dissociation of the $1^{*}$ from the $1 \cdot$ Cu-EDTA complex occurs at a much slower rate than the formation of the 1-Cu-EDTA complex. In addition, the free $1^{*}$ has a maximum absorbance at $500 \mathrm{~nm}$, while the parent 1 compound absorbs at $535 \mathrm{~nm}$. This observation suggests that there is a change in the structure of the parent ligand when it forms a complex with $\mathrm{Cu}^{2+}$, consistent with the NMR analysis, and although EDTA chelates $\mathrm{Cu}^{2+}$ it does not revert back to the original structure. 


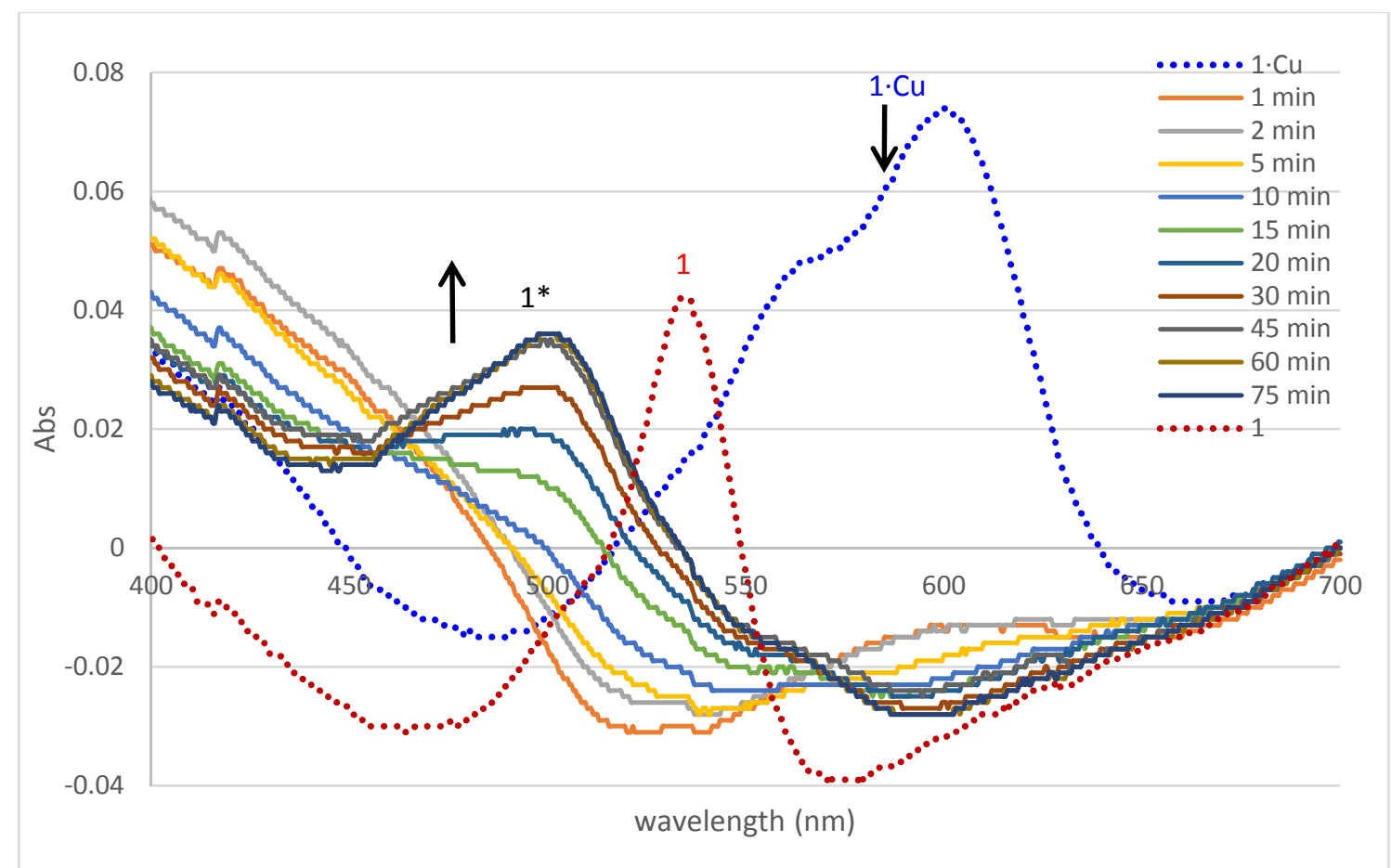

Figure 24. Spectral changes observed in the UV-Vis spectrum of $100 \mu \mathrm{M} 1 \cdot \mathrm{Cu}$ on addition of excess EDTA over 75 mins at room temperature.

The formation of this complex was confirmed by ESI-MS characterization of the chelation process (figure 25). The data from the MS experiment shows that the EDTA forms a complex with the 1.Cu with a $\mathrm{m} / \mathrm{z}$ of 689 which then dissociates into EDTA-Cu and free hydroxylated or methoxylated $1^{*}(\mathrm{~m} / \mathrm{z} 311$ and 325$)$ (figure 26$)$. This is further evidence in support of the oxidation of the C-ring of prodigiosins during complex formation. 


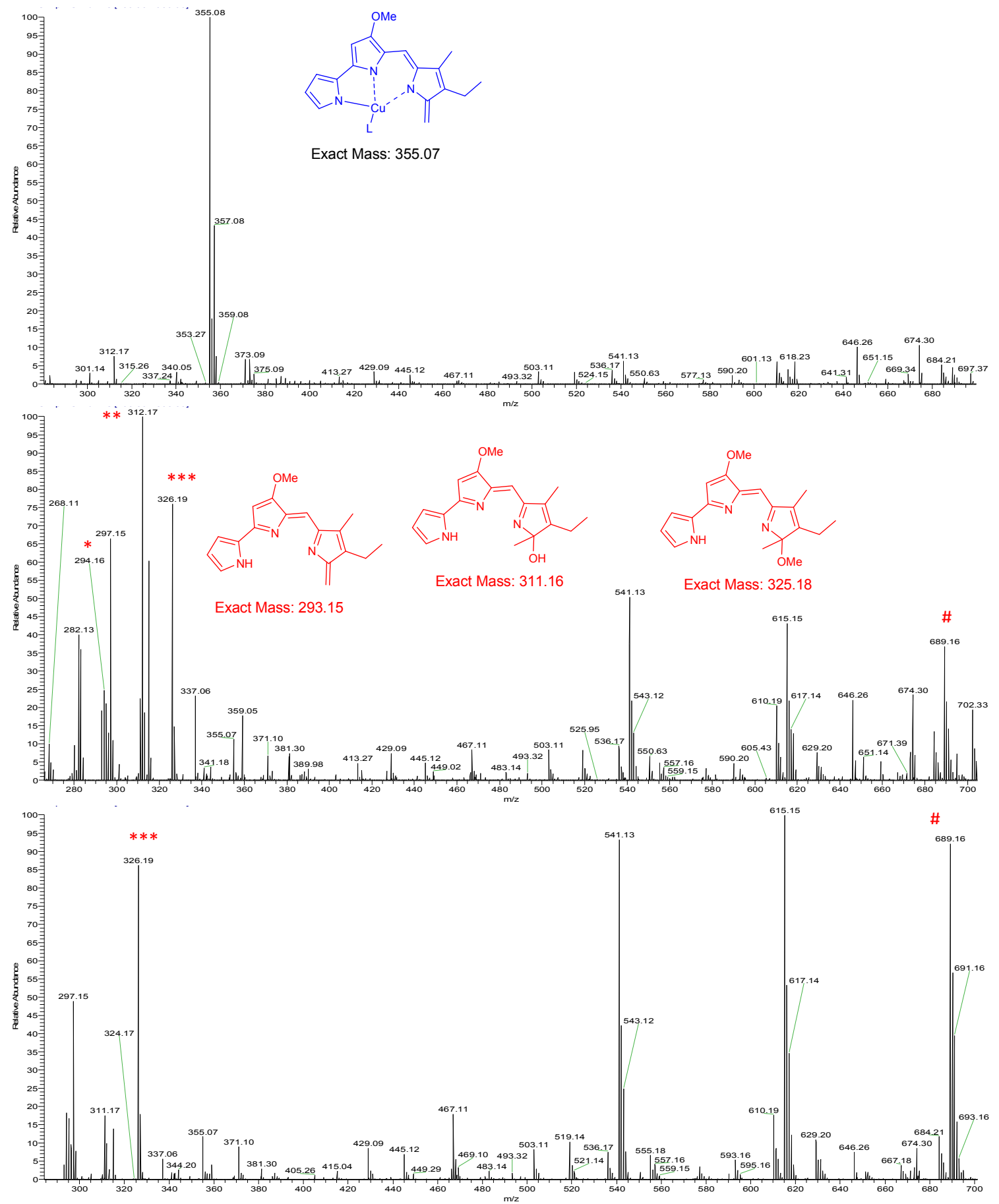

Figure 25. ESI-MS analysis of $\mathrm{Cu}^{2+}$ chelation from 1. Cu by EDTA; time $=0$ min (top panel), time $=5 \mathrm{~min}$ (middle panel) and time $=60 \mathrm{~min}$ (bottom panel). 


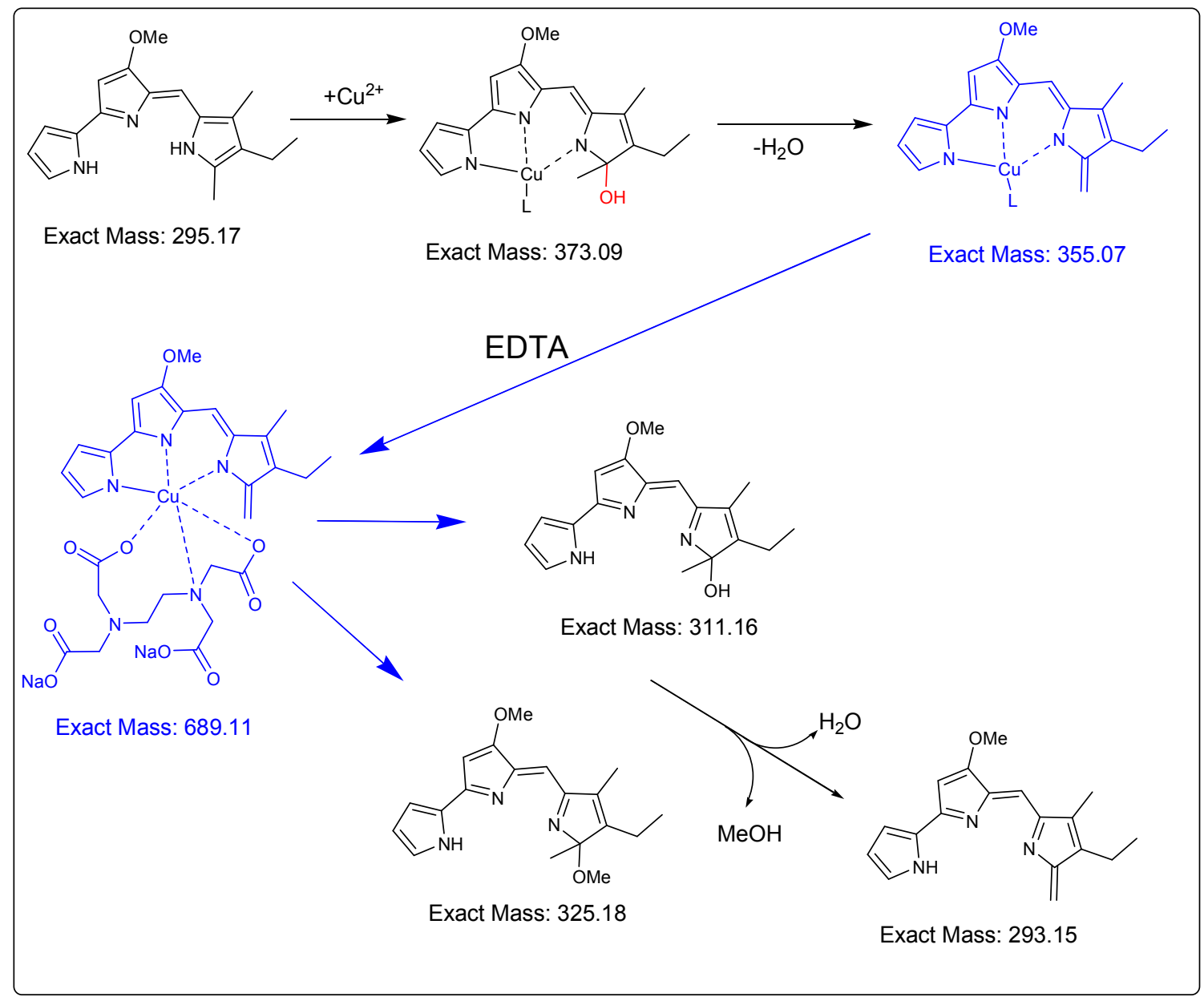

Figure 26. ESI-MS analysis revealed that EDTA chelates $\mathrm{Cu}^{2+}$ from 1. $\mathrm{Cu}$ complex through a mechanism involving formation of a 1.Cu -EDTA intermediate before releasing free $1^{*}$ and EDTA-Cu. 


\section{DNA Binding Studies}

To determine if the free prodigisoin analogue, $\mathbf{1}$, and the copper complex $\mathbf{1} \cdot \mathbf{C u}$ interact with DNA; a fixed concentration of the analogue or the $\mathrm{Cu}^{2+}$ complex was incubated with varying concentrations of CT-DNA for 1 hour at $37^{\circ} \mathrm{C}$. Hyperchromism of about $28 \%$ was observed in the absorbance of 1 when incubated with increasing concentrations $(0-80 \mu \mathrm{M})$ of CT-DNA in the absence of metal ion and $9 \%$ hyperchromism in the presence of $\mathrm{Zn}^{2+}$ (Figure 27). The extent of hyperchromism is indicative of partial or non-intercalative binding modes, such as electrostatic forces between the $\mathrm{Cu}^{2+}$ and the negatively charged phosphate groups on the DNA backbone, van der Waals interaction or hydrogen bonds. Since 1 is assumed to be planar, it would be expected to intercalate between the base pairs of DNA. However, the data does not support this mode of interaction. It is possible that hydrogen bonding is a more favorable interaction, because DNA possesses several hydrogen bonding sites which are accessible, and 1 possesses amine $(\mathrm{NH})$ groups in the pyrrole rings which can interact with the hydrogen bonding sites on CT-DNA. 


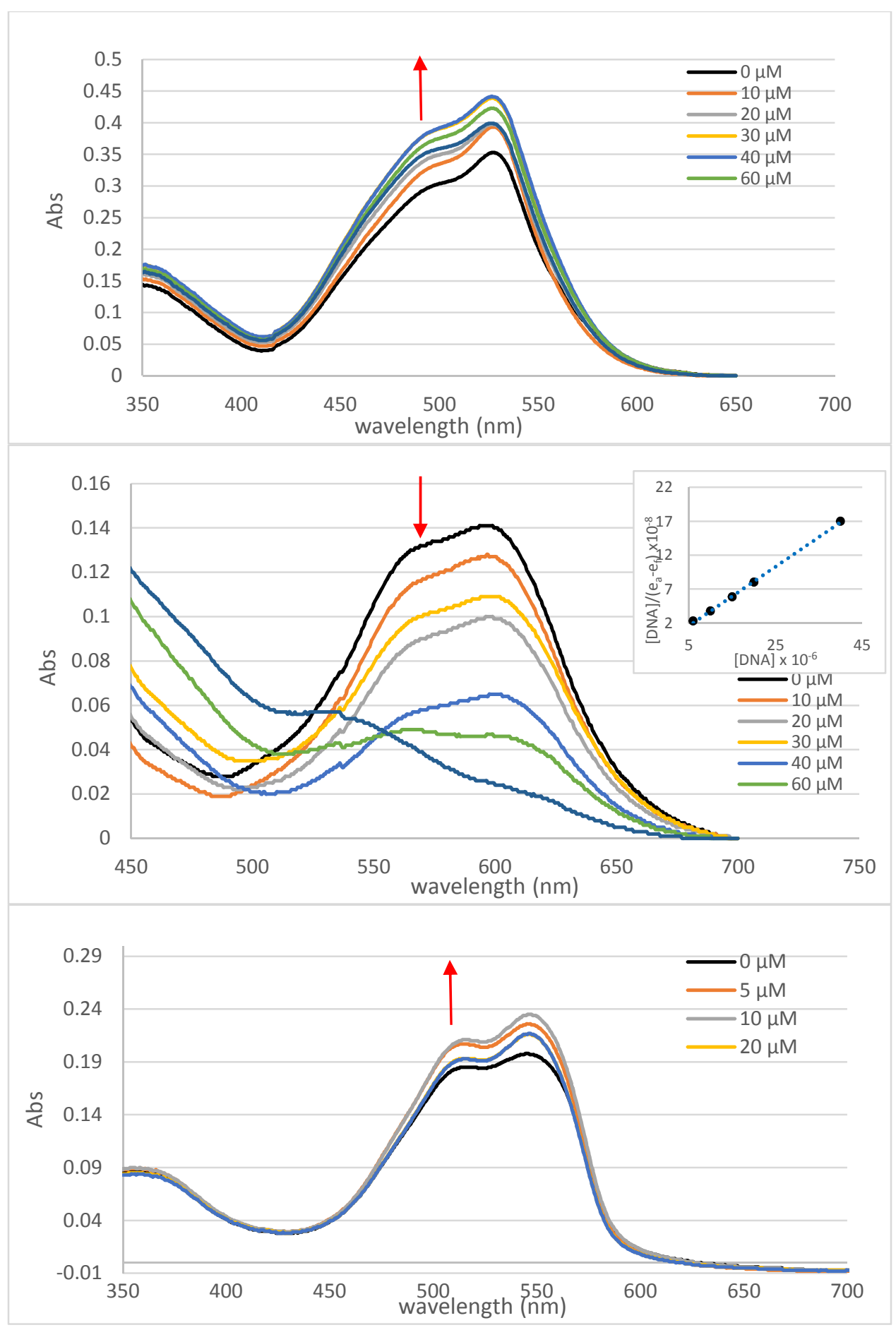

Figure 27. Interaction of 1 with CT-DNA results in an increase in absorption of the prodigiosin analogue in the absence (top panel) and presence of $\mathrm{Zn}^{2+}$ and a decrease in the absorption of 1.Cu complex (middle panel) with increasing CTDNA $(0-80 \mu \mathrm{M})$. Inset: Plot of $[\mathrm{DNA}] /\left(\varepsilon_{\left.\mathrm{a}-\varepsilon_{\mathrm{f}}\right)}\right)$ vs [DNA] for the interaction of $\mathbf{1} \cdot \mathbf{C u}$ with DNA. 
In the experiment with $\mathbf{1} \cdot \mathbf{C u}$ increasing the concentration of CT-DNA resulted in hypochromism of about $76 \%$ at $80 \mu \mathrm{M}$ CT-DNA with no change in maximum absorption wavelength (Figure 27). These spectral shifts suggest that the 1.Cu complex binds to DNA by a stacking interaction mode. Intercalative mode involves stacking interactions between the complex and the base pairs of DNA. The $\pi^{*}$ orbital of the copper complex is partially filled by electrons from the $\pi$ orbitals of the DNA bases, resulting in a decrease in transitions in the complex which leads to the observed hypochromism ${ }^{78}$.

The binding constant was determined from the plot of $[\mathrm{DNA}] /\left(\varepsilon_{\mathrm{a}}-\varepsilon_{f}\right) v s[\mathrm{DNA}]$ (Figure 27 inset), using the absorption at $600 \mathrm{~nm}$. The calculated $\mathrm{K}_{\mathrm{b}}$ value for the 1. Cu complex is $4.1 \times 10^{6} \mathrm{M}^{-1}$. This $\mathrm{K}_{\mathrm{b}}$ is of the same order as that reported for ethidium bromide, a classical intercalator which has a $\mathrm{K}_{\mathrm{b}}$ value of $1.4 \times 10^{6} \mathrm{M}^{-1}$ suggesting that $1 \cdot \mathrm{Cu}$ also strongly binds to CT-DNA by intercalation ${ }^{79}$.

\section{DNA Cleavage}

The DNA cleavage ability of 1 in the presence of $\mathrm{Cu}^{2+}$ and $\mathbf{1} \cdot \mathrm{Cu}$ was determined by gel electrophoresis after a 1 -hour incubation at $37^{\circ} \mathrm{C}$. As shown in Figure 28 , at concentrations above $500 \mathrm{nM}, 1$ begins to show DNA nuclease activity which is dependent on the presence of both $\mathrm{Cu}^{2+}$ and $\mathrm{H}_{2} \mathrm{O}_{2}$, as absence of either of these eliminates the ability of $\mathbf{1}$ to cleave DNA (Figure 29). The copper complex, $\mathbf{1} \cdot \mathbf{C u}$ also exhibits DNA nuclease activity and converts supercoiled (form I) DNA into 
linear (form III) DNA (20-60\%) in a concentration dependent manner at $40-200$ $\mu \mathrm{M} 1 \cdot \mathrm{Cu}$ (figure 29). The nuclease activity does not occur when DNA is incubated with either preformed $\mathbf{1} \cdot \mathbf{C u}$ or $\mathbf{1 + C u}$ alone (Figure 29 lanes 6-8).

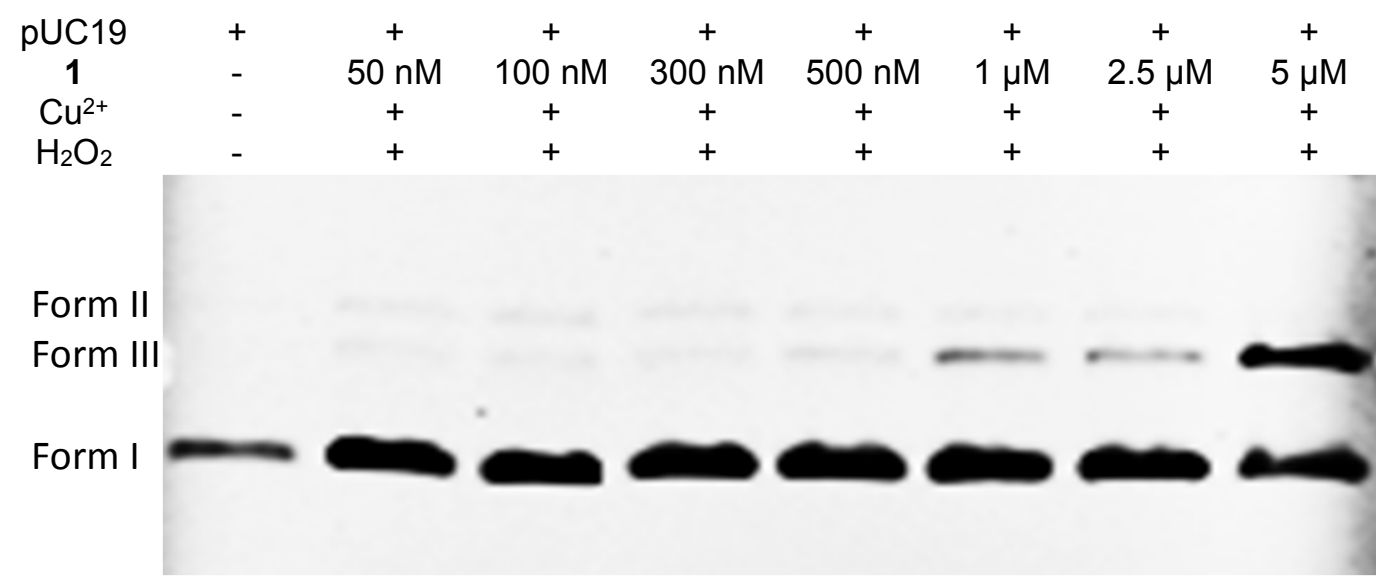

Figure 28. Gel shift analysis showing cleavage of $8.5 \mathrm{nM}$ pUC19 DNA in the presence of 1 and added equimolar $\mathrm{Cu}^{2+}$ and $25 \mu \mathrm{M} \mathrm{H}_{2} \mathrm{O}_{2}$ at $37^{\circ} \mathrm{C}$.

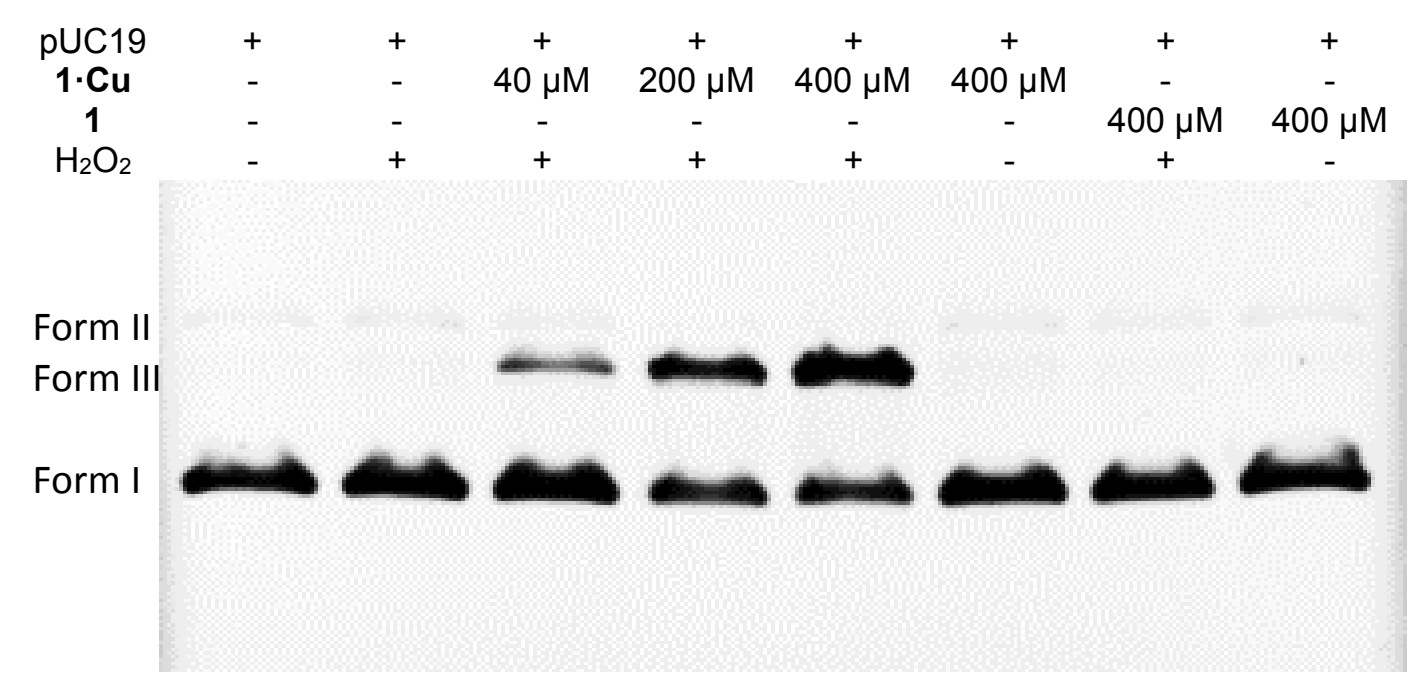

Figure 29. Gel shift analysis showing cleavage of $8.5 \mathrm{nM}$ pUC19 DNA in the presence of $1 \cdot \mathrm{Cu}$ at $37^{\circ} \mathrm{C}$. 
In order to gain some insight into the mechanism of the DNA cleavage activity of $\mu \mathrm{M} 1 \cdot \mathrm{Cu}$ a gel shift assay was carried out in the presence of $\mathrm{NaN}_{3}$, a singlet oxygen quencher; DMSO, a hydroxyl radical scavenger; EDTA, a metal chelator; catalase (CAT), a $\mathrm{H}_{2} \mathrm{O}_{2}$ decomposer, and $\mathrm{SOD}$, a superoxide anion scavenger (Figure 30 ). The addition of EDTA and CAT provides a protective effect against cleavage activity of $1 \cdot \mathrm{Cu}$ confirming the participation of the $\mathrm{Cu}^{2+}$ (as well as the $\mathrm{H}_{2} \mathrm{O}_{2}$ ) in the cleavage of DNA. However, $\mathrm{NaN}_{3}$, DMSO, and CAT do not protect DNA against cleavage suggesting that the mechanism of DNA cleavage might involve a shortlived hydroxyl radical (figure 31, Path A). Alternatively, 1 C Cu might form a Pg$\mathrm{Cu}-\mathrm{OOH}$ complex able to cause the DNA damage directly by attack on the phosphate group (Figure 31, Path B).

$\begin{array}{ccccccccc}\text { pUC19 } & + & + & + & + & + & + & + & + \\ 1 \cdot \mathrm{Cu} & - & - & 40 \mu \mathrm{M} & 40 \mu \mathrm{M} & 40 \mu \mathrm{M} & 40 \mu \mathrm{M} & - & - \\ \mathrm{H}_{2} \mathrm{O}_{2} & + & + & + & + & + & - & + & - \\ & & & \mathrm{NaN}_{3} & \text { DMSO } & \text { EDTA } & \text { CAT } & \text { SOD } & \end{array}$

Form II Form III Form I
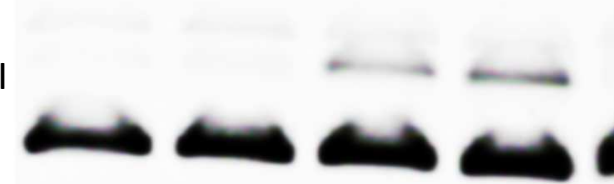

Figure 30. Gel shift analysis showing cleavage of $300 \mathrm{ng}(8.5 \mathrm{nM})$ pUC19 DNA in the presence of $1 \cdot \mathrm{Cu}+\mathrm{H}_{2} \mathrm{O}_{2}$ at $37^{\circ} \mathrm{C}$. 


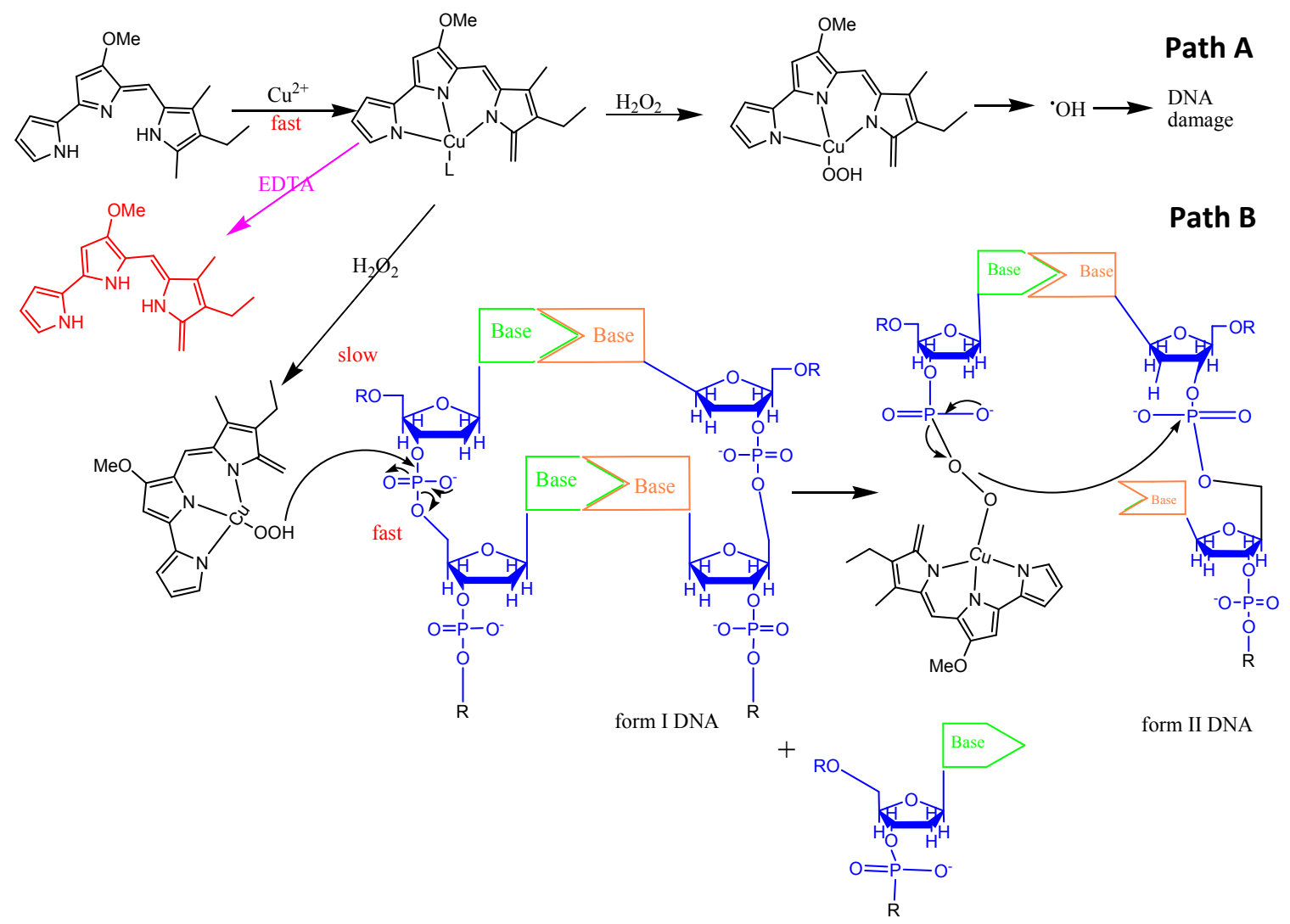

Figure 31. Proposed mechanism for DNA cleavage by $\mathbf{1 \cdot C u}$ can involves formation of a $\mathrm{Pg}-\mathrm{Cu}-\mathrm{OOH}$ complex that leads to formation of $\mathrm{OH}$ radical (Path $\mathrm{A}$ ) or nucleophilic attack of phosphate group (Path B). 


\section{Conclusion}

In this work, a new metalloprodigiosin, $\mathbf{1} \cdot \mathbf{C u}$, was synthesized and the resulting complex characterized by various methods. The DNA binding and cleavage activity of the copper complex has been evaluated. Although the prodigisin analogue, $\mathbf{1}$, interacts with DNA, it did not have DNA cleavage activity in the absence of $\mathrm{Cu}^{2+}$. NMR analysis of the copper complex shows the presence of a vinylic group. Previous studies of metalloprodigiosins have shown this group to be on $\mathrm{C}-1$ of the C-pyrrole ring of the complex, suggesting oxidation of the C-ring occurs during complex formation followed by dehydration to form the vinyl group ${ }^{25}$. The ESI-MS data also suggests formation of a 1:1 complex, and UV experiments and gel electrophoresis suggests that $\mathbf{1} \cdot \mathbf{C u}$ interacts with DNA through intercalation and in addition has DNA nuclease activity, causing double strand cleavage of supercoiled plasmid DNA in the presence of $\mathrm{H}_{2} \mathrm{O}_{2}$. Finally, we observed that the free analogue 1 interacts with DNA through a non-intercalative binding mode, possibly hydrogen bonding. 


\subsection{In situ Studies of $\mathrm{Cu}^{2+}$ and $\mathrm{Zn}^{2+}$ Complexes of Prodiginine and Tambjamine Analogues; DNA Binding and Cleavage Activity.}

\section{Introduction}

There has been increasing interest in the coordination chemistry of prodigiosins in an effort to explain their mechanism of action. In the previous chapter a new metalloprodigiosin, $1 \cdot \mathrm{Cu}$, was synthesized and shown to bind and cleave DNA in the presence of $\mathrm{H}_{2} \mathrm{O}_{2}$. Prodigiosins $(\mathrm{Pg})$ and tambjamines $(\mathrm{Tm})$ have been shown to form complexes of $\mathrm{Cu}^{2+}$ while being oxidized in the process, and the complexes formed causing oxidative cleavage of $D_{N A} A^{23,80,66}$. This ability of prodigiosins and tambjamines to act as chemical nucleases can explain some of their biological activities.

Previous research has shown that natural prodigiosins as well as prodigiosin analogues designed with enhanced metal coordinating abilities bind $\mathrm{Cu}^{2+}$ to form complexes with a slightly distorted square planar geometry and $\mathrm{Zn}^{2+}$ to form complexes with tetrahedral geometry ${ }^{25,81}$. Square planar complexes containing aromatic moieties normally bind DNA by intercalation while octahedral and tetrahedral complexes are unsuitable for intercalation, and normally bind externally 82,83

In this chapter we set out to look at several properties; $\mathrm{pKa}, \mathrm{Cu}^{2+}$, and $\mathrm{Zn}^{2+}$ binding ability of $\mathrm{Pg}$ and $\mathrm{Tm}$ analogues, as well as DNA binding and cleavage activity, in order to determine if any of these properties correlate with biological activity. 

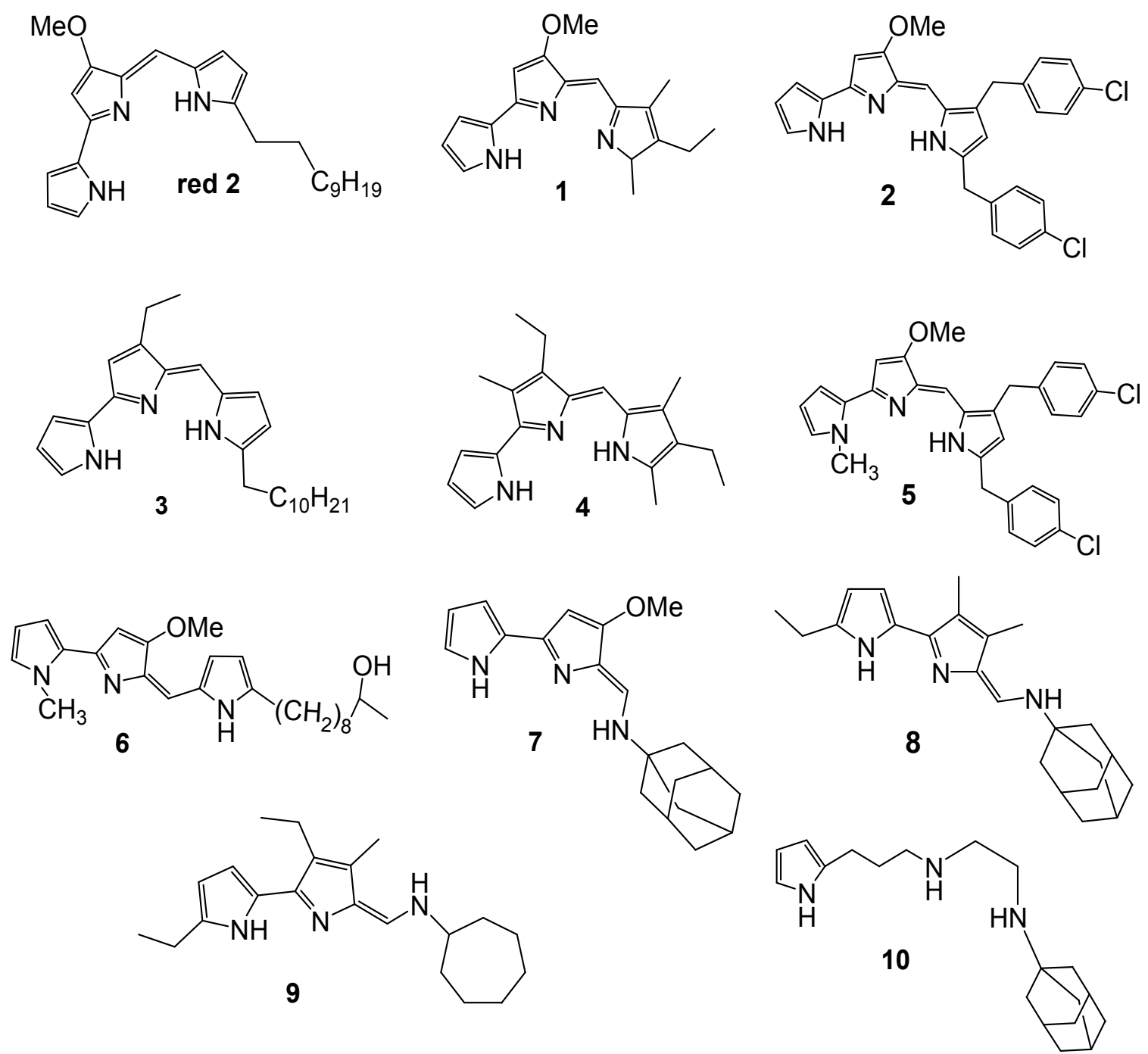

Figure 32. A natural prodigiosin (red 2 ) and prodigisoin and tambjamine analogues (1-10) used in the study. 


\section{Experimental}

\section{Synthesis of Prodiginine and Tambjamine Analogues}<smiles>CCN(/C=C1/N=C(Br)C=C1OC)CC</smiles>

i) $\mathrm{Pd}\left(\mathrm{PPh}_{3}\right)_{4}, \mathrm{~N}-\mathrm{Boc}-2$-pyrroleboronicacid dioxane $/ \mathrm{H}_{2} \mathrm{O}, \mathrm{Na}_{2} \mathrm{CO}_{3}, 100^{\circ} \mathrm{C}, 3 \mathrm{~h}$

ii) $\mathrm{LiOH}, \mathrm{THF}-\mathrm{MeOH}$, rt, $30 \mathrm{~min}, 76 \%$<smiles>[R]c1[nH]c(/C=C2\N=C(c3ccc[nH]3)C=C2OC)c([R])c1[R]</smiles>

$\mathrm{R}_{1}-\mathrm{R}_{2}=$ alkyl(aryl) substituents

Prodiginines

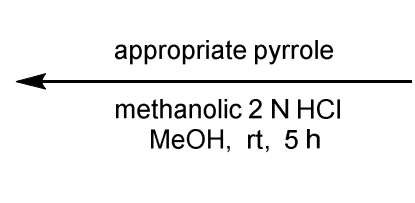
appropriate alkylamine
methanolic $2 \mathrm{~N} \mathrm{HCl}$
$\mathrm{MeOH}$, rt, $5 \mathrm{~h}$

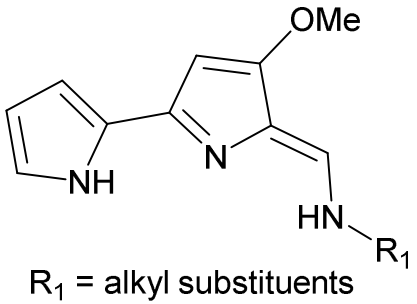

Tambjamines

Scheme 3. Synthesis of prodigiosin and tambjamine analogues. 


\section{Determination of pKa}

The pKa was determined in a wide range buffer series (Carmodys buffers). The buffers were prepared by mixing predetermined volumes of stock buffer solutions (solution A: $0.2 \mathrm{M}$ boric acid; $0.05 \mathrm{M}$ citric acid; solution B: $0.1 \mathrm{M}$ tertiary sodium phospshate) to make solutions with $\mathrm{pH}$ ranging from $2.5-10.5$. The $\mathrm{Pg}$ and $\mathrm{Tm}$ analogues were added to $200 \mu \mathrm{L}$ of buffer to a final concentration of $50 \mu \mathrm{M}$ and spectra were recorded on a Shimadzu 1700 UV-visible spectrophotometer using 1 cm quartz cuvettes.

\section{Mass Spectroscopy Characterization}

Equimolar amounts of $\mathrm{Cu}(\mathrm{OAc})_{2}$ or $\mathrm{Zn}(\mathrm{OAc})_{2}$ were added to solutions of $\mathrm{Pg}$ or $\mathrm{Tm}$ in $90 \%$ methanol. The solutions were allowed to mix for an hour before Mass spectra were recorded on a ThermoElectron LTQ-Orbitrap high resolution mass spectrometer.

\section{DNA}

Calf thymus DNA (CT-DNA) was purchased from Sigma Aldrich chemicals, USA and prepared by dissolving $1 \mathrm{mg}$ in $2 \mathrm{ml}$ of buffer ( $4 \mathrm{mM}$ sodium phosphate, $50 \mathrm{mM}$ $\mathrm{NaCl}, \mathrm{pH}$ 7.8) overnight before use. The purity of CT-DNA was determined by monitoring UV absorbance at $260 \mathrm{~nm}$ and $280 \mathrm{~nm}$. The $A_{260} / A_{280}$ ratio was found to be between $1.8-1.9$ suggesting that the sample was sufficiently free from protein impurities ${ }^{74}$. DNA concentration was determined by UV spectrophotometry using $\varepsilon=6600 \mathrm{Mcm}^{-1}$ at $260 \mathrm{~nm}$. 
Plasmid DNA was prepared from transformation of E. coli Mach1 cells (Life Technologies) with pUC19 DNA. The cells were grown in Luria-Bertani medium for $12-16 \mathrm{~h}$. Plasmid DNA was then purified at $4^{\circ} \mathrm{C}$ using Omega-Biotek E.Z.N.A plasmid purification kit. The purification of plasmid DNA at low temperature ensured isolation of almost $100 \%$ of the plasmids in supercoiled form ${ }^{75}$.

\section{DNA binding activity}

Absorption titration experiments were performed on $\mathrm{Pg}$ and $\mathrm{Tm}$ analogues $(20 \mu \mathrm{M})$ in $4 \mathrm{mM}$ sodium phosphate buffer, $50 \mathrm{mM} \mathrm{NaCl}, \mathrm{pH} 7.8$ while varying concentrations of the CT-DNA $(0-80 \mu \mathrm{M})$. Spectra were recorded on a Shimadzu 1700 UV-visible spectrophotometer using $1 \mathrm{~cm}$ quartz cuvettes.

\section{DNA cleavage}

Concentration dependent cleavage of pUC19 DNA

Agarose gel electrophoresis experiments were performed with pUC19 DNA as previously described. The reaction was quenched by adding $3 \mu \mathrm{L}$ loading buffer (0.03\% bromophenol blue, $0.03 \%$ xylene cyanol FF, $60 \%$ glycerol, 60 mM EDTA). The samples were electrophoresed at $70 \mathrm{~V}$ for $1.5 \mathrm{hr}$ on a $0.8 \%$ agarose gel using tris-acetate-EDTA (TAE) buffer then stained with ethidium bromide. DNA cleavage was visualized using the Typhoon Trio+ variable mode Imager, GE Healthcare, to measure the different isomers of pDNA. 


\section{Results}

\section{Spectrophotometric determination of $p K_{a}$}

The acid-base dissociation constant $\left(\mathrm{p} K_{\mathrm{a}}\right)$ of a drug is a key property influencing lipophilicity, solubility, protein binding and permeability. Knowledge of the $p K_{a}$ helps in understanding the ionic form a molecule will take across a range of $\mathrm{pH}$ values. This is important in physiological systems where ionization state will affect the rate at which the compound is able to diffuse across membranes. In this study, we recorded UV-Vis spectra of the $\mathrm{Pg}$ and $\mathrm{Tm}$ analogues in different $\mathrm{pH}$ buffers $(\mathrm{pH} 2.5-10)$. The absorption spectra of the compounds changes with $\mathrm{pH}$ to reflect the ratio of neutral to ionized species. Data from the first derivative plot was used to determine $\mathrm{pK}$ a values for the $\mathrm{Pg}$ and $\mathrm{Tm}$ analogues.
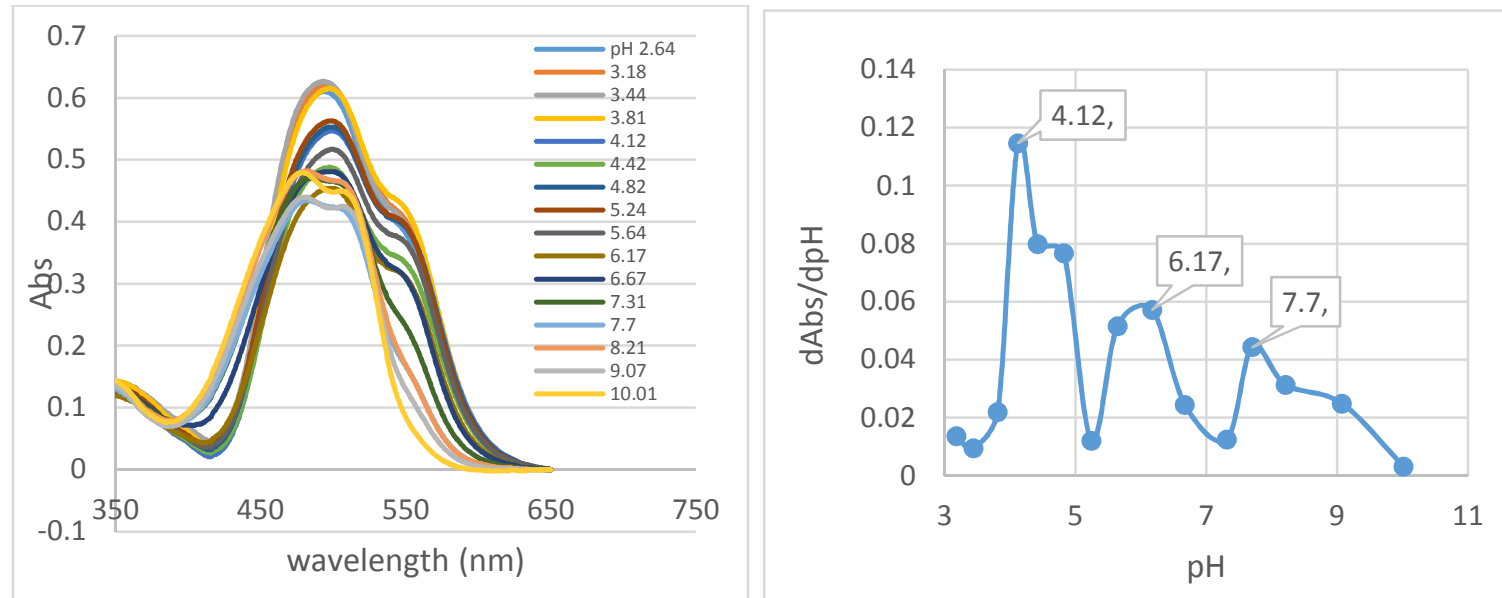

Figure 33. Representative UV-Vis absorbance spectra for prodigiosin analogue as a function of $\mathrm{pH}$ (left panel) and the first derivative plot of change in absorbance as a function of $\mathrm{pH}$ showing the experimental $\mathrm{pK}_{\mathrm{as}}$ (right panel). 
In this plot the largest change in absorbance occurs at the $\mathrm{pH}$ corresponding to a $\mathrm{p} K_{\mathrm{a}}$ and appears as a peak in the first derivative plot. The first derivative plot of the ratio of change in $\mathrm{pH}$ and change in absorbance vs $\mathrm{pH}$ shown in the representative figure 33 .

Table 1. Experimental $p K_{a}$ values of prodigiosin and tambjamine analogues

\begin{tabular}{|l|l|l|l|l|l|l|l|}
\hline & Ring A & Ring B & Ring C & $\mathbf{p K}_{\mathbf{a} 1}$ & $\mathbf{p K}_{\mathbf{a} 2}$ & $\mathbf{p K _ { \mathbf { a } 3 }}$ & $\mathbf{p K}_{\mathbf{a}}$ \\
\hline Red 2 & Pyrrole & $-\mathrm{OMe}$ & $\mathrm{C}_{11} \mathrm{H}_{23}$ & 3.50 & 5.30 & 7.80 & \\
\hline 1 & Pyrrole & $-\mathrm{OMe}$ & $\mathrm{Me}, \mathrm{Et}, \mathrm{Me}$ & 3.45 & 5.48 & 8.06 & \\
\hline 2 & Pyrrole & $-\mathrm{OMe}$ & $\begin{array}{l}\mathrm{Me}-\mathrm{PhCl}, \mathrm{Me}- \\
\mathrm{PhCl}\end{array}$ & 4.0 & 5.70 & 7.80 & \\
\hline 3 & Pyrrole & Et & $\mathrm{C}_{11} \mathrm{H}_{23}$ & 3.40 & 5.20 & 7.70 & \\
\hline 4 & Pyrrole & $\mathrm{Me}, \mathrm{Et}$ & $\mathrm{Me}, \mathrm{Et}, \mathrm{Me}$ & 3.50 & 5.28 & 7.83 & \\
\hline 5 & $\begin{array}{l}\text { N-Me, } \\
\text { pyrrole }\end{array}$ & $-\mathrm{OMe}$ & $\begin{array}{l}\mathrm{Me}-\mathrm{PhCl}, \mathrm{Me}- \\
\mathrm{PhCl}\end{array}$ & 4.20 & 6.0 & 7.90 & \\
\hline 6 & $\begin{array}{l}\text { N-Me, } \\
\text { Pyrrole }\end{array}$ & $-\mathrm{OMe}$ & $\mathrm{C} 9 \mathrm{H}_{20} \mathrm{OH}$ & 3.55 & 4.41 & 5.84 & 7.91 \\
\hline 7 & Pyrrole & $-\mathrm{OMe}$ & adamantyl & 4.0 & 5.70 & 8.30 & \\
\hline 8 & Et-pyrrole & Et, Et & adamantyl & 3.70 & 4.80 & 6.90 & \\
\hline 9 & Et-Pyrrole & $\mathrm{Me}, \mathrm{Et}$ & hexanoyl & 3.80 & 4.40 & 7.50 & \\
\hline 10 & pyrrole & No ring & adamantyl & 3.50 & 5.30 & 7.80 & \\
\hline
\end{tabular}

As seen in table 1, there are very small differences between the pKa values despite the differences in substituents on the rings. Because of this, at physiological $\mathrm{pH}$, the differences would not be significant in terms of how much of the analogue is protonated. 


\section{Mass Spectral Analysis of $\mathrm{Cu}^{2+}$ and $\mathrm{Zn}^{2+}$ complexes in solution}

Synthesis of stable $\mathrm{Cu}^{2+}$ and $\mathrm{Zn}^{2+}$ complexes of the rest of the prodigiosin and tambjamine analogues selected for use in this study proved difficult as the complexes formed were not stable enough to isolate. In light of this observation, formation of $\mathrm{Cu}^{2+}$ and $\mathrm{Zn}^{2+}$ complexes of $\mathrm{Pg}$ and $\mathrm{Tm}$ analogues was monitored by ESI-MS in $90 \%$ methanol (figures 34-39). Complexes of $\mathrm{Cu}^{2+}$ and $\mathrm{Zn}^{2+}$ can easily be recognized in the mass spectrum by their isotope patterns: $\left({ }^{63} \mathrm{Cu}:{ }^{65} \mathrm{Cu} ; 70 ; 30\right)$ and $\left({ }^{64} \mathrm{Zn}:{ }^{66} \mathrm{Zn}:{ }^{67} \mathrm{Zn}:{ }^{68} \mathrm{Zn} ; 49: 28: 4: 19\right)$.

The ESI-MS of red2.Cu showed $\mathrm{m} / \mathrm{z}$ of 453.18 and 455.18 (100:44) consistent with the isotope ratios of $\mathrm{Cu}^{2+}$. The proposed structure of the complex is similar to other previously described $\mathrm{PgCu}$ complexes with an oxidized C-ring. In addition, we observed formation of a copper (II) complex with a methoxylated C-ring under our assay conditions (figure 34 ). 

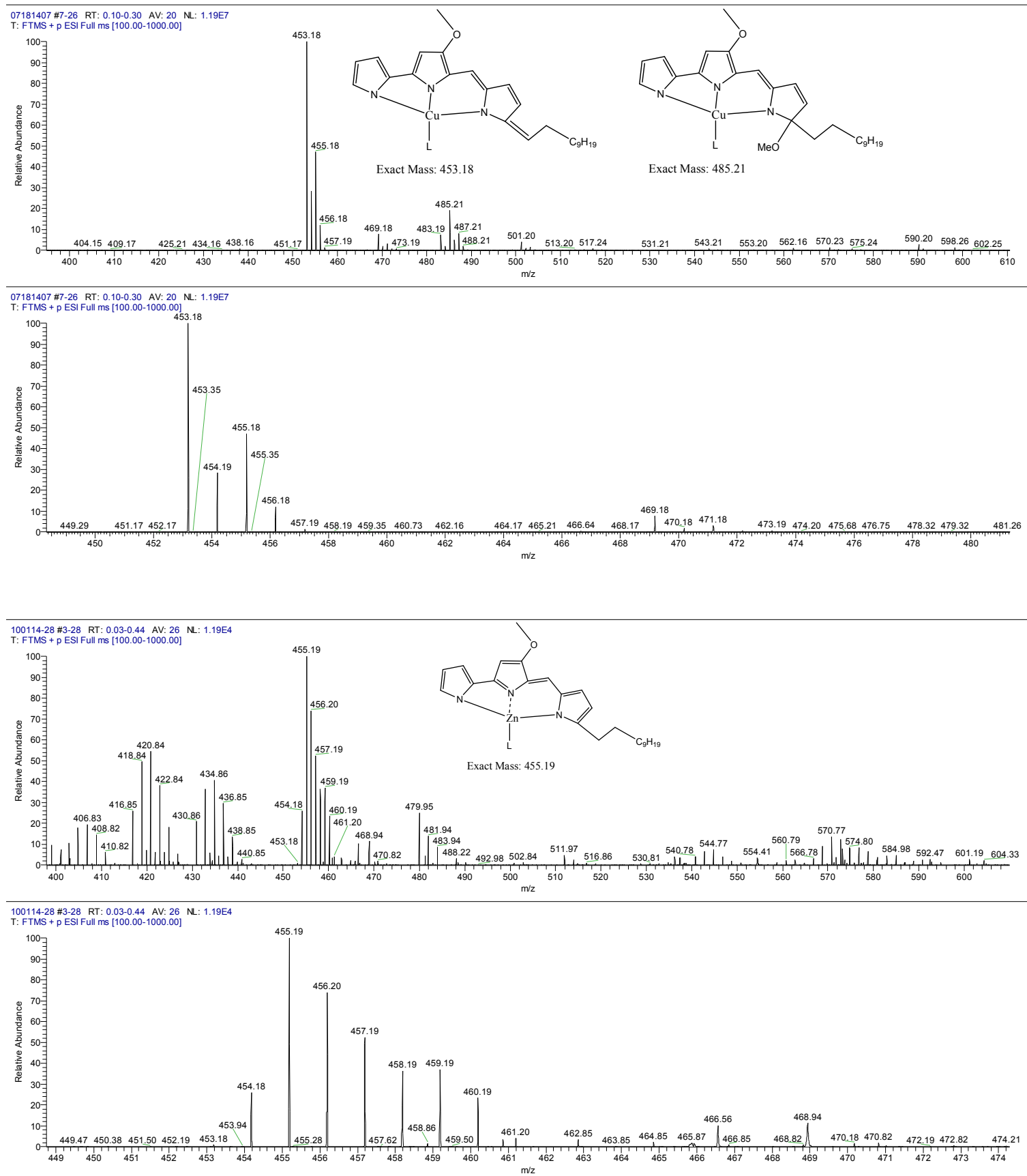

Figure 34. Mass spectra showing formation of Red2 $\cdot \mathbf{C u}$ complex and isotope (top panel) and Red2-Zn complex (bottom panel) in $90 \% \mathrm{MeOH}$. 

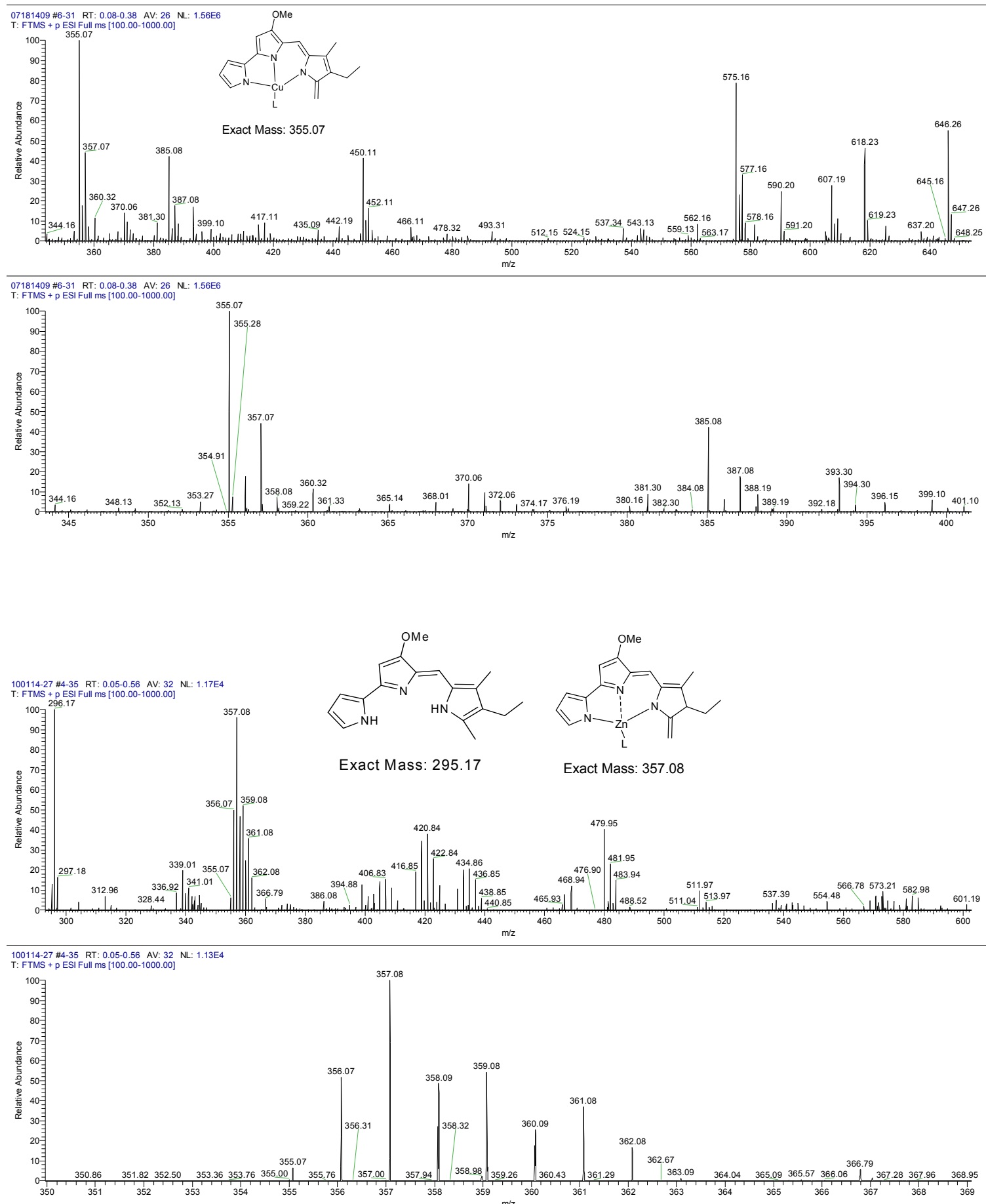

Figure 35. Mass spectra showing in situ formation of 1.Cu complex (top panel) and $\mathbf{1} \cdot \mathrm{Zn}$ complex (bottom panel) in $90 \% \mathrm{MeOH}$. 
In the previous chapter we isolated $\mathbf{1 \cdot C u}$ and confirmed the structure by ESI-MS and NMR. Figure 35 shows the mass spectra obtained from 1 and $\mathrm{CuCl}_{2}$ complex formation in $90 \% \mathrm{MeOH}$. The spectra show peaks with $\mathrm{m} / \mathrm{z}$ values consistent with formation of $\mathrm{Cu}^{2+}$ and $\mathrm{Zn}^{2+}$ complexes in solution. The peaks observed for the $\mathrm{Cu}$ complex (m/z 355.07 and 357.07) and $\mathrm{Zn}$ complex (m/z 357.08, 359.08 and 361.08) are consistent with the isotope pattern expected for $\mathrm{Cu}$ and $\mathrm{Zn}$ respectively.
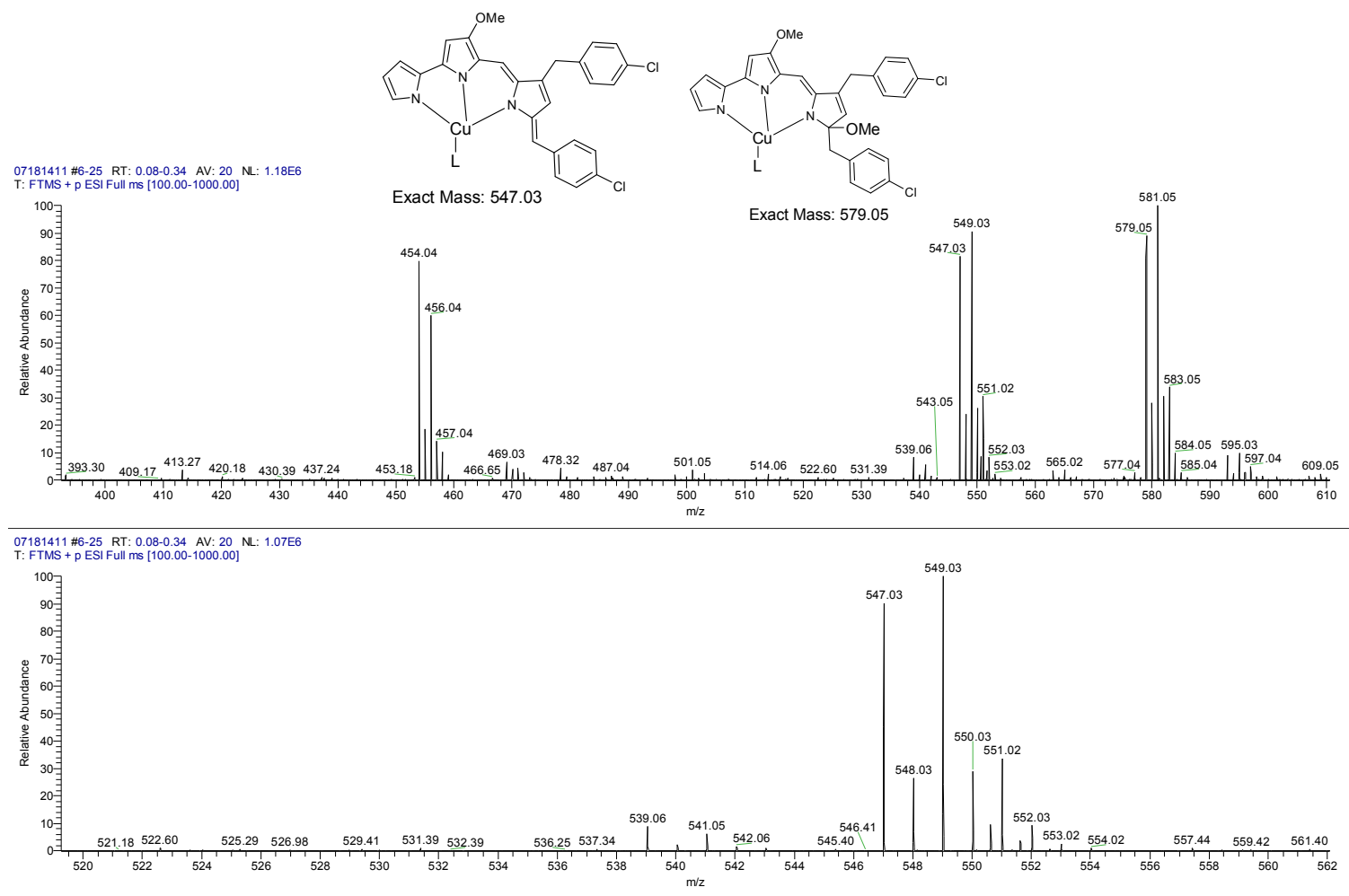

Figure 36. ESI-MS showing formation of $\mathbf{2} \cdot \mathbf{C u}$ complex in $90 \% \mathrm{MeOH}$ 
Analogues 3, 4 and $\mathbf{5}$ showed formation of $\mathrm{Cu}^{2+}$ complexes with either an oxidized or methoxylated C-ring under ESI-MS conditions. However, these 3 analogues do not appear to form a $\mathrm{Zn}^{2+}$ complex under the ESI-MS conditions. Complexes could not be observed for the rest of the analogues and that suggested that either those analogues do not form complexes under our experimental conditions, or that the complexes are not able to be detected by ESI-MS.
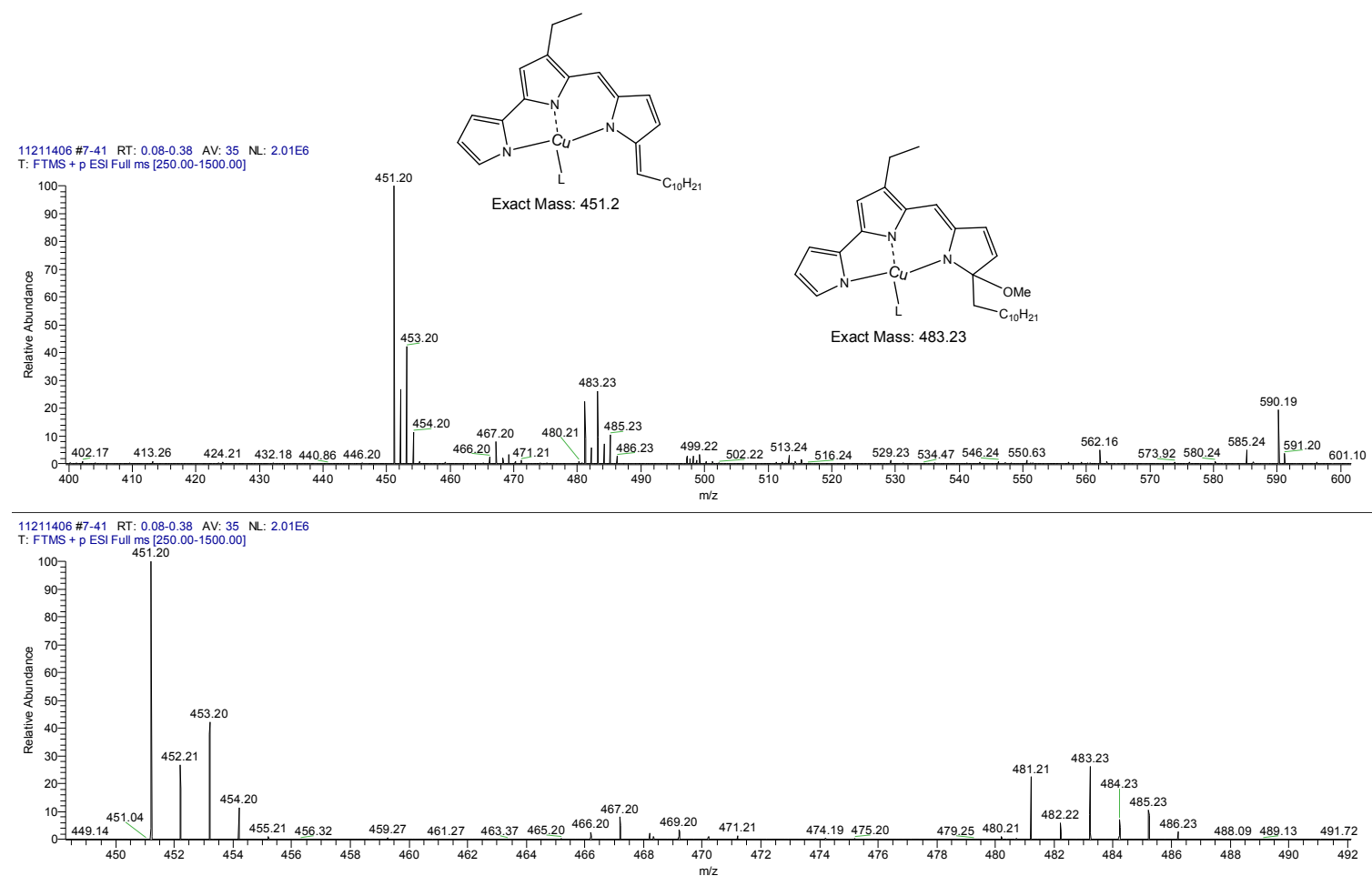

Figure 37. ESI-MS showing formation of 3. Cu complex in $90 \% \mathrm{MeOH}$. 

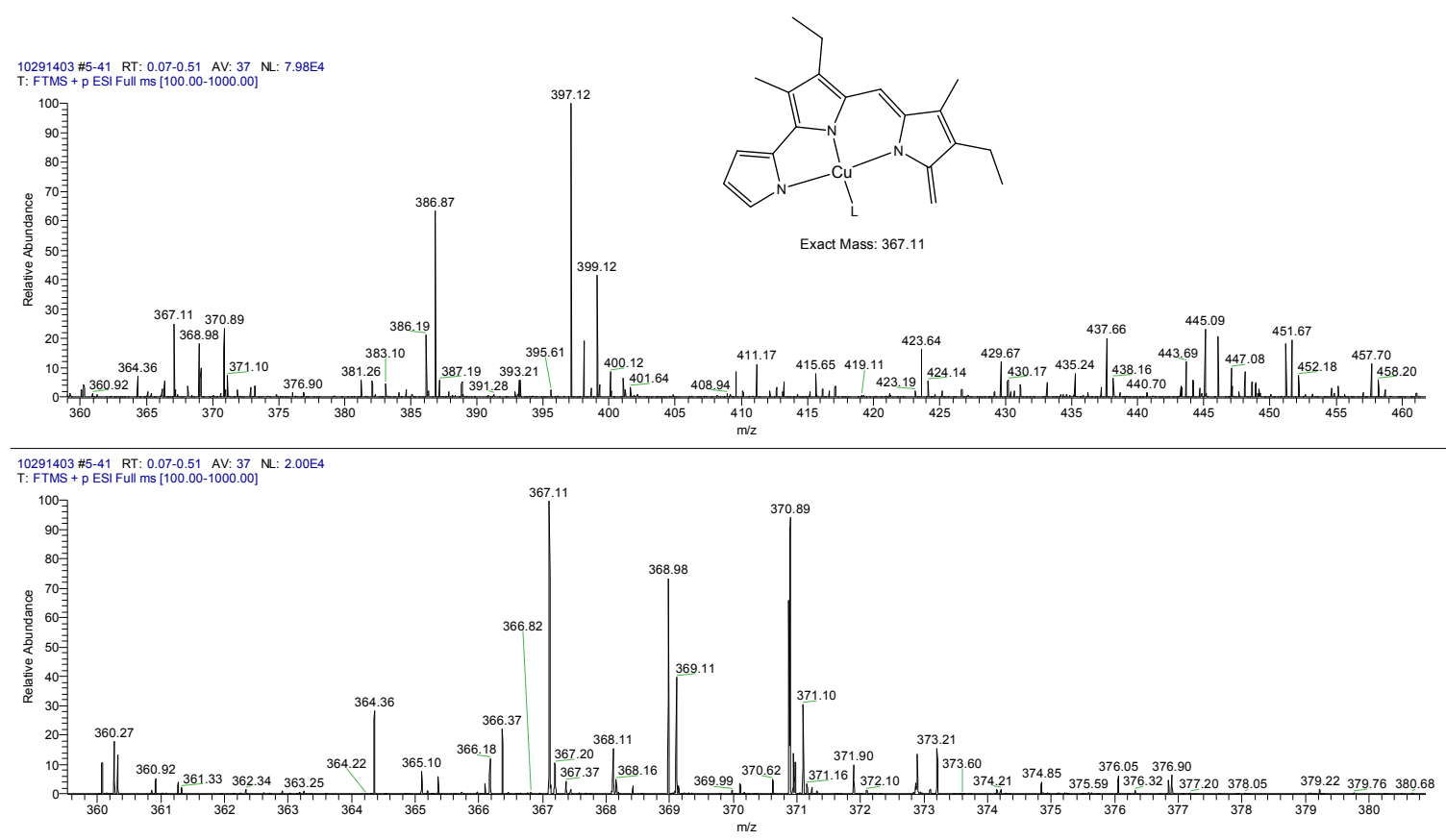

Figure 38. ESI-MS showing formation of $4 \cdot \mathrm{Cu}$ complex in $90 \% \mathrm{MeOH}$, no complex formation with $\mathrm{Zn}^{2+}$ under our experimental conditions.
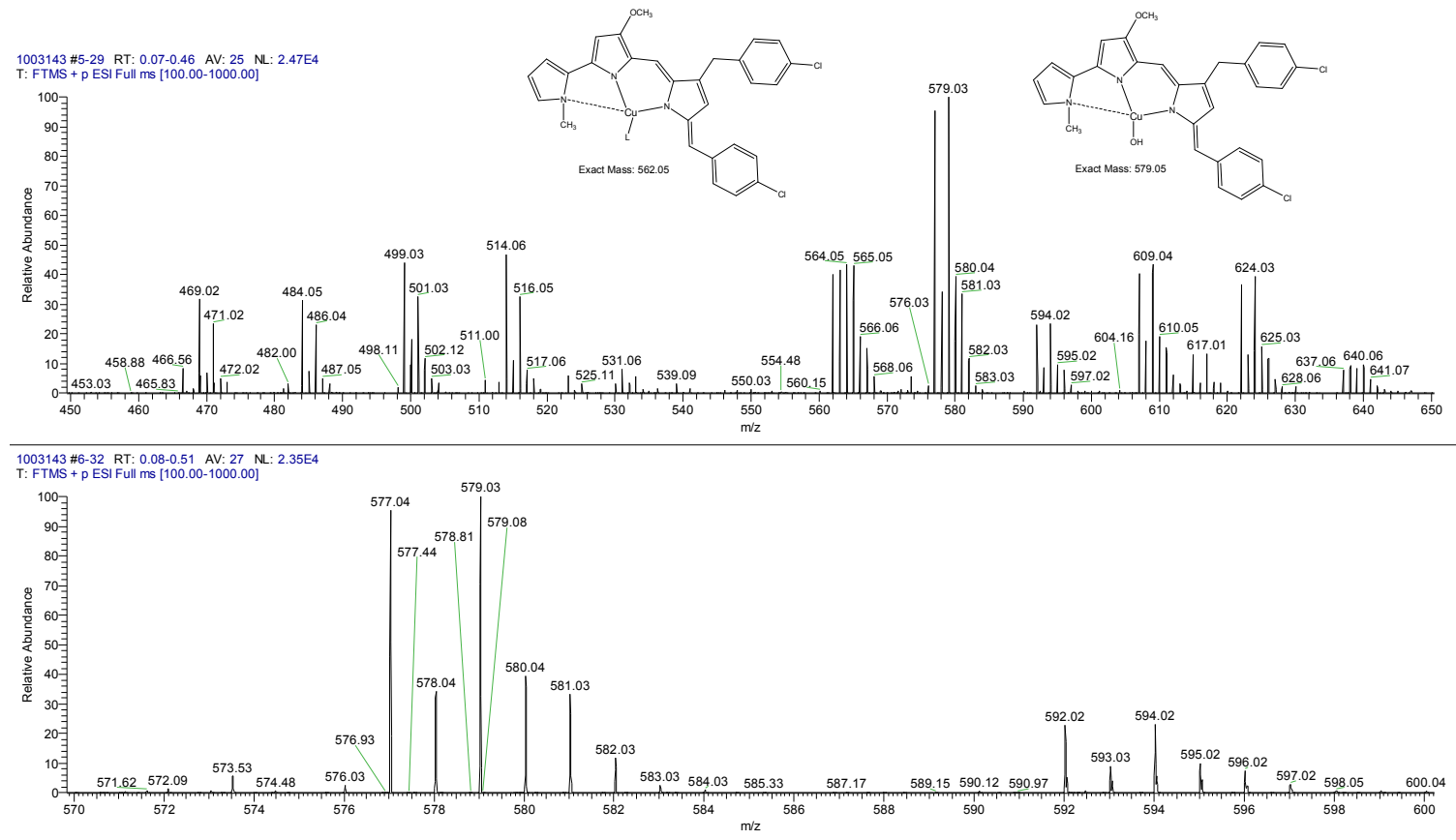

Figure 39. ESI-MS showing formation of $\mathbf{5} \cdot \mathrm{Cu}$ complex in $90 \% \mathrm{MeOH}$, no complex formation with $\mathrm{Zn}^{2+}$ under our experimental conditions. 


\section{DNA Binding activity of Pg and Tm analogues}

In order to determine the nature of interactions between DNA and the Pg and Tm analogues, the analogues were incubated with CT-DNA in the presence and absence of metal ions. The metal ions $\left(\mathrm{Cu}^{2+}\right.$ and $\left.\mathrm{Zn}^{2+}\right)$ were included in order to assess if there was a difference in binding mode of the free analogue compared with metal complex, and also to compare binding modes of possible $\mathrm{Cu}^{2+} \mathrm{vs} \mathrm{Zn}^{2+}$ complexes that would be formed under the assay conditions. The binding was observed through changes in absorbance spectra. Red2 and compounds 1, 2, 3, 5 and 6 are colored red but appear orange in the buffer at $\mathrm{pH} 7.8$. These exhibited absorption bands in the visible region of the spectrum $(450-650 \mathrm{~nm})$. The rest of the compounds were orange/yellow in methanol, but have no visible color in the $\mathrm{pH} 7.8$ buffer and absorbed in the UV region (300-450 nm), except for compound 10 that had no absorption peak in the UV-Vis spectrum at this $\mathrm{pH}$.

Figure 40 (top panel) shows the increase in absorption of red2 in the presence of increasing CT-DNA $(0-80 \mu \mathrm{M})$ concentration. The hyperchromic effect observed was accompanied by a $13 \mathrm{~nm}$ shift in $\lambda_{\max }$ from $575 \mathrm{~nm}$ of free red2 to $562 \mathrm{~nm}$ for red2 in the presence of DNA. When $\mathrm{Cu}^{2+}$ is added to red2 in the presence of varying concentrations of CT-DNA the same hyperchromic effect is observed at the absorption band at $534 \mathrm{~nm}$. These spectroscopic changes suggest an interaction between the ligand and the DNA that is not intercalation. These observations contrast those made for $\mathbf{1} \cdot \mathbf{C u}$ which intercalates into DNA, and suggests that, just like the free analogues, $\mathrm{Cu}^{2+}$ complexes of prodigiosins will bind 


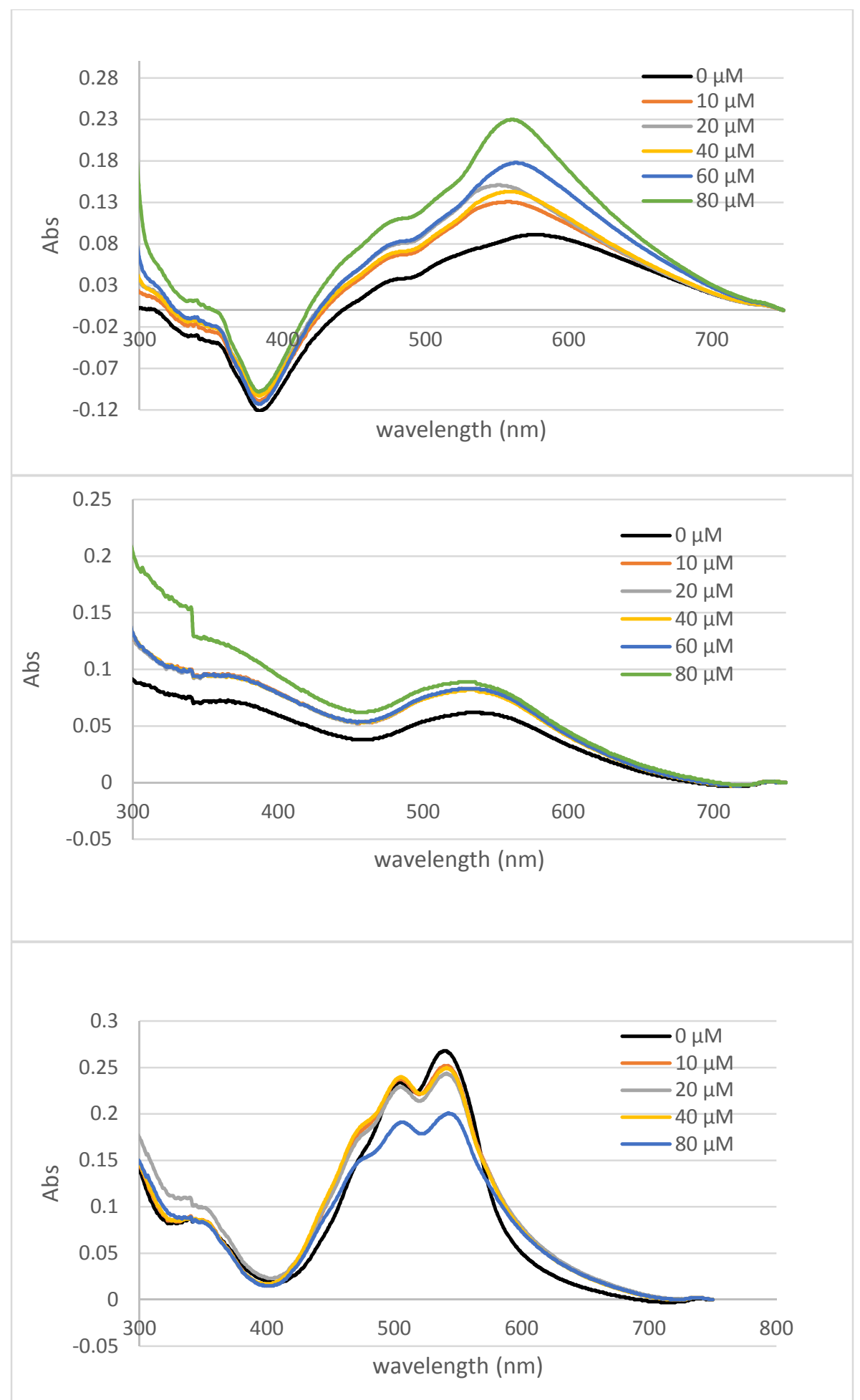

Figure 40. Spectral changes observed in the interaction of red2 with varying concentrations of CT-DNA in the absence (top panel) and presence of $\mathrm{Cu}^{2+}$ (middle panel) and $\mathrm{Zn}^{2+}$ (bottom panel). 
DNA by mixed modes ${ }^{80}$. Our ESI-MS data suggests that a red2 $\cdot \mathrm{Cu}$ complex can form in situ which means the pyrrole ring nitrogens in the red2.Cu complex are not available for hydrogen bonding. Since we do not observe spectral changes expected for intercalation, this leaves electrostatic forces or groove binding as possible modes of interactions between red2 $\cdot \mathrm{Cu}$ complex and CT-DNA.

In contrast, the presence of $\mathrm{Zn}^{2+}$ resulted in a $25 \%$ hypochromic shift accompanied by a $3 \mathrm{~nm}$ red shift in the absorbance of red2 with varying concentrations of CTDNA. This observation suggests that the $\mathrm{Zn}^{2+}$ complex interacts with DNA by a stacking interaction such as intercalative binding mode. Bathochromic (red) shift and hypochromic effect are characteristic of intercalation ${ }^{84}$.

Analogue 2 interacted with CT-DNA similar to what was observed with red2 with hyperchromic effect observed in the absence and presence of $\mathrm{Cu}^{2+}$ and hypochromic effect in the presence of $\mathrm{Zn}^{2+}$ (figure 41).

With the analogues $\mathbf{3}, \mathbf{5}$ and $\mathbf{6}$, hyperchromic effect accompanied by blue shift was observed in all the spectra of varying concentrations of CT-DNA with and without $\mathrm{Cu}^{2+}$ or $\mathrm{Zn}^{2+}$. This observation is consistent with ESI-MS data where no $\mathrm{Zn}^{2+}$ complex was observed so the DNA binding mode in the presence of $\mathrm{Zn}^{2+}$ would be expected to be similar to free 3 . The hyperchromism observed in the presence of $\mathrm{Cu}^{2+}$ suggests that $\mathrm{Cu}^{2+}$ complexes formed in situ are not intercalating into DNA. Hyperchromism and blue shift suggest binding through external contact ${ }^{85}$. 


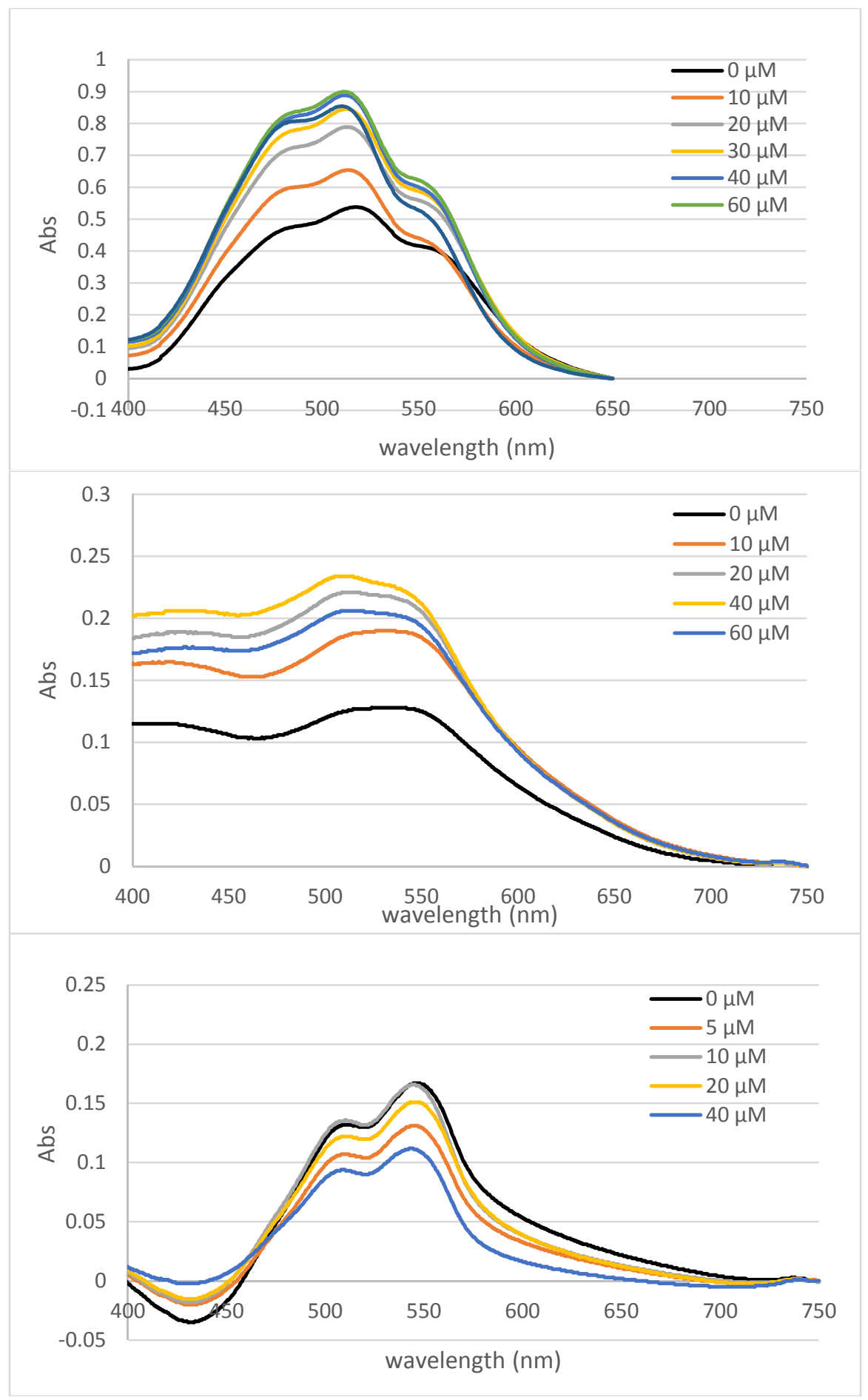

Figure 41. Spectral changes observed in the interaction of 2 with varying concentrations of CT-DNA in the absence (top panel) and presence of $\mathrm{Cu}^{2+}$ (middle panel) and $\mathrm{Zn}^{2+}$ (bottom panel). 


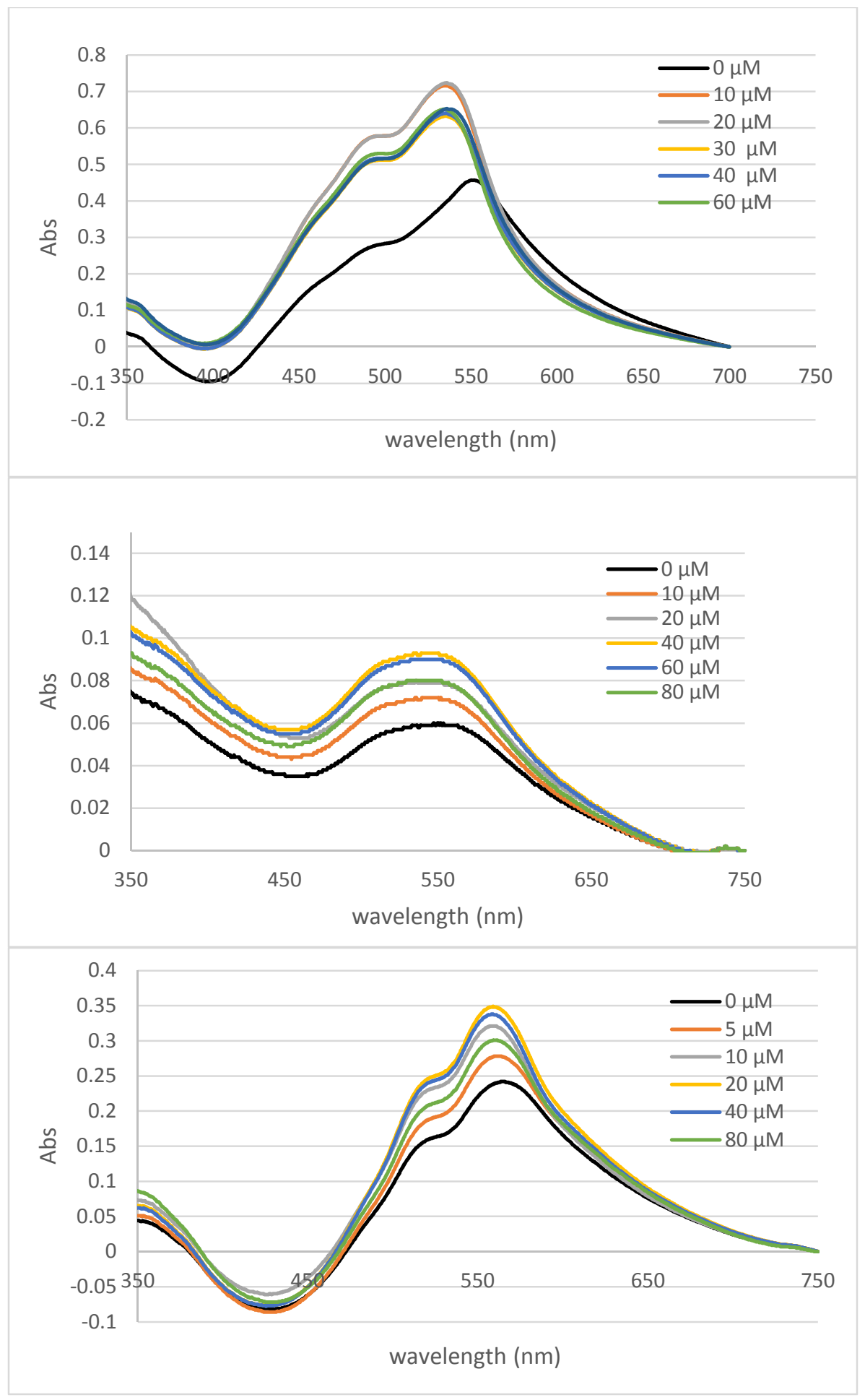

Figure 42. Interaction of $\mathbf{3}$ with CT-DNA results in an increase in absorption of the prodigiosin analogue in the absence (top panel) and presence of $\mathrm{Cu}^{2+}$ (middle panel) and $\mathrm{Zn}^{2+}$ (bottom panel). 


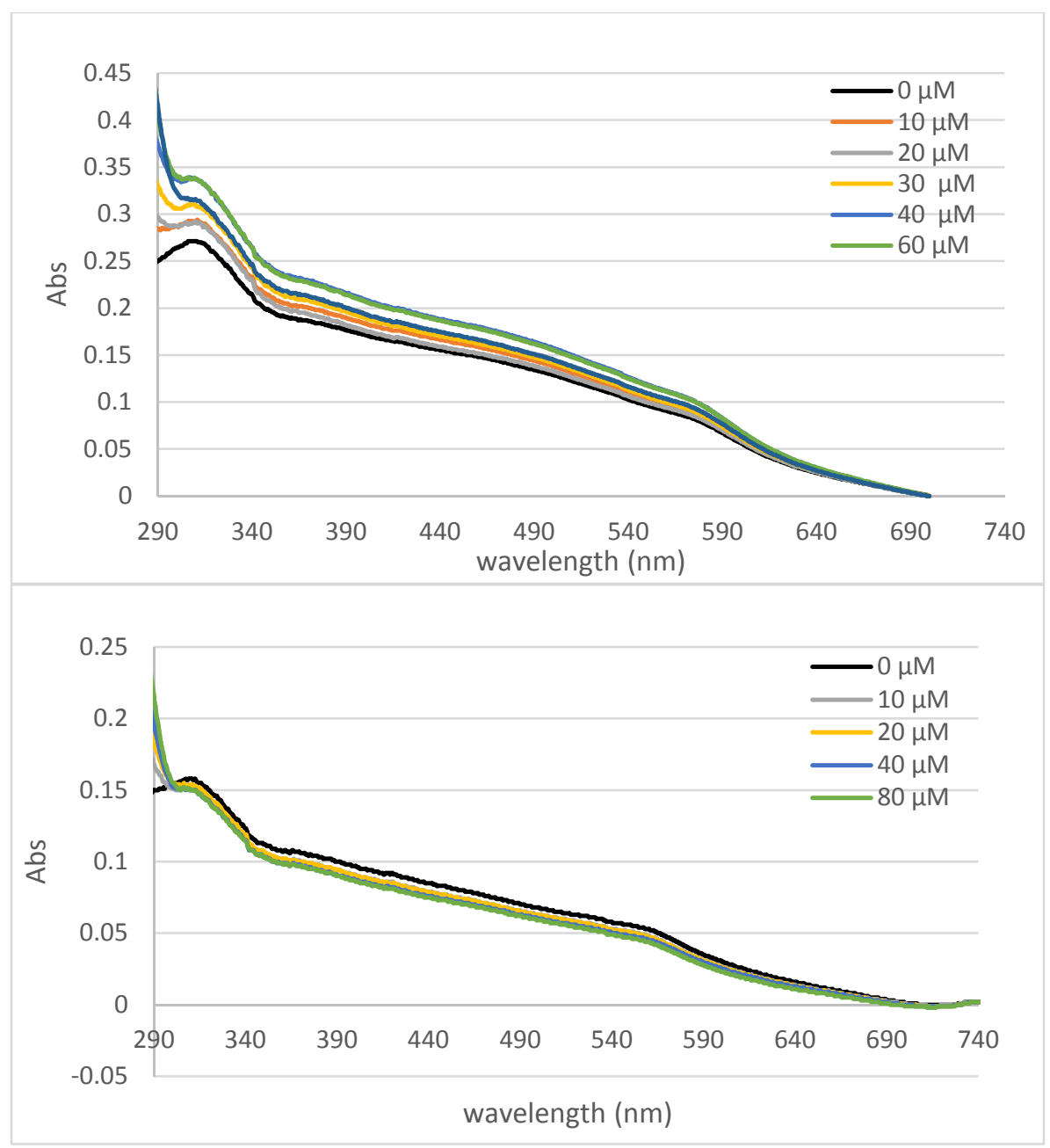

Figure 43. Interaction of $\mathbf{4}$ with CT-DNA results in a slight increase in absorption of the prodigiosin analogue in the absence (top panel) and no change in the presence of $\mathrm{Zn}^{2+}$ (bottom panel).

Analogues 4, 5 and 6 also showed hyperchromic effect on addition of DNA in the absence of the metal ions. The interaction of 4 with DNA in the presence of $\mathrm{Cu}^{2+}$ could not be followed using UV-Vis as the UV-Vis signal was lost on addition of $\mathrm{Cu}^{2+}$. ESI-MS data suggests that 4 forms a complex with $\mathrm{Cu}$ so the lack of a UVvis signal suggests that the complex formed does not have a distinct UV-vis peak. 


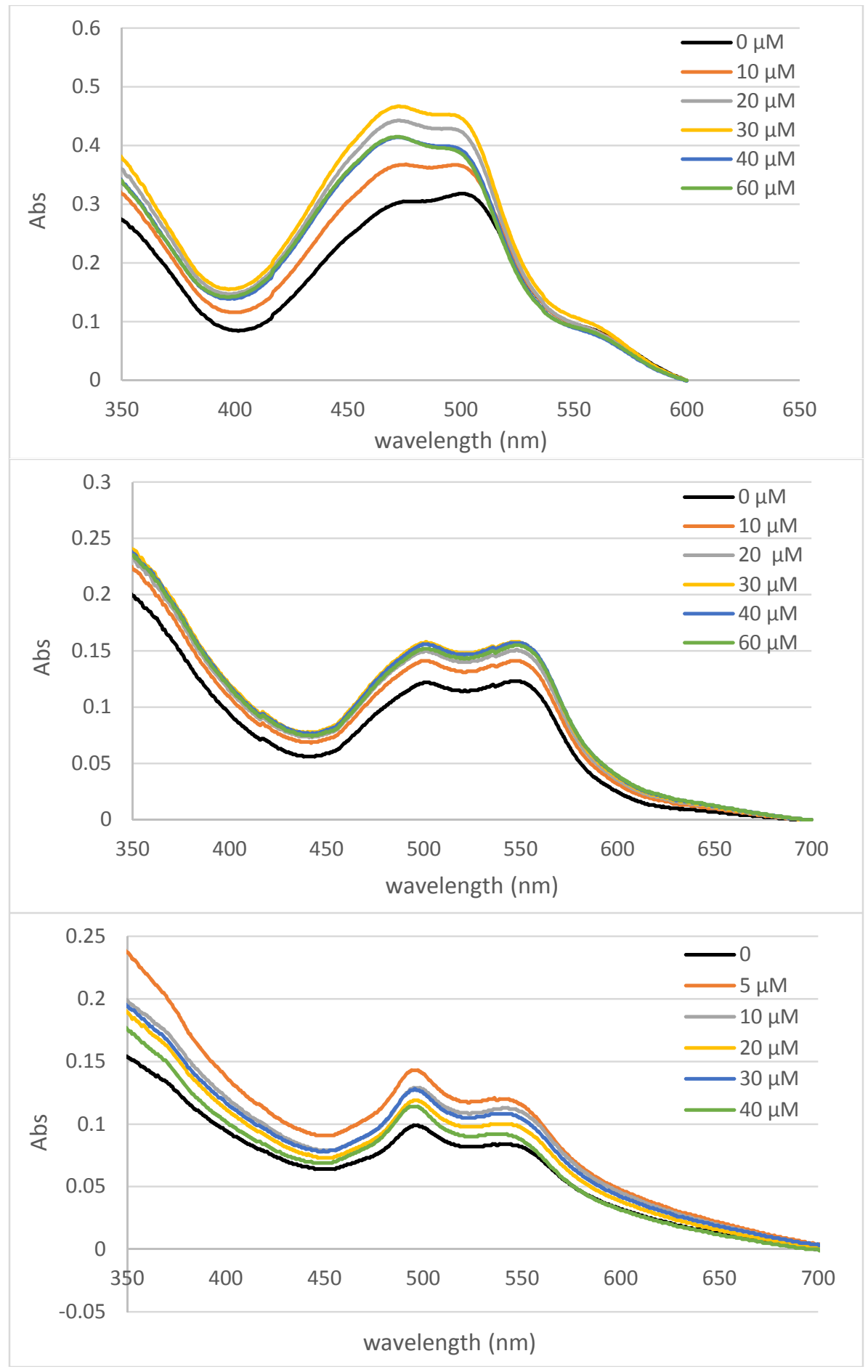

Figure 44. Interaction of 5 with CT-DNA results in an increase in absorption of the prodigiosin analogue in the absence (top panel) and presence of $\mathrm{Cu}^{2+}$ (middle panel) and $\mathrm{Zn}^{2+}$ (bottom panel). 


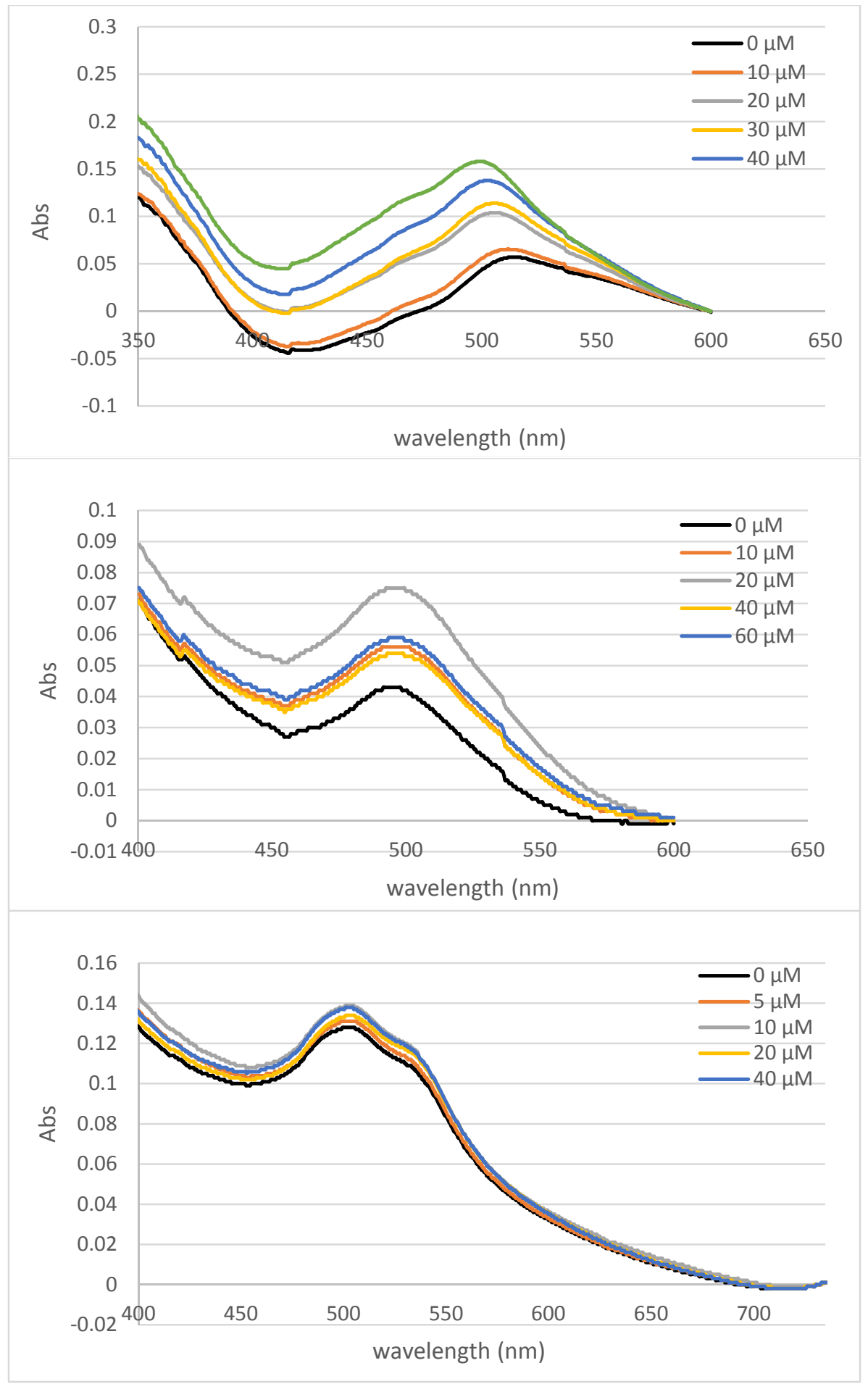

Figure 45. Interaction of 6 with CT-DNA results in an increase in absorption of the prodigiosin analogue in the absence (top panel) and presence of $\mathrm{Cu}^{2+}$ (middle panel) and to a lesser extent $\mathrm{Zn}^{2+}$ (bottom panel). 
Analogue 7 does not appear to interact with DNA based on the UV-Vis experiment. Even in the presence of $\mathrm{Cu}^{2+}$ there was no change in the UV-vis spectra of $\mathbf{7}$ in varying concentrations of CT-DNA (figure 46). However, in the presence of $\mathrm{Zn}^{2+} \mathrm{a}$ clear hyperchromic effect is observed suggesting that $\mathrm{Zn}^{2+}$ probably forms a complex that intercalates into DNA although this complex could not be observed in our ESI-MS experiments.

We did not observe complex formation with analogue 8 under ESI-MS conditions. This situation is similar to that seen with compound 7. However, unlike 7, 8 does interact with DNA as seen by observed hypochromic shift in the UV-Vis absorbance spectra (figure 47). With addition of $\mathrm{Cu}^{2+}$ however, 8 loses the ability to interact with CT-DNA and addition of $\mathrm{Zn}^{2+}$ resulted in a hyperchromic shift in the absorbance.

Analogue 9 interacts with CT-DNA resulting in an increase in absorbance of the analogue as concentration of DNA is increased both in the presence and absence of $\mathrm{Zn}^{2+}$ (figure 48). In the presence of $\mathrm{Cu}^{2+} 9$ loses its absorption peak, and there is no distinct peak to observe except for a shoulder around $370 \mathrm{~nm}$. However, there were no changes in absorbance observed in this shoulder. 


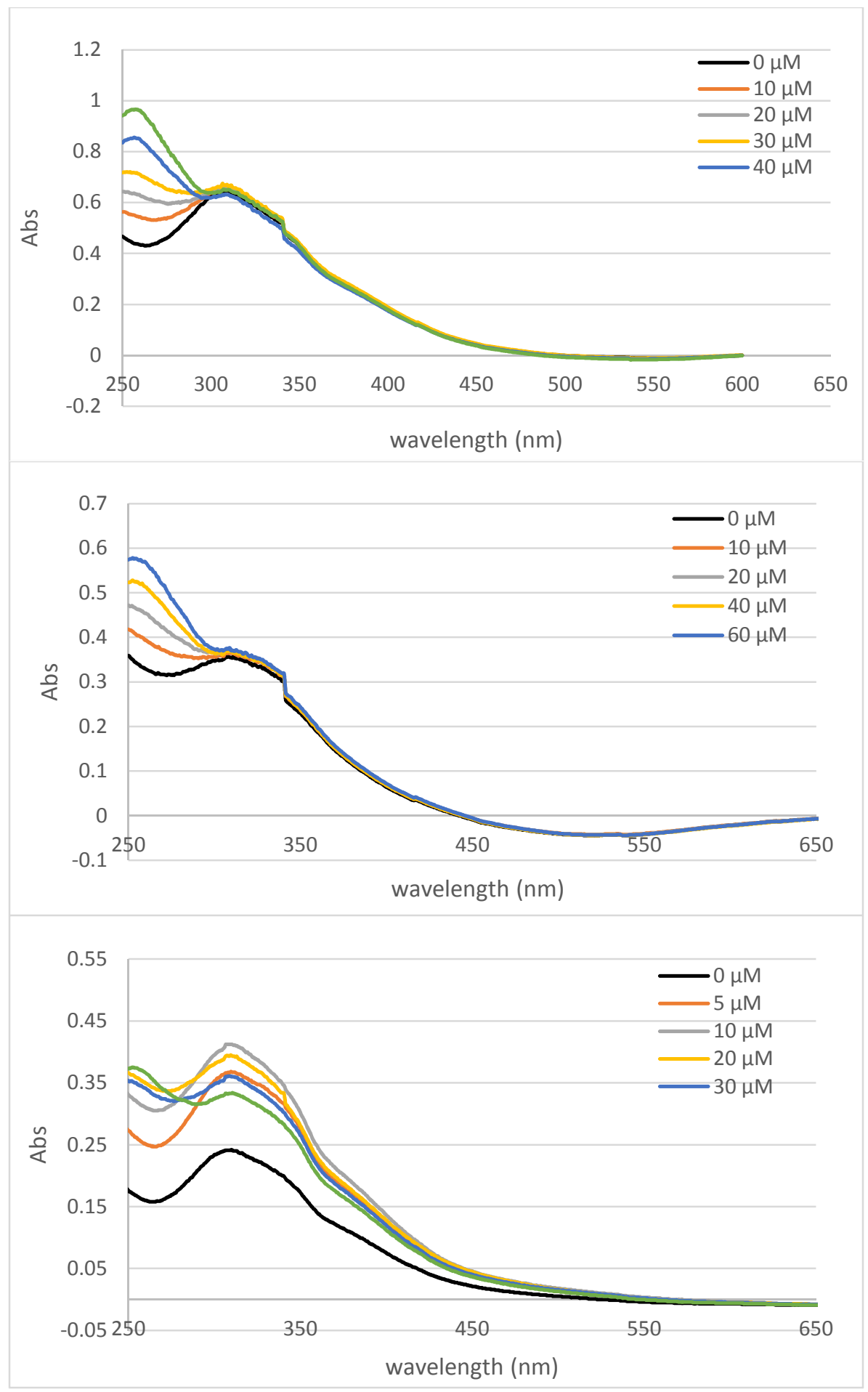

Figure 46. Interaction of 7 with CT-DNA does not change the absorption of the prodigiosin analogue $(300 \mathrm{~nm})$ in the absence (top panel) and presence of $\mathrm{Cu}^{2+}$ (middle panel). An increase in absorption is observed in the presence of $\mathrm{Zn}^{2+}$ (bottom panel). 


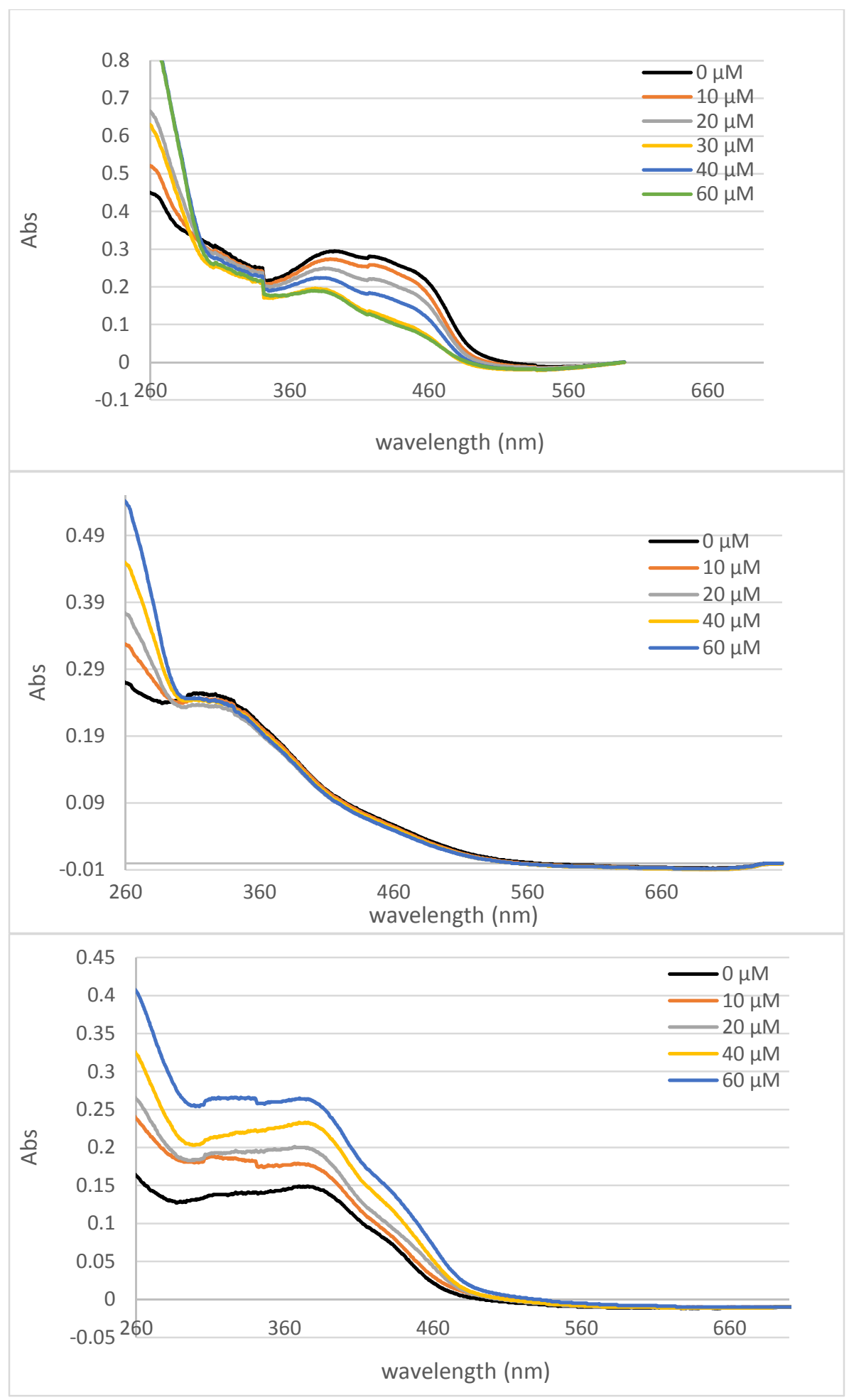

Figure 47. Interaction of 8 with CT-DNA results in an increase in absorption of the prodigiosin analogue in the absence (top panel) and presence of $\mathrm{Cu}^{2+}$ (middle panel) and $\mathrm{Zn}^{2+}$ (bottom panel). 


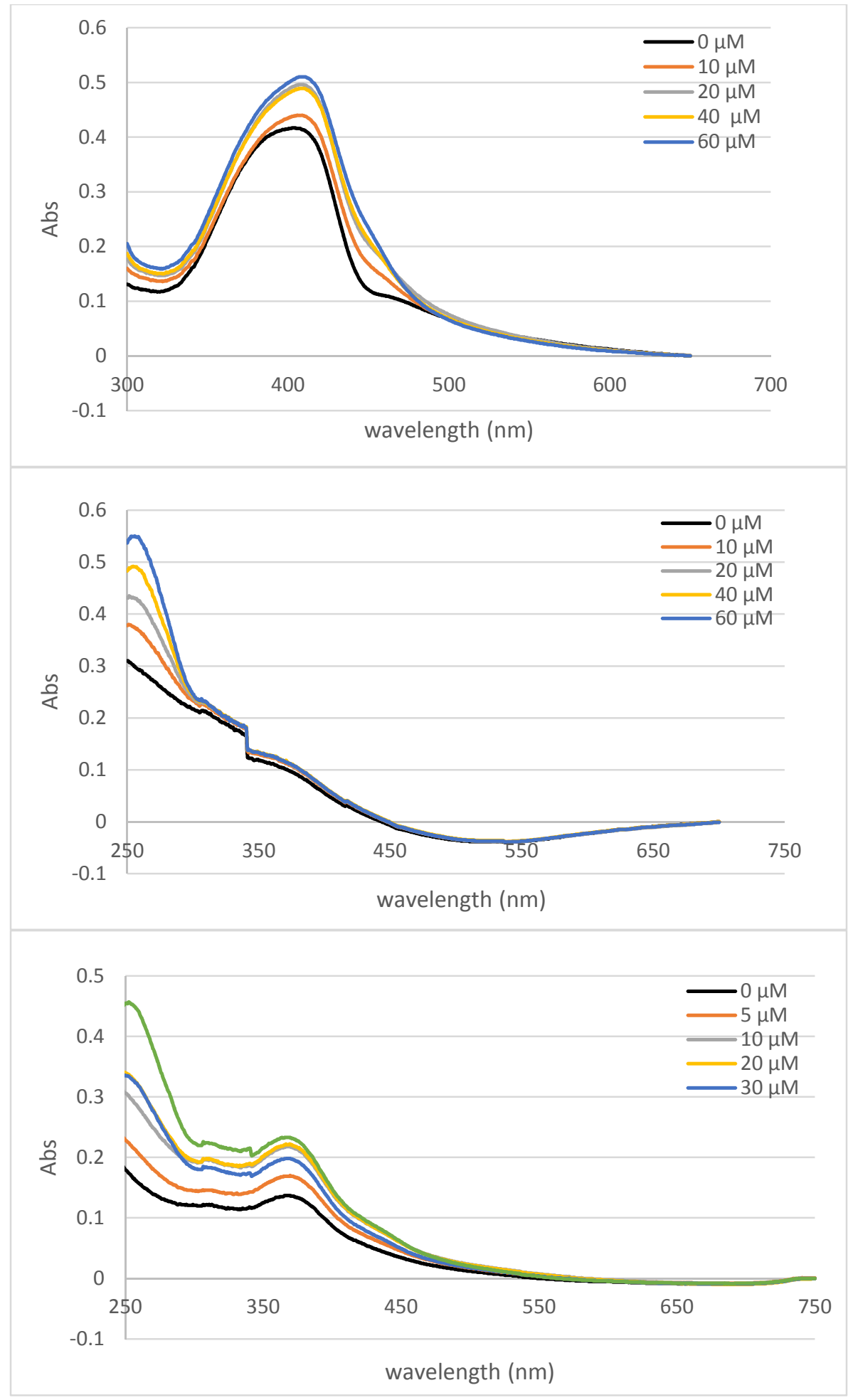

Figure 48. Interaction of 9 with CT-DNA results in an increase in absorption of the prodigiosin analogue in the absence (top panel) and presence of $\mathrm{Zn}^{2+}$ (bottom panel) and no change in absorbance with $\mathrm{Cu}^{2+}$ (middle panel). 
Interaction of $\mathbf{1 0}$ with CT-DNA could not be determined by this method because the analogue did not have a UV-Vis signal. A summary of the observations from these experiments is shown in table 2 :

Table 2: Summary of observed UV-Vis spectral changes of prodigiosin and tambjamine analogues in the presence of $40 \mu \mathrm{M}$ CT-DNA.

\begin{tabular}{|c|c|c|c|}
\hline & Free analogue & $\mathrm{Cu}^{2+}$ & $\mathrm{Zn}^{2+}$ \\
\hline red2 & $\begin{array}{c}13 \mathrm{~nm} \text { blue shift } \\
60 \% \text { hyperchromicity }\end{array}$ & $\begin{array}{c}\text { no } \lambda_{\max } \text { shift } \\
19 \% \text { hyperchromicity }\end{array}$ & $\begin{array}{c}3 \mathrm{~nm} \text { red shift } \\
25 \% \text { hypochromicity }\end{array}$ \\
\hline 1 & $\begin{array}{c}\text { no } \lambda_{\max } \text { shift } \\
28 \% \text { hyperchromicity }\end{array}$ & $\begin{array}{c}\text { no } \lambda_{\max } \text { shift } \\
23 \% \text { hypochromicity }\end{array}$ & $\begin{array}{c}\text { no } \lambda_{\max } \text { shift } \\
9 \% \text { hyperchromicity }\end{array}$ \\
\hline 2 & $\begin{array}{c}6 \mathrm{~nm} \text { blue shift } \\
50 \% \text { hyperchromicity }\end{array}$ & $\begin{array}{c}\text { no } \lambda_{\max } \text { shift } \\
12 \% \text { hyperchromicity }\end{array}$ & $\begin{array}{c}\text { no } \lambda_{\max } \text { shift } \\
47 \% \text { hypochromicity }\end{array}$ \\
\hline 3 & $\begin{array}{l}24 \mathrm{~nm} \text { blue shift } \\
30 \% \text { hyperchromicity }\end{array}$ & $\begin{array}{c}\text { no } \lambda_{\max } \text { shift } \\
33 \% \text { hyperchromicity }\end{array}$ & $\begin{array}{l}7 \mathrm{~nm} \text { blue shift } \\
28 \% \text { hyperchromicity }\end{array}$ \\
\hline 4 & $\begin{array}{c}\text { no } \lambda_{\max } \text { shift } \\
19 \% \text { hyperchromicity }\end{array}$ & no $\lambda_{\max }$ shift & no $\lambda_{\max }$ shift \\
\hline 5 & $\begin{array}{c}28 \mathrm{~nm} \text { blue shift } \\
32 \% \text { hyperchromicity }\end{array}$ & $\begin{array}{c}\text { no } \lambda_{\max } \text { shift } \\
22 \% \text { hyperchromicity }\end{array}$ & $\begin{array}{c}\text { no } \lambda_{\max } \text { shift } \\
17 \% \text { hyperchromicity }\end{array}$ \\
\hline 6 & $\begin{array}{c}11 \mathrm{~nm} \text { blue shift } \\
59 \% \text { hyperchromicity }\end{array}$ & $\begin{array}{c}\text { no } \lambda_{\max } \text { shift } \\
20 \% \text { hyperchromicity }\end{array}$ & $\begin{array}{c}\text { no } \lambda_{\max } \text { shift } \\
8 \% \text { hyperchromicity }\end{array}$ \\
\hline 7 & $\begin{array}{c}\text { no } \lambda_{\max } \text { shift } \\
-\end{array}$ & no $\lambda_{\max }$ shift & $\begin{array}{c}\text { no } \lambda_{\max } \text { shift } \\
28 \% \text { hyperchromicity }\end{array}$ \\
\hline 8 & $\begin{array}{l}\text { 14nm blue shift } \\
35 \% \text { hypochromicity }\end{array}$ & $\begin{array}{c}\text { no } \lambda_{\max } \text { shift } \\
-\end{array}$ & $\begin{array}{c}\text { no } \lambda_{\max } \text { shift } \\
43 \% \text { hyperchromicity }\end{array}$ \\
\hline 9 & $\begin{array}{c}6 \mathrm{~nm} \text { red shift } \\
15 \% \text { hyperchromicity }\end{array}$ & no $\lambda_{\max }$ shift & $\begin{array}{c}\text { no } \lambda_{\max } \text { shift } \\
31 \% \text { hyperchromicity }\end{array}$ \\
\hline 10 & \multicolumn{3}{|c|}{ No UV-Vis signal } \\
\hline
\end{tabular}

Percent hyper/hypochromicity $(\% \mathrm{H})$ was calculated using the equation;

$$
\% H=\frac{\varepsilon f-\varepsilon b}{\varepsilon f} * 100 \%
$$

Where $\varepsilon_{f}$ and $\varepsilon_{b}$ are the extinction coefficient of free and fully bound ligand. 
As seen in table 2, the Pg and $\mathrm{Tm}$ analogues interact with DNA mainly through non intercalative binding modes, with the exception of red $\cdot \mathbf{Z n}, \mathbf{1} \cdot \mathbf{C u}, \mathbf{1} \cdot \mathbf{Z n}$ and compounds 8 and 9 where hypochromism was observed which suggests a stacking interaction. There was no trend observed that relates the mode of DNA binding to the structure of the analogues.

\section{DNA Cleavage}

\section{Concentration Dependent DNA Cleavage}

The DNA cleavage activity of the $\mathrm{Pg}$ and $\mathrm{Tm}$ analogues in the presence of $\mathrm{Cu}^{2+}$ and $\mathrm{Zn}^{2+}$ was studied using supercoiled pUC19 plasmid DNA as a substrate under physiological conditions $\left(\mathrm{pH} 7.4,37^{\circ} \mathrm{C}\right)$ for $1 \mathrm{hr}$. In the presence of a DNA nuclease if only one strand is cleaved, the supercoiled form will relax to produce a nicked circular form, and a linear form will be produced if both strands are cleaved. These three plasmid DNA conformations were distinguishable when subjected to agarose gel electrophoresis.

Figure 49 shows a representative gel from the concentration dependent cleavage of DNA by the analogues in the presence of $\mathrm{Cu}^{2+}$. 


$\begin{array}{lccccccc}\mathrm{pUC19} & + & + & + & + & + & + & + \\ 1 & 50 \mathrm{nM} & 100 \mathrm{nM} & 300 \mathrm{nM} & 500 \mathrm{nM} & 1 \mathrm{uM} & 2.5 & 5 \mu \mathrm{M} \\ \mathrm{Cu}^{2+} & + & + & + & + & + & + & + \\ \mathrm{H}_{2} \mathrm{O}_{2} & + & + & + & + & + & + & +\end{array}$

Form II

Form III

Form I

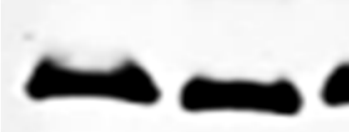

Figure 49. Gel shift analysis showing cleavage of pUC19 DNA in the presence of 1 and added equimolar $\mathrm{Cu}^{2+}$ and $25 \mu \mathrm{M} \mathrm{H}_{2} \mathrm{O}_{2}$ at $37^{\circ} \mathrm{C}$.

All the compounds in the presence of $\mathrm{Cu}^{2+}$ and $\mathrm{H}_{2} \mathrm{O}_{2}$ showed significant DNA cleavage activity in a concentration dependent manner. The gel shift analysis shown in figure 49 shows noticeable linear DNA from about $500 \mathrm{nM}$ of 1 which increases as concentration of 1 increases up to $5 \mu \mathrm{M}$. At the same time the amount of form I DNA on the gel decreases as concentration of 1 increases confirming conversion of form I to form III.

The linear DNA on the gels was quantified and is shown in figures 50-53. In the presence of $\mathrm{Cu}^{2+}$ and $\mathrm{H}_{2} \mathrm{O}_{2}$ there was a concentration-dependent increase in cleavage of supercoiled DNA to the linear form with increase in concentration of test compounds. 


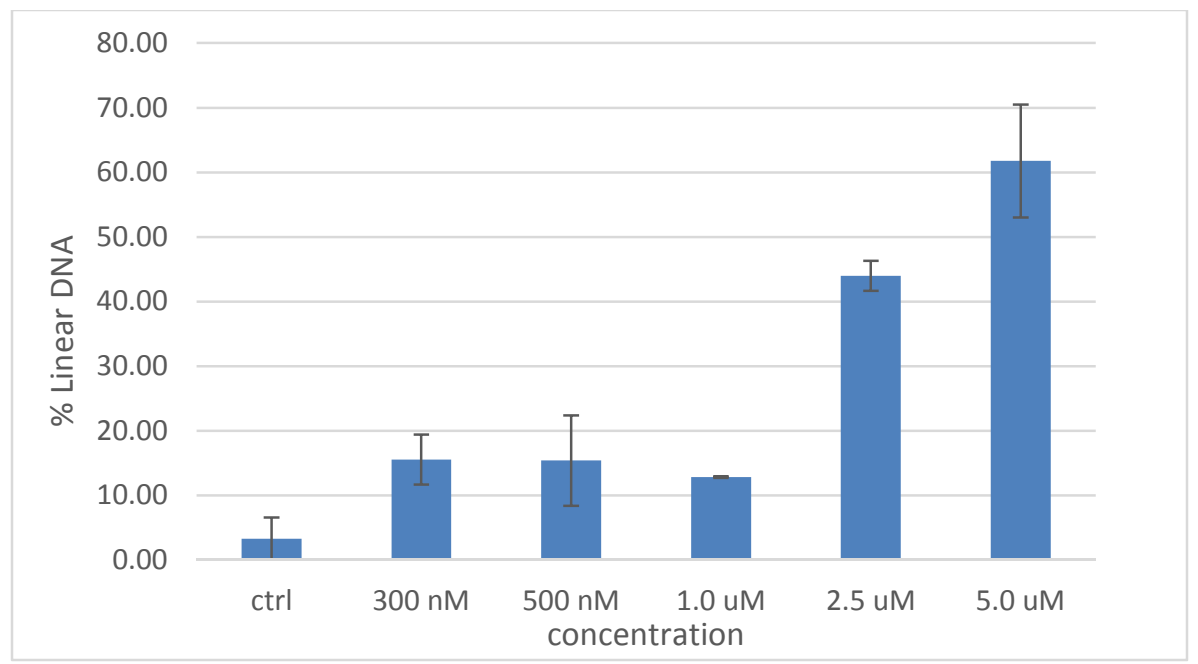

Figure 50. DNA linearization with increasing concentration of Red2.

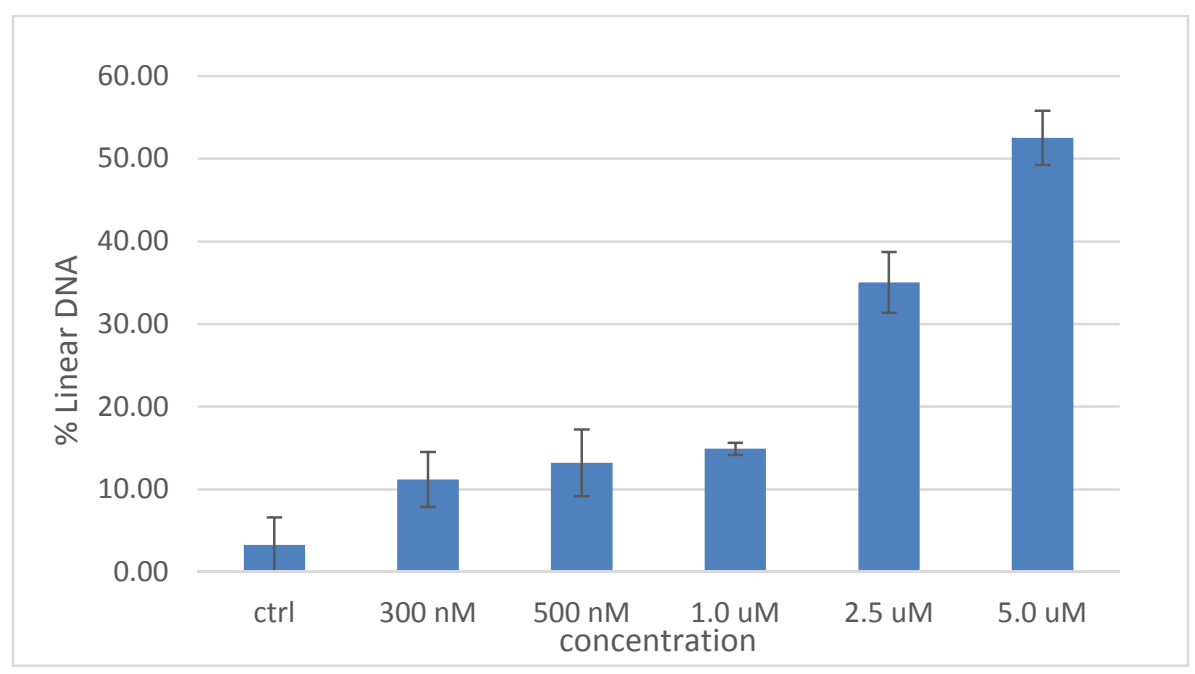

Figure 51. DNA linearization with increasing concentration of 4. 


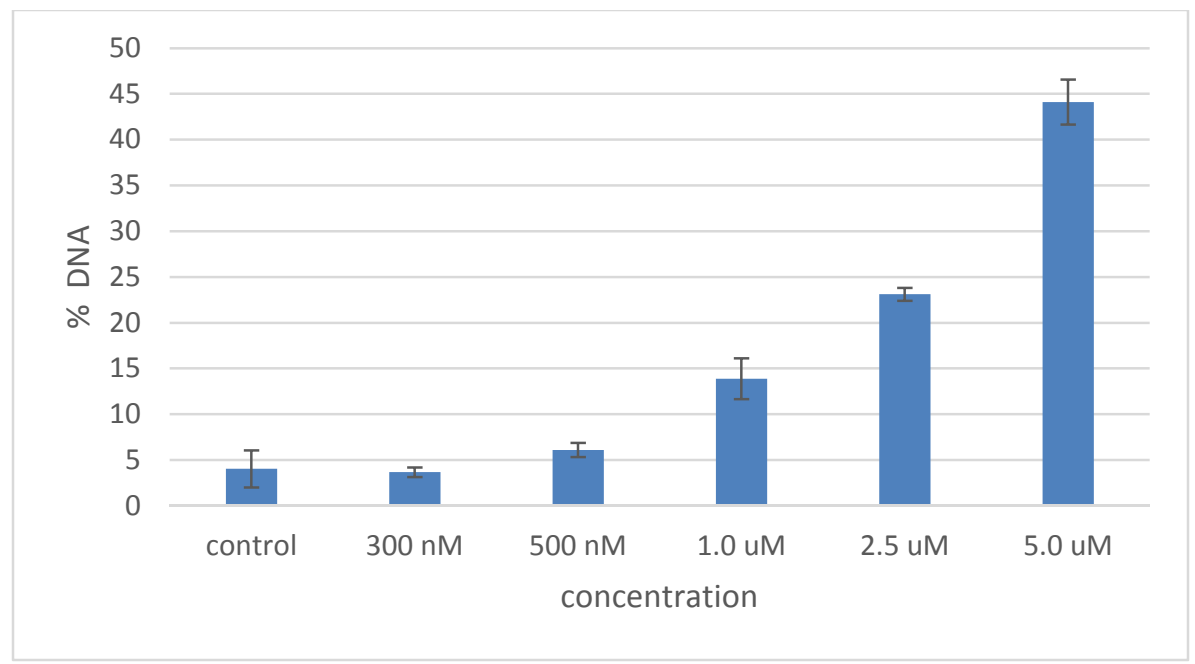

Figure 52. DNA linearization with increasing concentration of 7.

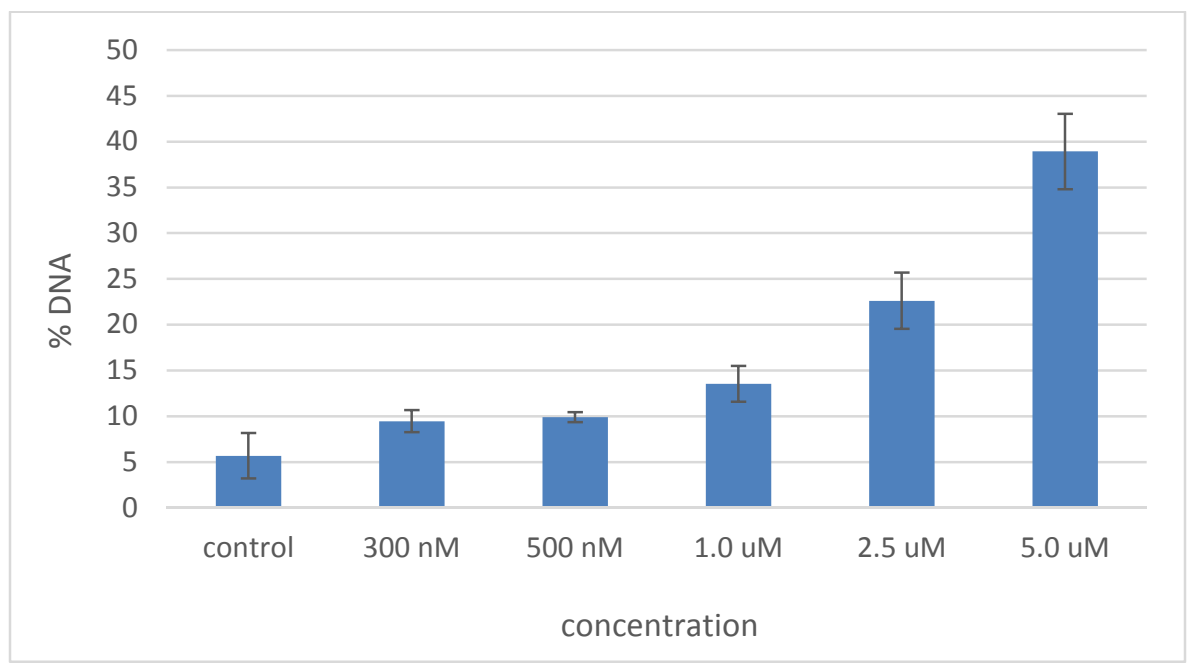

Figure 53. DNA linearization with increasing concentration of 10. 
The representative plots in figures $50-53$ are for a natural prodigiosin (red2), prodigiosin analogues $(4, \mathbf{1 0})$, a tambjamine analogue $(\mathbf{7})$. Although we observed a concentration dependent increase in linearization, we also came to the conclusion that observing the end point, after a one hour incubation, would limit the information that can be gained from linearization experiments as there was no significant difference among the analogues in the amount of DNA converted to linear form. This led to the time dependent experiments in an effort to determine if there were any differences in their activities.

\section{Time Dependent DNA Linearization}

Time dependent DNA cleavage was studied using supercoiled pUC19 DNA. Representative gels from time dependent linearization of supercoiled DNA are shown in figures 54 and 55 . An examination of the gels showed that the cleavage of DNA is time dependent and an interesting feature observed in all the gels was the occurrence of form II DNA from time $=0 \mathrm{~min}$. However there was no increase in form III DNA until at least time $=20$ min with significant form III DNA observed at $20 \mathrm{~min}$. This suggests a delayed reaction, i.e. a two-step process, with the slow step being the rate determining step and concentration dependent. Analysis of the gels (Figures 54 and 55) also suggests that the compounds are able to perform successive single strand cleavage as well as direct double strand cleavage as evidenced by the presence of form II DNA from time $=0 \mathrm{~min}$ but not form III DNA which only becomes visible on the gels at time $=20$ min suggesting that the 
linearization of DNA does not necessarily go in the order supercoiled $\rightarrow$ open circular $\rightarrow$ linear as previously suggested in figure 31 . In addition the observation of a single, well defined linear DNA band on the gel suggests that the cleavage of DNA is not a random process because random cleavage would be expected to produce multiple bands or a smear of linear DNA fragments.

The data from time dependent linearization of supercoiled to form III in the assays containing $\mathrm{Cu}(\mathrm{OAc})_{2}$ was plotted as a function of time and is shown by the representative plots in figures $56-57$.

DNA cleavage reactions with $\mathrm{Zn}^{2+}$ under physiological conditions showed no linearization of DNA with concentrations of both $\mathrm{Zn}^{2+}$ and analogue of up to $20 \mu \mathrm{M}$ (8 times the concentration used for cleavage with $\mathrm{Cu}^{2+}$ ) (Figure 56). This observation suggests that any $\mathrm{Zn}^{2+}$ complexes formed merely bind to DNA as indicated by UV-vis data but do not cleave DNA. 


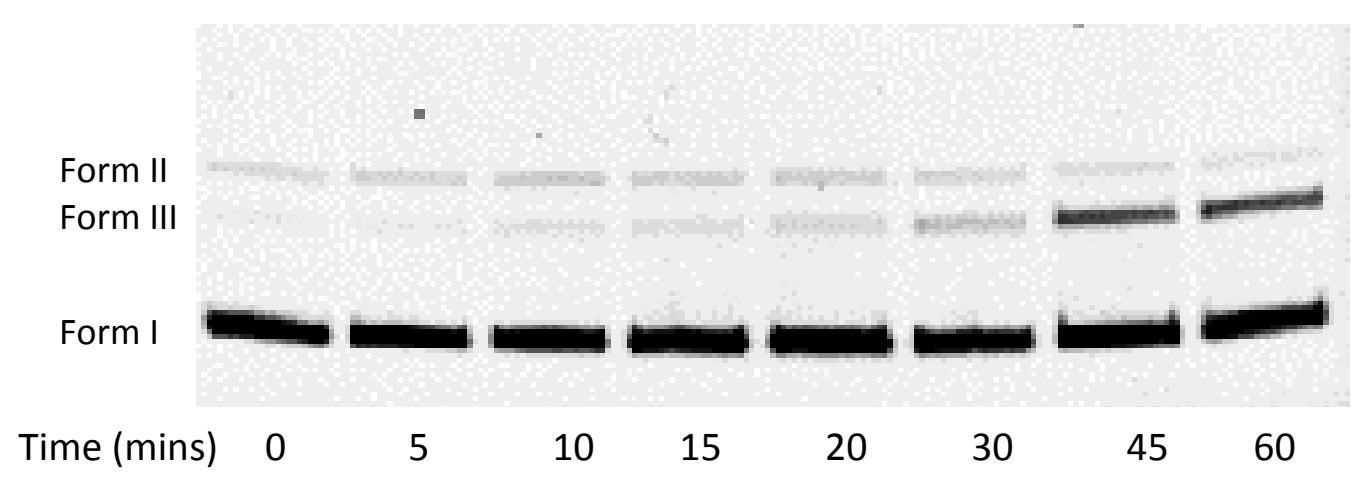

Figure 54. Ethidium bromide stained agarose gel showing time dependent cleavage of supercoiled pUC19 DNA (8.5 nM). In a reaction containing $2.5 \mu \mathrm{M} \mathbf{6}$, $2.5 \mu \mathrm{M} \mathrm{Cu}(\mathrm{OAc})_{2}$ and $25 \mu \mathrm{M} \mathrm{H}_{2} \mathrm{O}_{2}$.

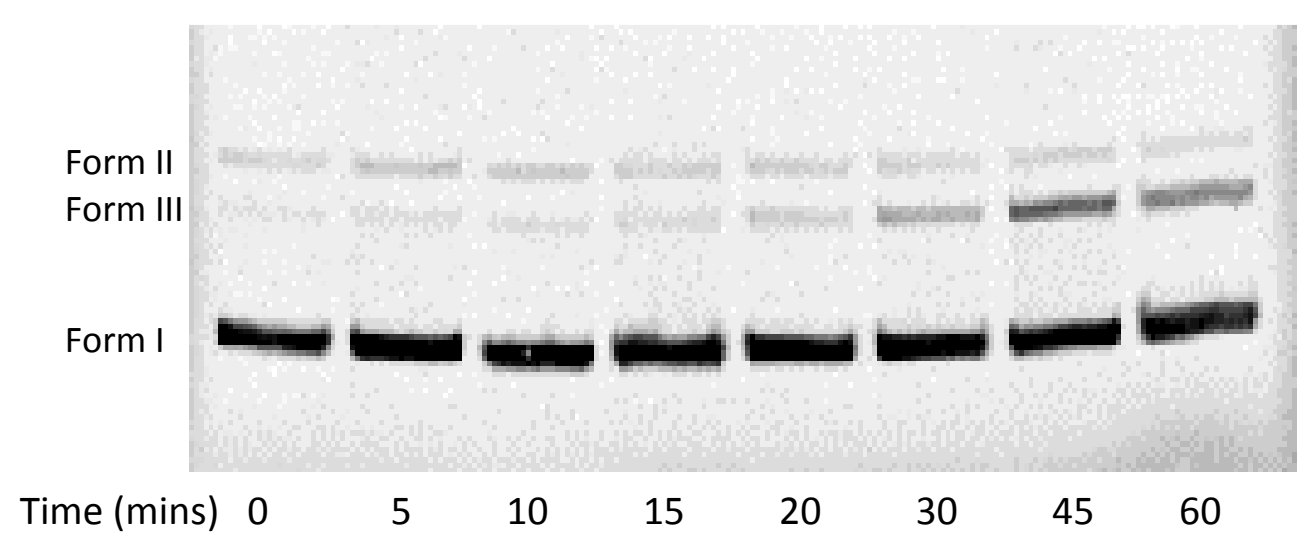

Figure 55. Ethidium bromide stained agarose gel showing time dependent cleavage of supercoiled pUC19 DNA $(8.5 \mathrm{nM})$. In a reaction containing $2.5 \mu \mathrm{M} 10$, $2.5 \mu \mathrm{M} \mathrm{Cu}(\mathrm{OAc})_{2}$ and $25 \mu \mathrm{M} \mathrm{H}_{2} \mathrm{O}_{2}$. 


\begin{tabular}{|c|c|c|c|c|c|c|c|c|}
\hline & \multicolumn{4}{|c|}{ Compound 4} & \multicolumn{4}{|c|}{ Compound 3} \\
\hline & $2.5 \mu \mathrm{M}$ & $5.0 \mu \mathrm{M}$ & $10 \mu \mathrm{M}$ & $20 \mu \mathrm{M}$ & $2.5 \mu \mathrm{M}$ & $5.0 \mu \mathrm{M}$ & $10 \mu \mathrm{M}$ & $20 \mu \mathrm{M}$ \\
\hline & + & + & + & + & + & + & + & + \\
\hline & + & + & + & + & + & + & + & + \\
\hline & + & + & + & + & + & + & + & + \\
\hline
\end{tabular}

Figure 56. Representative ethidium bromide stained agarose gel showing pUC19 DNA in a reaction containing increasing concentrations of 4 (lanes1-4) and 3 lanes (5-8) with equimolar concentrations of $\mathrm{Zn}(\mathrm{OAc})_{2}$ and $25 \mu \mathrm{M} \mathrm{H}_{2} \mathrm{O}_{2}$.

Analysis of the data revealed that linearization of DNA by prodigiosin and tambjamine analogues in the presence of $\mathrm{Cu}^{2+}$ is a two-step process. The gel shift data suggests that the reaction has a slow and fast step that likely involves a slow binding step to DNA which is concentration dependent and a fast nicking step of SC DNA to either form II or form III but does not seem to necessarily go through relaxation of supercoiled DNA (form I) to nicked or OC DNA (form II) followed linearization to form III.

$$
\text { form I DNA } \stackrel{-\mathrm{k}_{1}}{\rightarrow} \text { intermediate }-\underset{\mathrm{k}_{2}}{-\rightarrow} \text { form II }
$$


Where $k_{1}$ and $k_{2}$ are rate constants for the first and second steps. If $k_{2}>>k_{1}, k_{1}$ being the slow step becomes the rate determining step and the rate of cleavage of DNA becomes independent of $k_{2}$.

The rate constant for the linearization of DNA can be determined from fitting to the equation: $y=A o\left(1-e^{-k_{1} t}\right)$.
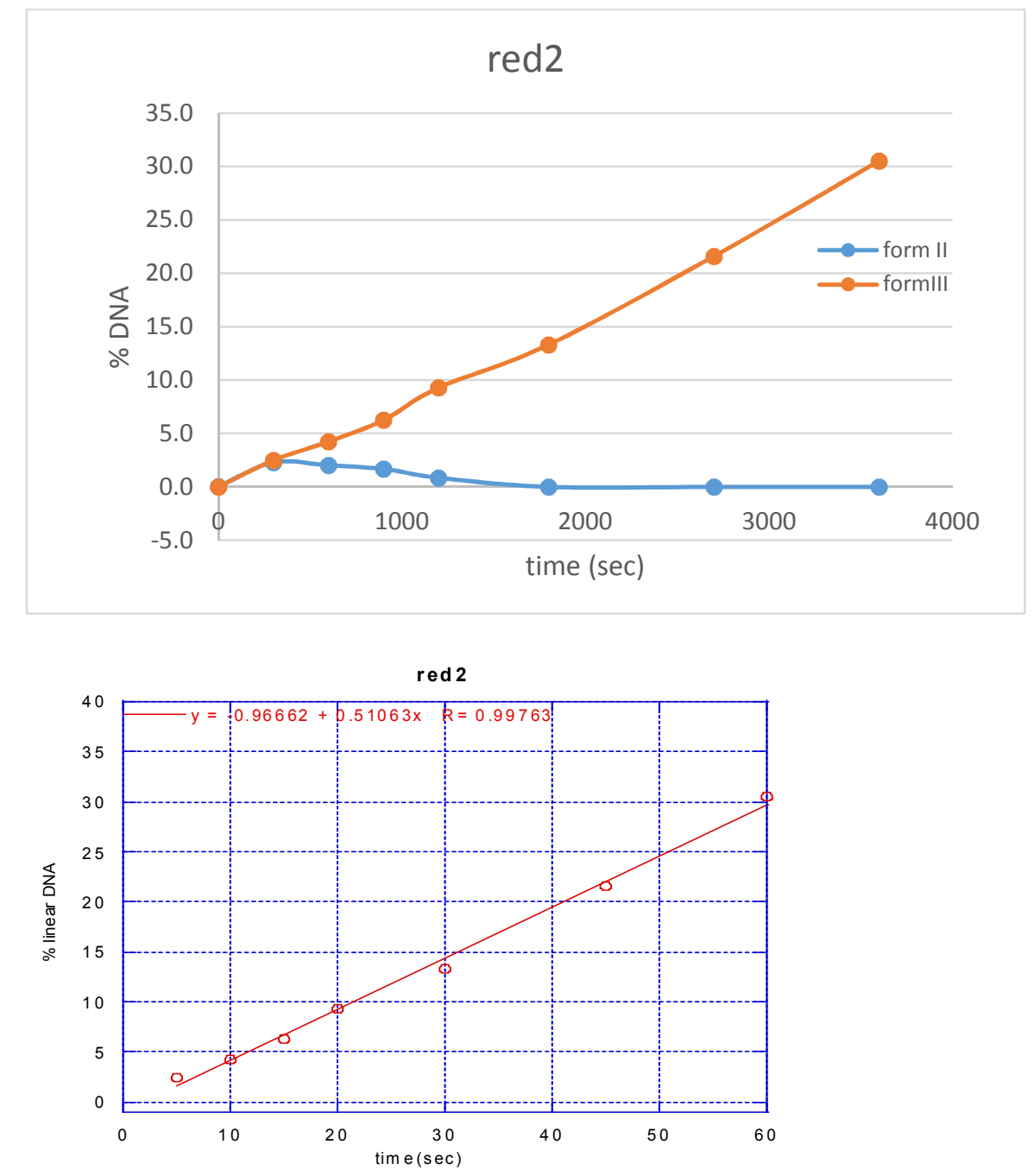

Figure 57. Time dependent pUC19 DNA cleavage with corresponding kaleidagraph plot for red2. 
The red2 data fit poorly to the first order reaction model and was therefore fit to a linear equation with the rate of linearization for red2 being determined from the slope of the linear equation. This is in contrast to what was observed for the rest of the compounds in which an initial lag was observed in the formation of form III DNA (Figure 58), although an intermediate form II DNA was present. As with red2, these observations suggest a two-step process except that in the case of compounds 1-10, the first event is a slow step and the subsequent step is much faster $\left(k_{2}>>k_{1}\right)$. The initial lag phase likely corresponds to the DNA binding step or the first cleavage event as the lag was still observed when the compounds were preincubated with $\mathrm{Cu}^{2+}$ for 30 mins before addition of plasmid DNA (data not shown). However, the appearance of form II during this initial lag phase suggests that the conversion of form II DNA to form III DNA is not the fast step as we would expect to see form II DNA decreasing significantly while form III DNA increases. However, this is not apparent on the gels and suggests that both single and direct double strand scission are occurring simultaneously. 

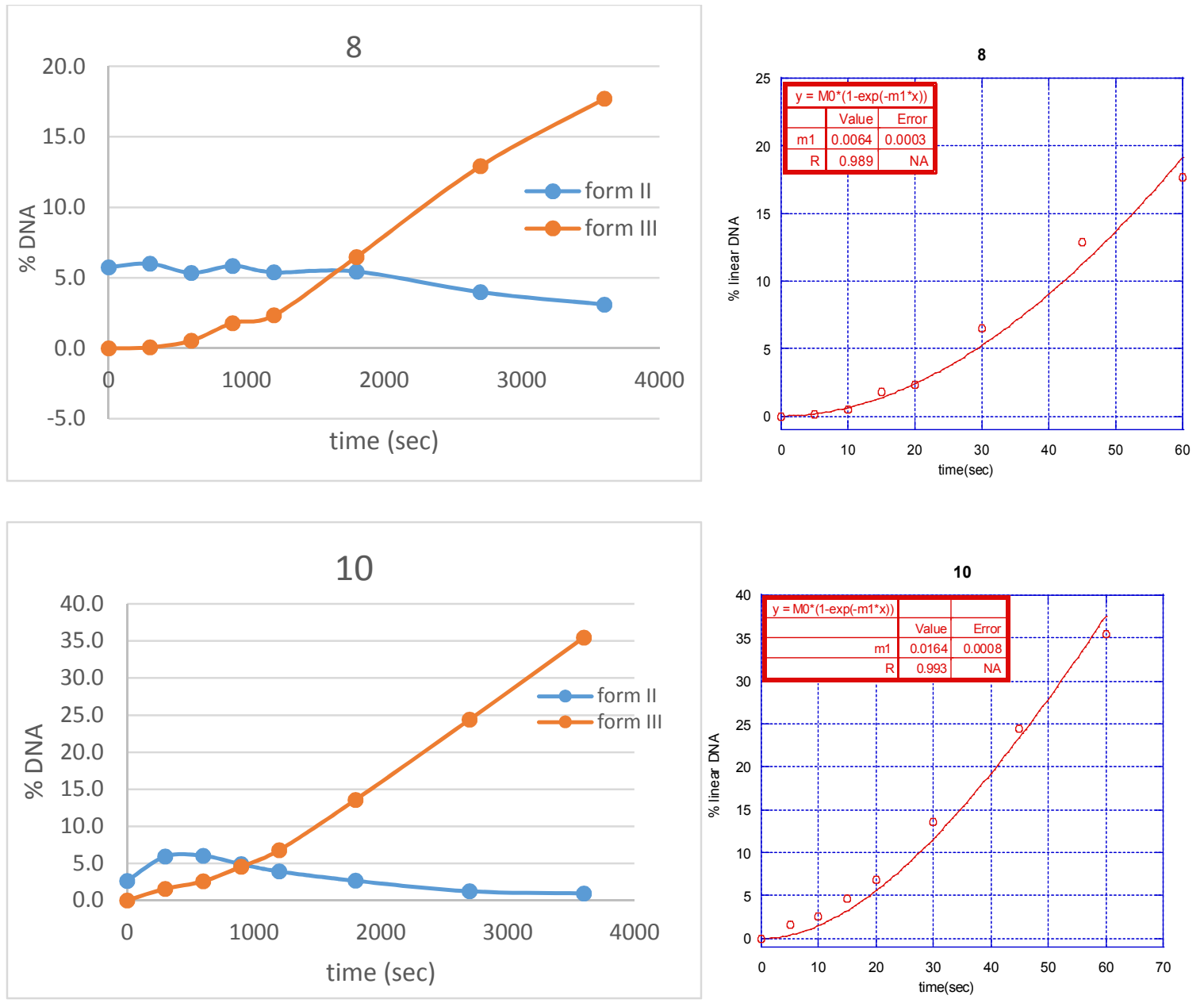

Figure 58. Time dependent pUC19 DNA cleavage with corresponding Kaleidagraph plot for 8 (top panel) and 10 (bottom panel).

Figure 59 shows a representative plot the effect of ionic strength on DNA linearization. These experiments were carried out in the same buffer containing either $50 \mathrm{mM}$ or $100 \mathrm{mM} \mathrm{NaCl}$. As expected, the higher ionic strength led to decreased conversion of supercoiled DNA to linear form (Table 3). This is due to the stabilizing effect of the salt on DNA making the DNA backbone less accessible to the $\mathrm{PgCu}$ complexes. 


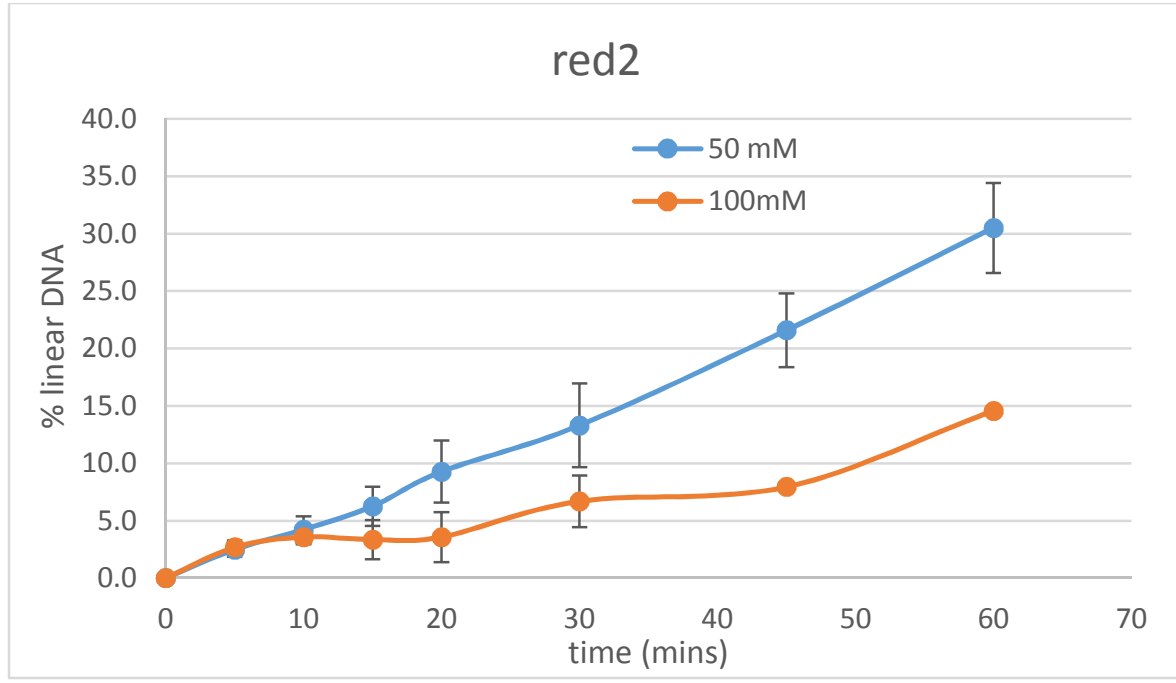

Figure 59. Effect of increasing ionic strength on rate of DNA linearization by red2.

Table 3. Rate constants of DNA linearization

$50 \mathrm{mM} \mathrm{NaCl}$

\begin{tabular}{l|ll|l|l} 
compound & $k_{\text {lin }}\left(\mathrm{min}^{-1}\right)$ & stdev & $k_{\text {lin }}(\mathbf{1}) / k_{\text {lin }}$ & \\
$\mathbf{1}$ & 0.0127 & 0.0008 & 1 \\
$\mathbf{2}$ & 0.0097 & 0.0008 & 1.3 \\
$\mathbf{3}$ & 0.0094 & 0.0004 & 1.4 \\
$\mathbf{4}$ & 0.0166 & 0.0014 & 0.8 & 0.0 \\
$\mathbf{5}$ & 0.0112 & 0.0006 & 1.1 \\
$\mathbf{6}$ & 0.0137 & 0.0007 & 0.9 & \\
$\mathbf{7}$ & 0.0153 & 0.0006 & 0.8 & 0.0 \\
$\mathbf{8}$ & 0.0064 & 0.0003 & 1.9 & 0.0 \\
$\mathbf{9}$ & 0.0041 & 0.0002 & 3.1 & $\mathrm{ND}$ \\
$\mathbf{1 0}$ & 0.0164 & 0.0008 & 0.8 & 0.0
\end{tabular}

$100 \mathrm{mM} \mathrm{NaCl}$

\begin{tabular}{|ll|l} 
Klin $\left(\mathrm{min}^{-1}\right)$ & stdev & $\mathrm{K}_{\text {lin }}(\mathbf{1}) / \mathrm{k}_{\text {lin }}$ \\
0.0035 & 0.0003 & 1 \\
0.0013 & 0.0001 & 2.7 \\
$\mathrm{ND}$ & & \\
0.0032 & 0.0003 & 1.1 \\
$\mathrm{ND}$ & & \\
0.0042 & 0.0002 & 0.8 \\
0.0034 & 0.00008 & 1 \\
0.0027 & 0.00009 & 1.3 \\
$\mathrm{ND}$ & & \\
0.0025 & 0.0001 & 1.4
\end{tabular}

$\mathrm{k}_{\text {lin }}=$ rate constant of DNA linearization 
The rate constants for DNA linearization are shown in table 3 and expressed as $\min ^{-1}$. These rate constants are determined by the slow step which is the binding step and so reflect the rate of metal complex binding to DNA. The rates were essentially similar except for compounds $\mathbf{8}$ and $\mathbf{9}$, both tambjamines with -OMe group substituted with small alkyl groups, which were $\sim 2-3$ fold faster in the lower (50 $\mathrm{mM})$ ionic strength buffer.

\section{Discussion and Conclusion}

Both natural and synthetic prodigiosins and tambjamines have a wide variety of biological activities. We measured the $\mathrm{pK}_{\mathrm{a}}$ of the analogues and looked at their metal binding properties. The data indicate very small changes in $\mathrm{pK}_{\mathrm{a}}$ which made it difficult to discern any useful relationship between pKa and structure and suggests that the substituents on the pyrrole rings of these compounds had very little effect on their ionization potential. The prodigiosins and tambjamines have been shown to interact with DNA and cause DNA cleavage. The ability of these compounds to mediate DNA cleavage can help to explain some of their biological activity. Double-stranded DNA cleavage cannot be easily repaired and is therefore more desired from the standpoint of anti-cancer drug development for any DNAcleaving metal complex. Our analogues showed mixed modes of DNA binding, not related to their structure; the different binding modes observed with $\mathbf{r e d} 2 \cdot \mathbf{C u}$ and 1. Cu in particular were unexpected since the difference in these 2 compounds (the C-ring substituents) is not expected to affect their planarity. In addition all the 
analogues showed efficient DNA cleavage in the presence of $\mathrm{Cu}^{2+}$ regardless of the observed DNA interaction by UV-Vis experiment suggesting that mode of binding does not determine cleavage activity. The cleavage of DNA was both concentration and time dependent with an initial lag phase suggesting a two-step process; a PgCu-DNA binding step followed by the cleavage reaction. The absence of smearing or fragments of linear DNA on the agarose gels suggests that there is a single linear cleavage product suggesting that the complexes only perform a single cut. Furthermore, we have proposed that the lag phase observed in the cleavage experiments is due to the binding of the complex to DNA and this could explain the lack of other fragments of linear DNA as the experiments where only carried out over one hour and so additional cleavage events would require another binding event which is slow and would not be observable in the time that the experiment was conducted. Experiments with ssDNA showed that these compounds do not cleave ssDNA (data not shown) suggesting that they require some secondary structure for cleavage activity. It is interesting to note that the UVVis DNA binding data suggested that the compounds interact with DNA mostly by groove binding in dsDNA. Single stranded DNA does not adopt a helical formation and this is further support of our explanation as to why we did not observe any cleavage of ssDNA. Based on these observations we propose a revised model for cleavage of DNA in figure 60 below; 


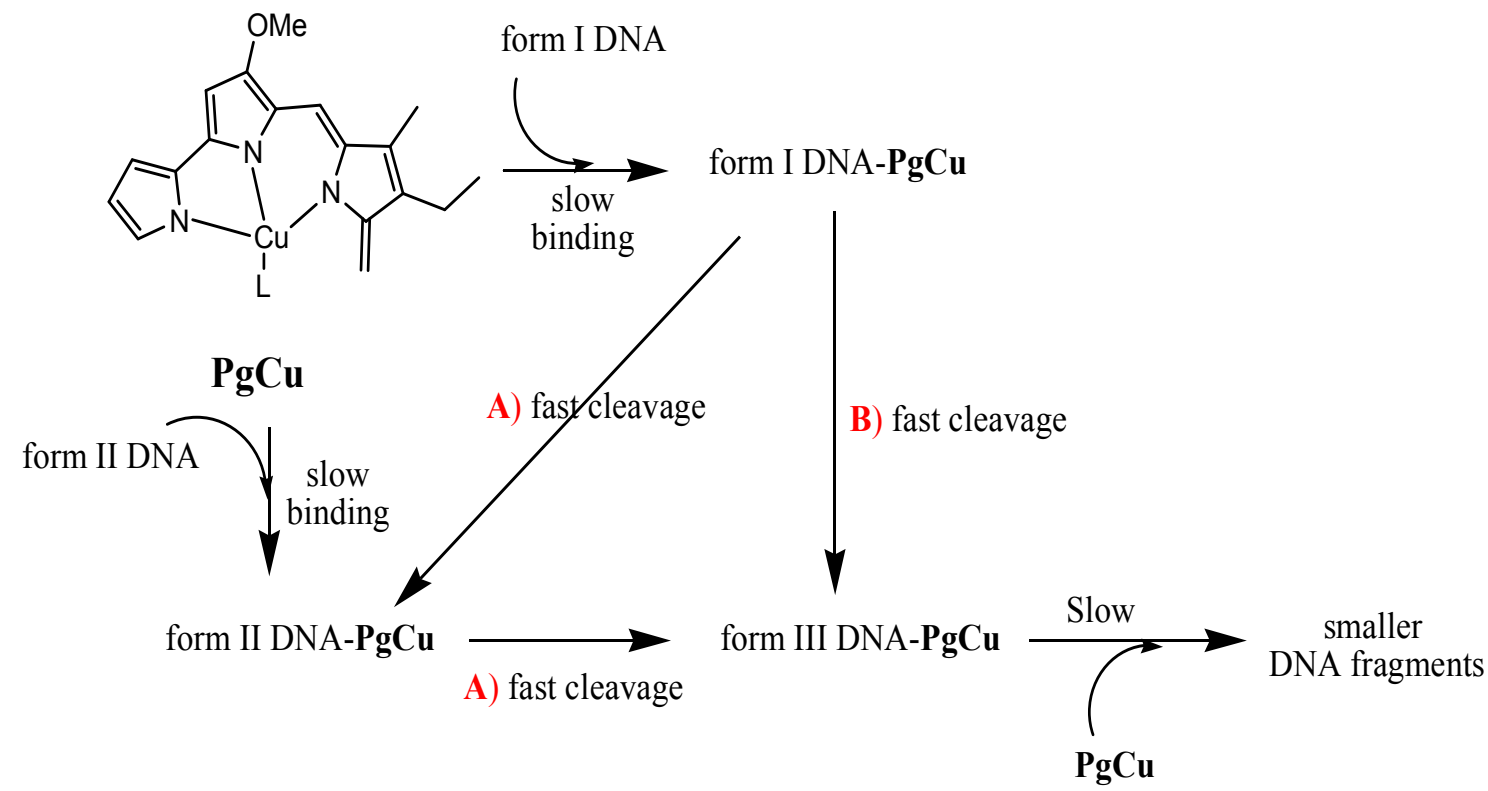

Figure 60. Revised model for the cleavage of DNA by prodigiosin and tambjamine analogues in the presence of $\mathrm{Cu}^{2+}$. The slow binding event is followed by fast cleavage events of either a single nick (A) or direct double strand cleavage (B).

There was no cleavage activity was observed with $\mathrm{Zn}^{2+}$. Since $\mathrm{Zn}^{2+}$ is redox inactive this observation was not unexpected even though there are some reports that have implicated $\mathrm{Zn}^{2+}$ in DNA damage through a hydrolytic mechanism ${ }^{86,87}$. In chapter 2 we proposed a mechanism for generation of a $\mathrm{Pg}-\mathrm{Cu}-\mathrm{OOH}$ complex able to cause the DNA damage either directly by attack on the phosphate group on the DNA backbone or through generation of a short-lived hydroxyl radical (fig 29). The data suggests that either concentration of $\mathrm{Pg}$ or $\mathrm{Tm}$ is limiting or that the $\mathrm{Pg} / \mathrm{Tm}$ metal complex once bound to DNA is not released since we did not observe smaller fragments of linear DNA suggesting that there is one cleavage event on both strands. However, despite the DNA cleavage activity of prodigiosin and tambjamine analogues in the presence of $\mathrm{Cu}^{2+}$ and $\mathrm{H}_{2} \mathrm{O}_{2}$ there was no trend 
observed between the structure of the analogues and DNA cleavage activity. Recent data shows that these compounds have markedly different antimalarial activities $^{17,64}$. The DNA cleavage data also did not correlate with antimalarial activity of these compounds and this suggests the antimalarial activity is not through $\mathrm{Cu}^{2+}$ mediated DNA cleavage by $\mathrm{Pg}$ and $\mathrm{Tm}$ compounds. However, the fact that these compounds cause dsDNA damage raises concerns on their suitability for use in treatment of diseases. 


\section{References}

1. D'Addario, G.; Pintilie, M.; Leighl, N. B.; Feld, R.; Cerny, T.; Shepherd, F. A., Platinum-based versus non-platinum-based chemotherapy in advanced non-small-cell lung cancer: a meta-analysis of the published literature. In J Clin Oncol, United States, 2005; Vol. 23, pp 2926-36.

2. Chen, J.; Yin, J.; Li, X.; Wang, Y.; Zheng, Y.; Qian, C.; Xiao, L.; Zou, T.; Wang, Z.; Liu, J.; Zhang, W.; Zhou, H.; Liu, Z., WISP1 polymorphisms contribute to platinum-based chemotherapy toxicity in lung cancer patients. In Int J Mol Sci, Switzerland, 2014; Vol. 15, pp 21011-27.

3. Hoeijmakers, J. H., DNA damage, aging, and cancer. In N Engl J Med, United States, 2009; Vol. 361, pp 1475-85.

4. Ciccia, A.; Elledge, S. J., The DNA damage response: making it safe to play with knives. In Mol Cell, 2010 Elsevier Inc: United States, 2010; Vol. 40, pp 179-204.

5. Liu, P.; Wang, Y.-y.; Qi, X.; Gu, Q.; Geng, M.; Li, J., Undecylprodigiosin Induced Apoptosis in P388 Cancer Cells Is Associated with Its Binding to Ribosome. PLoS ONE 2013, $8(6)$, e65381.

6. Pandey, R.; Chander, R.; Sainis, K. B., Prodigiosins as anti cancer agents: living upto their name. Curr Pharm Des 2009, 15 (7), 732-41.

7. Pérez-Tomás, R.; Montaner, B.; Llagostera, E.; Soto-Cerrato, V., The prodigiosins, proapoptotic drugs with anticancer properties. Biochemical Pharmacology 2003, 66 (8), 1447-1452.

8. Williamson, N. R.; Fineran, P. C.; Leeper, F. J.; Salmond, G. P., The biosynthesis and regulation of bacterial prodiginines. Nat Rev Microbiol 2006, 4 (12), 887-99.

9. Williamson, N. R., Chawrai, S., Leeper, F. J. and Salmond, G. P. C., Prodiginines and Their Potential Utility as Proapoptotic Anticancer Agents, in Emerging Cancer Therapy (eds A. M. Fialho and A. M. Chakrabarty). John Wiley \& Sons, Inc.: Hoboken, New Jersey, 2010.

10. Castro, A.; Deck, J.; Hugo, M.; Williams, L.; Zingg, M., Notes. Prodigiosin Hydrochloride. The Journal of Organic Chemistry 1958, 23 (8), 1232-1233; Castro, A. J.; Deck, J. F.; Hugo, M. T.; Lowe, E. J.; Marsh, J. P.; Pfeiffer, R. J., Prodigiosin1a. The Journal of Organic Chemistry 1963, 28 (3), 857-860.

11. O'Brien, S. M.; Claxton, D. F.; Crump, M.; Faderl, S.; Kipps, T.; Keating, M. J.; Viallet, J.; Cheson, B. D., Phase I study of obatoclax mesylate (GX15-070), a small molecule pan$\mathrm{Bcl}-2$ family antagonist, in patients with advanced chronic lymphocytic leukemia. Blood 2009, 113 (2), 299-305; Paik, P. K.; Rudin, C. M.; Pietanza, M. C.; Brown, A.; Rizvi, N. A.; Takebe, N.; Travis, W.; James, L.; Ginsberg, M. S.; Juergens, R.; Markus, S.; Tyson, L.; Subzwari, S.; Kris, M. G.; Krug, L. M., A phase II study of obatoclax mesylate, a Bcl-2 antagonist, plus topotecan in relapsed small cell lung cancer. Lung Cancer 2011, 74 (3), 481-5. 
12. Papireddy, K.; Smilkstein, M.; Kelly, J. X.; Shweta; Salem, S. M.; Alhamadsheh, M.; Haynes, S. W.; Challis, G. L.; Reynolds, K. A., Antimalarial activity of natural and synthetic prodiginines. J Med Chem 2011, 54 (15), 5296-306.

13. Jenkins, S.; Incarvito, C. D.; Parr, J.; Wasserman, H. H., Structural studies of C-ring substituted unnatural analogues of prodigiosin. CrystEngComm 2009, 11 (2), 242-245.

14. Azuma, T.; Watanabe, N.; Yagisawa, H.; Hirata, H.; Iwamura, M.; Kobayashi, Y., Induction of apoptosis of activated murine splenic $\mathrm{T}$ cells by cycloprodigiosin hydrochloride, a novel immunosuppressant. Immunopharmacology 2000, 46 (1), 29-37.

15. Han, S. B.; Kim, H. M.; Kim, Y. H.; Lee, C. W.; Jang, E.-S.; Son, K. H.; Kim, S. U.; Kim, Y. K., T-cell specific immunosuppression by prodigiosin isolated from Serratia marcescens. International Journal of Immunopharmacology 1998, 20 (1-3), 1-13.

16. Isaka, M.; Jaturapat, A.; Kramyu, J.; Tanticharoen, M.; Thebtaranonth, Y., Potent in vitro antimalarial activity of metacycloprodigiosin isolated from Streptomyces spectabilis BCC 4785. Antimicrob Agents Chemother 2002, 46 (4), 1112-3.

17.

18. Seganish, J. L.; Davis, J. T., Prodigiosin is a chloride carrier that can function as an anion exchanger. Chem Commun (Camb) 2005, (46), 5781-3.

19. Gale, P. A.; Light, M. E.; McNally, B.; Navakhun, K.; Sliwinski, K. E.; Smith, B. D., Cotransport of $\mathrm{H}+/ \mathrm{Cl}$ - by a synthetic prodigiosin mimic. Chem Commun (Camb) 2005, (30), 3773-5.

20. Melvin, M. S.; Calcutt, M. W.; Noftle, R. E.; Manderville, R. A., Influence of the aring on the redox and nuclease properties of the prodigiosins: importance of the bipyrrole moiety in oxidative DNA cleavage. Chem Res Toxicol 2002, 15 (5), 742-8.

21. Harris, A. K.; Williamson, N. R.; Slater, H.; Cox, A.; Abbasi, S.; Foulds, I.; Simonsen, H. T.; Leeper, F. J.; Salmond, G. P., The Serratia gene cluster encoding biosynthesis of the red antibiotic, prodigiosin, shows species- and strain-dependent genome context variation. Microbiology 2004, 150 (Pt 11), 3547-60.

22. Pinkerton, D. M.; Banwell, M. G.; Garson, M. J.; Kumar, N.; de Moraes, M. O.; Cavalcanti, B. C.; Barros, F. W. A.; Pessoa, C., Antimicrobial and Cytotoxic Activities of Synthetically Derived Tambjamines C and E - J, BE-18591, and a Related Alkaloid from the Marine Bacterium Pseudoalteromonas tunicata.

23. Borah, S.; Melvin, M. S.; Lindquist, N.; Manderville, R. A., Copper-mediated nuclease activity of a tambjamine alkaloid. Journal of the American Chemical Society 1998, 120 (19), 4557-4562.

24. Melvin, M. S.; Tomlinson, J. T.; Park, G.; Day, C. S.; Saluta, G. R.; Kucera, G. L.; Manderville, R. A., Influence of the a-ring on the proton affinity and anticancer properties of the prodigiosins. Chem Res Toxicol 2002, 15 (5), 734-41.

25. Park, G.; Tomlinson, J. T.; Melvin, M. S.; Wright, M. W.; Day, C. S.; Manderville, R. A., Zinc and copper complexes of prodigiosin: implications for copper-mediated doublestrand DNA cleavage. Org Lett 2003, 5 (2), 113-6. 
26. van Dam, L.; Levitt, M. H., BII Nucleotides in the B and C Forms of Naturalsequence Polymeric DNA: A New Model for the C Form of DNA. Journal of Molecular Biology 2000, 304 (4), 541-561.

27. www.genome.gov, 2013.

28. Lu, X. J.; Olson, W. K., 3DNA: a software package for the analysis, rebuilding and visualization of three-dimensional nucleic acid structures. Nucleic Acids Research 2003, 31 (17), 5108-5121.

29. Bacolla, A.; Wells, R. D., Non-B DNA conformations, genomic rearrangements, and human disease. In J Biol Chem, United States, 2004; Vol. 279, pp 47411-4.

30. Li, H. H.; Aubrecht, J.; Fornace, A. J., Toxicogenomics: overview and potential applications for the study of non-covalent DNA interacting chemicals. Mutat Res 2007, 623 (1-2), 98-108.

31. Mariappan, M.; Suenaga, M.; Mukhopadhyay, A.; Raghavaiah, P.; Maiya, B. G., Synthesis, structure, DNA binding and photocleavage activity of a ruthenium(II) complex with 11-(9-acridinyl)dipyrido[3,2-a:2',3'-c]phenazine ligand. Inorganica Chimica Acta 2011, 376 (1), 340-349.

32. Hawkins, C. A.; Watson, C.; Yan, Y.; Gong, B.; Wemmer, D. E., Structural analysis of the binding modes of minor groove ligands comprised of disubstituted benzenes. Nucleic Acids Res 2001, 29 (4), 936-42.

33. Xu, H.; Zheng, K.-C.; Chen, Y.; Li, Y.-Z.; Lin, L.-J.; Li, H.; Zhang, P.-X.; Ji, L.-N., Effects of ligand planarity on the interaction of polypyridyl Ru(ii) complexes with DNA. Dalton Transactions 2003, (11), 2260-2268.

34. Xu, H.; Zheng, K. C.; Lin, L. J.; Li, H.; Gao, Y.; Ji, L. N., Effects of the substitution positions of $\mathrm{Br}$ group in intercalative ligand on the DNA-binding behaviors of $\mathrm{Ru}(\mathrm{II})$ polypyridyl complexes. J Inorg Biochem 2004, 98 (1), 87-97.

35. Hajian, R.; Guan Huat, T., Spectrophotometric Studies on the Thermodynamics of the ds-DNA Interaction with Irinotecan for a Better Understanding of Anticancer DrugDNA Interactions. Journal of Spectroscopy 2013, 2013, 8.

36. Sirajuddin, M.; Haider, A.; Ali, S., Analytical Techniques For The Study Of Drug-DNA Interactions. International Journal 2013, 1 (9), 499-509.

37. Palchaudhuri, R.; Hergenrother, P. J., DNA as a target for anticancer compounds: methods to determine the mode of binding and the mechanism of action. Curr Opin Biotechnol 2007, 18 (6), 497-503.

38. Frederickson, C. J.; Koh, J. Y.; Bush, A. I., The neurobiology of zinc in health and disease. In Nat Rev Neurosci, England, 2005; Vol. 6, pp 449-62.

39. Cowan, J. A., Chemical nucleases. Current Opinion in Chemical Biology 2001, 5 (6), 634-642.

40. Liu, C.; Wang, M.; Zhang, T.; Sun, H., DNA hydrolysis promoted by di- and multinuclear metal complexes. Coordination Chemistry Reviews 2004, 248 (1-2), 147-168.

41. Keck MV, L. S., Unwinding of supercoiled DNA by platinum-ethidium related complexes. 1992, 14. 
42. Zhang, C. X.; Lippard, S. J., New metal complexes as potential therapeutics. Current Opinion in Chemical Biology 2003, 7 (4), 481-489.

43. Kellett, A.; Howe, O.; O'Connor, M.; McCann, M.; Creaven, B. S.; McClean, S.; Foltyn-Arfa Kia, A.; Casey, A.; Devereux, M., Radical-induced DNA damage by cytotoxic square-planar copper(II) complexes incorporating o-phthalate and 1,10-phenanthroline or 2,2'-dipyridyl. Free Radical Biology and Medicine 2012, 53 (3), 564-576.

44. Wu JC, K. J. a. S. J., Mechanism of Bleomycin: evidence for a rate determining 4' hydrogen abstraction from poly $(\mathrm{dA}-\mathrm{dU})$ associated with the formation of both free base and base propenal. 1985, 24.

45. Cooke, M. S.; Evans, M. D.; Dizdaroglu, M.; Lunec, J., Oxidative DNA damage: mechanisms, mutation, and disease. FASEB J 2003, 17 (10), 1195-214.

46. Kehrer, J. P., The Haber-Weiss reaction and mechanisms of toxicity. Toxicology 2000, 149 (1), 43-50.

47. Sharma, P.; Jha, A. B.; Dubey, R. S.; Pessarakli, M., Reactive Oxygen Species, Oxidative Damage, and Antioxidative Defense Mechanism in Plants under Stressful Conditions. Journal of Botany 2012, 2012, 26.

48. Lord, C. J.; Ashworth, A., The DNA damage response and cancer therapy. Nature 2012, 481 (7381), 287-94.

49. Wiseman, H.; Halliwell, B., Damage to DNA by reactive oxygen and nitrogen species: role in inflammatory disease and progression to cancer. Biochem J 1996, 313 ( Pt 1), 17-29.

50. Turrens, J. F., Mitochondrial formation of reactive oxygen species. The Journal of Physiology 2003, 552 (2), 335-344.

51. Burdon, R. H., Superoxide and hydrogen peroxide in relation to mammalian cell proliferation. In Free Radic Biol Med, United States, 1995; Vol. 18, pp 775-94.

52. Goustin, A. S.; Leof, E. B.; Shipley, G. D.; Moses, H. L., Growth factors and cancer. Cancer Res 1986, 46 (3), 1015-29.

53. López-Lázaro, M., Dual role of hydrogen peroxide in cancer: Possible relevance to cancer chemoprevention and therapy. Cancer Letters 2007, 252 (1), 1-8.

54. Droge, W., Free radicals in the physiological control of cell function. Physiol Rev 2002, 82 (1), 47-95.

55. Angele-Martinez, C.; Goodman, C.; Brumaghim, J., Metal-mediated DNA damage and cell death: mechanisms, detection methods, and cellular consequences. Metallomics 2014, 6 (8), 1358-81.

56. Ding, X.; Xie, H.; Kang, Y. J., The significance of copper chelators in clinical and experimental application. The Journal of Nutritional Biochemistry 2011, 22 (4), 301-310.

57. Cobine, P. A.; Pierrel, F.; Winge, D. R., Copper trafficking to the mitochondrion and assembly of copper metalloenzymes. Biochimica et Biophysica Acta (BBA) - Molecular Cell Research 2006, 1763 (7), 759-772.

58. Zhu, Z.; Labbé, S.; Peña, M. M. O.; Thiele, D. J., Copper Differentially Regulates the Activity and Degradation of Yeast Mac1 Transcription Factor. Journal of Biological Chemistry 1998, 273 (3), 1277-1280. 
59. Macomber, L.; Rensing, C.; Imlay, J. A., Intracellular Copper Does Not Catalyze the Formation of Oxidative DNA Damage in Escherichia coli. Journal of Bacteriology 2007, 189 (5), 1616-1626.

60. Ruiz, R.; García, B.; Garcia-Tojal, J.; Busto, N.; Ibeas, S.; Leal, J. M.; Martins, C.; Gaspar, J.; Borrás, J.; Gil-García, R.; González-Alvarez, M., Biological assays and noncovalent interactions of pyridine-2-carbaldehyde thiosemicarbazonecopper(II) drugs with [poly(dA-dT)](2), [poly(dG-dC)] (2), and calf thymus DNA. J Biol Inorg Chem 2010, 15 (4), 515-32.

61. Jun, T.; Bochu, W.; Liancai, Z., Hydrolytic cleavage of DNA by quercetin zinc(II) complex. Bioorganic \& Medicinal Chemistry Letters 2007, 17 (5), 1197-1199.

62. Wang, X.-Y.; Zhang, J.; Li, K.; Jiang, N.; Chen, S.-Y.; Lin, H.-H.; Huang, Y.; Ma, L.-J.; $\mathrm{Yu}, \mathrm{X} . \mathrm{-Q}$., Synthesis and DNA cleavage activities of mononuclear macrocyclic polyamine zinc(II), copper(II), cobalt(II) complexes which linked with uracil. Bioorganic \& Medicinal Chemistry 2006, 14 (19), 6745-6751.

63. An, Y.; Lin, Y. Y.; Wang, H.; Sun, H. Z.; Tong, M. L.; Ji, L. N.; Mao, Z. W., Cleavage of double-strand DNA by zinc complexes of dicationic 2,2'-dipyridyl derivatives. Dalton Trans 2007, (12), 1250-4.

64. Kancharla, P.; Lu, W.; Salem, S. M.; Kelly, J. X.; Reynolds, K. A., Stereospecific Synthesis of 23-Hydroxyundecylprodiginines and Analogues and Conversion to Antimalarial Premarineosins via a Rieske Oxygenase Catalyzed Bicyclization. The Journal of Organic Chemistry 2014, 79 (23), 11674-11689.

65. Diaz, R. I.; Regourd, J.; Santacroce, P. V.; Davis, J. T.; Jakeman, D. L.; Thompson, A., Chloride anion transport and copper-mediated DNA cleavage by $\mathrm{C}$-ring functionalized prodigiosenes. Chem Commun (Camb) 2007, (26), 2701-3.

66. Melvin, M. S.; Wooton, K. E.; Rich, C. C.; Saluta, G. R.; Kucera, G. L.; Lindquist, N.; Manderville, R. A., Copper-nuclease efficiency correlates with cytotoxicity for the 4methoxypyrrolic natural products. J Inorg Biochem 2001, 87 (3), 129-35.

67. Tisato, F.; Marzano, C.; Porchia, M.; Pellei, M.; Santini, C., Copper in diseases and treatments, and copper-based anticancer strategies. Med Res Rev 2010, 30 (4), 708-49.

68. Barry, N. P.; Edafe, F.; Therrien, B., Anticancer activity of tetracationic arene ruthenium metalla-cycles. Dalton Trans 2011, 40 (27), 7172-80.

69. Keck, M. V.; Lippard, S. J., Unwinding of supercoiled DNA by platinum-ethidium and related complexes. Journal of the American Chemical Society 1992, 114 (9), 33863390.

70. Milacic, V.; Chen, D.; Giovagnini, L.; Diez, A.; Fregona, D.; Dou, Q. P., Pyrrolidine dithiocarbamate-zinc(II) and-copper(II) complexes induce apoptosis in tumor cells by inhibiting the proteasomal activity(). Toxicology and applied pharmacology 2008, 231 (1), 24-33.

71. Hartinger, C. G.; Zorbas-Seifried, S.; Jakupec, M. A.; Kynast, B.; Zorbas, H.; Keppler, B. K., From bench to bedside--preclinical and early clinical development of the anticancer agent indazolium trans-[tetrachlorobis(1H-indazole)ruthenate(III)] (KP1019 or FFC14A). J Inorg Biochem 2006, 100 (5-6), 891-904. 
72. Regourd, J.; Al-Sheikh Ali, A.; Thompson, A., Synthesis and Anti-Cancer Activity of C-Ring-Functionalized Prodigiosin Analogues. Journal of Medicinal Chemistry 2007, 50 (7), 1528-1536.

73. Dairi, K.; Tripathy, S.; Attardo, G.; Lavallée, J.-F., Two-step synthesis of the bipyrrole precursor of prodigiosins. Tetrahedron Letters 2006, 47 (15), 2605-2606.

74. Heaton, P. a. K., JT, DNA Quantification. In Essentials of Nucleic Acid Analysis, Keer, J. a. B., L, Ed. Royal Society of Chemistry: Cambridge, 2008; pp 83-100.

75. Carbone, A.; Fioretti, F. M.; Fucci, L.; Ausió, J.; Piscopo, M., High efficiency method to obtain supercoiled DNA with a commercial plasmid purification kit. Acta Biochim Pol 2012, 59 (2), 275-8.

76. Ameta, R. K.; Singh, M.; Kale, R. K., Synthesis and structure-activity relationship of benzylamine supported platinum(iv) complexes. New Journal of Chemistry 2013, 37 (5), 1501-1508.

77. Manderville, R. A.; Wade Calcutt, M.; Dai, J.; Park, G.; Gillman, I. G.; Noftle, R. E.; Mohammed, A. K.; Birincioglu, M.; Dizdaroglu, M.; Rodriguez, H.; Akman, S. A., Stoichiometric preference in copper-promoted oxidative DNA damage by ochratoxin A. $J$ Inorg Biochem 2003, 95 (2-3), 87-96.

78. Rajarajeswari, C.; Ganeshpandian, M.; Palaniandavar, M.; Riyasdeen, A.; Akbarsha, M. A., Mixed ligand copper(II) complexes of 1,10-phenanthroline with tridentate phenolate/pyridyl/(benz)imidazolyl Schiff base ligands: covalent vs non-covalent DNA binding, DNA cleavage and cytotoxicity. J Inorg Biochem 2014, 140, 255-68.

79. LePecq, J. B.; Paoletti, C., A fluorescent complex between ethidium bromide and nucleic acids. Physical-chemical characterization. In J Mol Biol, England, 1967; Vol. 27, pp 87-106.

80. Melvin, M. S.; Ferguson, D. C.; Lindquist, N.; Manderville, R. A., DNA Binding by 4Methoxypyrrolic Natural Products. Preference for Intercalation at AT Sites by Tambjamine E and Prodigiosin. J Org Chem 1999, 64 (18), 6861-6869.

81. Chang, T. M.; Sinharay, S.; Astashkin, A. V.; Tomat, E., Prodigiosin analogue designed for metal coordination: stable zinc and copper pyrrolyldipyrrins. Inorg Chem 2014, 53 (14), 7518-26.

82. Cusumano, M.; Di Pietro, M. L.; Giannetto, A.; Nicolo, F.; Rotondo, E., Noncovalent Interactions of Platinum(II) Square Planar Complexes Containing Ligands Out-of-Plane with DNA. In Inorg Chem, 1998; Vol. 37, pp 563-568.

83. Lippard, S. J., Platinum complexes: probes of polynucleotide structure and antitumor drugs. Accounts of Chemical Research 1978, 11 (5), 211-217.

84. Shahabadi, N.; Kashanian, S.; Mahdavi, M.; Sourinejad, N., DNA Interaction and DNA Cleavage Studies of a New Platinum(II) Complex Containing Aliphatic and Aromatic Dinitrogen Ligands. Bioinorg Chem Appl 2011, 2011, 525794.

85. Gupta, R. K.; Pandey, R.; Sharma, G.; Prasad, R.; Koch, B.; Srikrishna, S.; Li, P. Z.; Xu, Q.; Pandey, D. S., DNA binding and anti-cancer activity of redox-active heteroleptic pianostool $\quad \mathrm{Ru}(\mathrm{II}), \quad \mathrm{Rh}(\mathrm{III}), \quad$ and $\operatorname{Ir}(\mathrm{III})$ complexes containing 4-(2methoxypyridyl)phenyldipyrromethene. Inorg Chem 2013, 52 (7), 3687-98. 
86. Sheng, X.; Guo, X.; Lu, X. M.; Lu, G. Y.; Shao, Y.; Liu, F.; Xu, Q., DNA binding, cleavage, and cytotoxic activity of the preorganized dinuclear zinc(II) complex of triazacyclononane derivatives. Bioconjug Chem 2008, 19 (2), 490-8.

87. Sissi, C.; Mancin, F.; Palumbo, M.; Scrimin, P.; Tecilla, P.; Tonellato, U., DNA phosphodiester bond hydrolysis mediated by $\mathrm{Cu}$ (II) and $\mathrm{Zn}$ (II) complexes of 1,3,5,triamino-cyclohexane derivatives. Nucleosides Nucleotides Nucleic Acids 2000, 19 (8), 1265-71.

88. Melvin, M. S.; Tomlinson, J. T.; Saluta, G. R.; Kucera, G. L.; Lindquist, N.; Manderville, R. A., Double-Strand DNA Cleavage by Copper-Prodigiosin. Journal of the American Chemical Society 2000, 122 (26), 6333-6334.

89. Boger, D. L.; Patel, M., Total synthesis of prodigiosin, prodigiosene, and desmethoxyprodigiosin: Diels-Alder reactions of heterocyclic azadienes and development of an effective palladium(II)-promoted 2,2'-bipyrrole coupling procedure. The Journal of Organic Chemistry 1988, 53 (7), 1405-1415.

90. D'Alessio, R.; Bargiotti, A.; Carlini, O.; Colotta, F.; Ferrari, M.; Gnocchi, P.; Isetta, A.; Mongelli, N.; Motta, P.; Rossi, A.; Rossi, M.; Tibolla, M.; Vanotti, E., Synthesis and immunosuppressive activity of novel prodigiosin derivatives. In J Med Chem, United States, 2000; Vol. 43, pp 2557-65. 